\title{
EVALUATION OF EFFECTIVE WIDTH AND DISTRIBUTION FACTORS FOR GFRP BRIDGE DECKS SUPPORTED ON STEEL GIRDERS
}

\author{
by \\ Jonathan Moses
}

B.S.C.E., University of Pittsburgh, 2004

Submitted to the Graduate Faculty of

The School of Engineering in partial fulfillment

of the requirements for the degree of

Master of Science in Civil Engineering

University of Pittsburgh 


\section{UNIVERSITY OF PITTSBURGH \\ SCHOOL OF ENGINEERING}

This thesis was presented

by

Jonathan Moses

It was defended on

September 16, 2005

and approved by

Thesis Advisor: Dr. Kent A. Harries, Assistant Professor, Dept. of Civil \& Environmental Engineering
Committee Member: Dr. Christopher Earls, Chairman, Associate Professor \& William Kepler Whiteford Faculty Fellow, Dept. of Civil \& Environmental Engineering

Committee Member: Dr. Amir Koubaa, Academic Coordinator, Department of Civil \& Environmental Engineering 


\title{
ABSTRACT \\ EVALUATION OF EFFECTIVE WIDTH AND DISTRIBUTION FACTORS FOR GFRP BRIDGE DECKS SUPPORTED ON STEEL GIRDERS
}

\author{
Jonathan Moses, M.S. \\ University of Pittsburgh, 2005
}

Glass fiber reinforced polymer (GFRP) bridge deck systems offer an attractive alternative to concrete decks, particularly for bridge rehabilitation projects. Current design practice treats GFRP deck systems in a manner similar to concrete decks. The results of this study, however, indicate that this may result in non-conservative design values for the bridge girders. Results from a number of in situ load tests of three steel girder bridges having the same (GFRP) deck system are used to determine the degree of composite action that may be developed and the transverse distribution of wheel loads that may be assumed for such structures. Results indicate that appropriately conservative design values may be found by assuming no composite action between GFRP deck and steel girder and using the lever rule to determine transverse load distribution. When used to replace an existing concrete deck, the lighter GFRP deck will result in lower total loads applied to the bridge structure, although, due to the decreased effective width and increased distribution factors, local flange stresses and particularly the live load-induced stress range is likely to be increased. Thus, existing fatigue-prone details may become a concern and require attention in design. 


\section{TABLE OF CONTENTS}

1.0 INTODUCTION AND LITERATURE REVIEW .................................................. 1

1.1 REINFORCED CONCRETE BRIDGE DECKS ............................................... 3

1.2 FIBER REINFORCED POLYMER BRIDGE DECKS …....................................... 3

1.2.1 Existing GFRP Bridge Decks in Use .................................................... 5

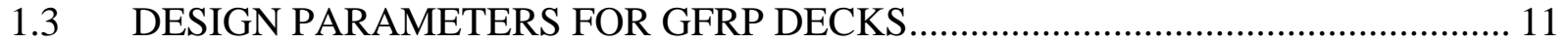

1.3.1 Effective Width of Deck .................................................................... 11

1.3.1.1 Calculating Effective Width from In-situ Tests............................................ 12

1.3.2 Engaging Effective Deck Width with Shear Connectors................................. 14

1.3.2.1 Push-off Tests to Determine Stud Capacity ................................................... 15

1.3.2.2 Engaging Effective Deck Width with Adhesively Bonded Deck Systems....... 19

1.3.3 Moment Distribution Factors............................................................... 20

1.3.3.1 Calculating Moment Distribution Factors from In-situ Tests.......................... 22

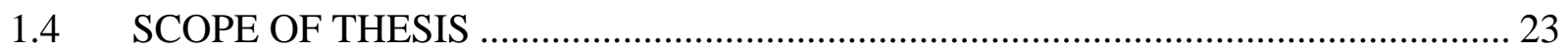

2.0 DESCRIPTIONS OF BRIDGES REPORTED IN THIS STUDY ............................... 24

2.1 TYPICAL GFRP DECK PANEL INSTALLATION ............................................. 26

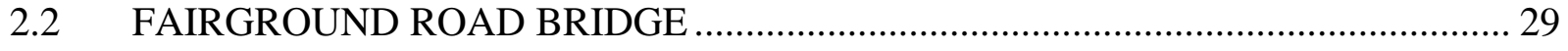

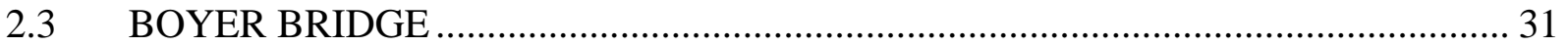

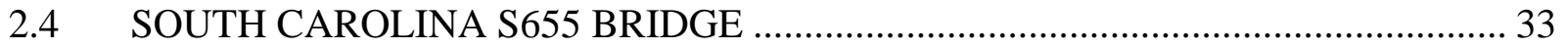

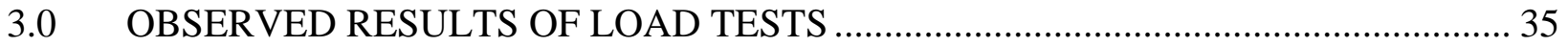




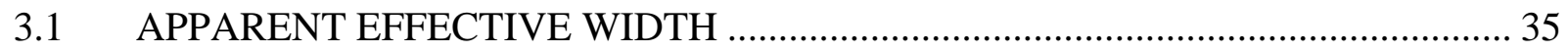

3.2 MOMENT DISTRIBUTION FACTORS FROM IN-SITU TESTS ………………....... 38

3.3 IMPLICATIONS FOR NEW CONSTRUCTION USING GFRP DECKS .................. 41

3.3.1 Composite Behavior........................................................................................... 41

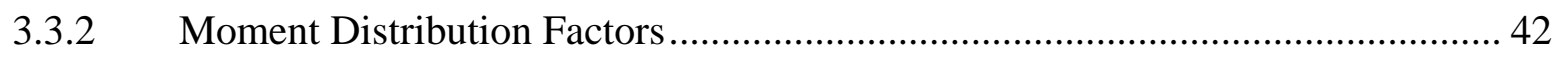

3.4 IMPLICATIONS FOR REPLACING CONCRETE DECKS WITH GFRP DECKS . 42

4.0 ILLUSTRATIVE EXAMPLE - SUPERSTRUCTURE STRESSES................................44

4.1 PROTOTYPE BRIDGE SECTIONAL PROPERTIES................................................. 44

4.1.1 Plastic Moment Calculation for Composite GFRP Case ...................................... 49

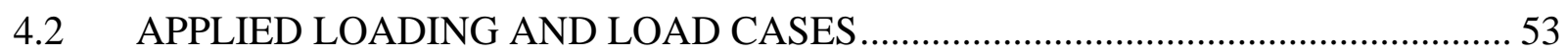

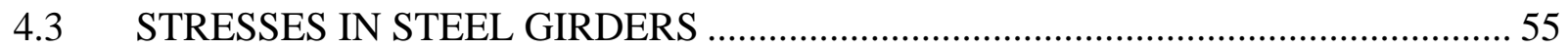

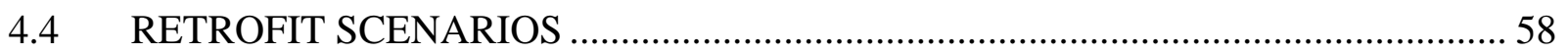

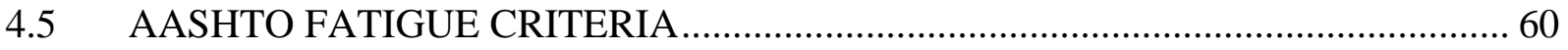

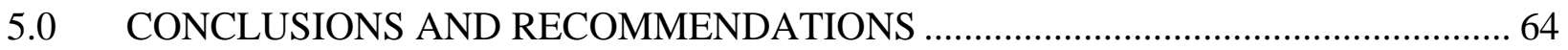

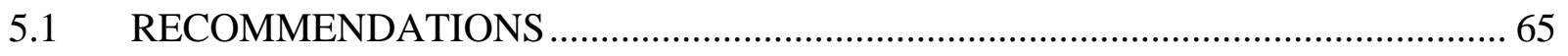

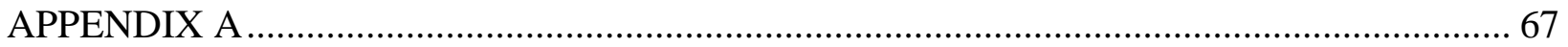

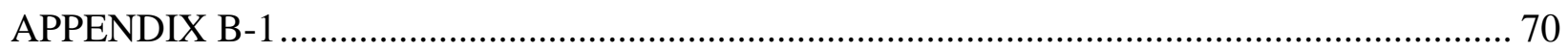

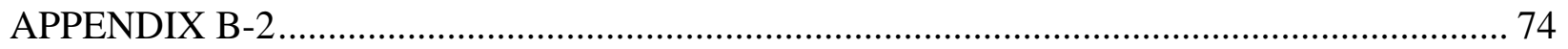

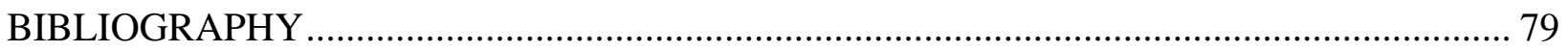




\section{LIST OF TABLES}

Table 1-1: Existing Bridges with GFRP Decks ............................................................... 6

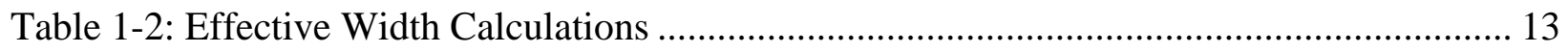

Table 1-3: Shear Stud Capacities for Various Tests ............................................................. 18

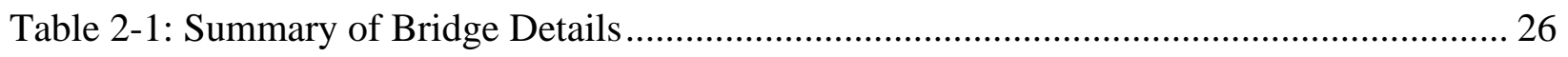

Table 3-1: Comparison of AASHTO and Observed Effective Width Values ............................ 36

Table 3-2: Comparison of AASHTO and Observed Moment Distribution Factor Values........... 39

Table 4-1: Material and Member Properties ........................................................................ 46

Table 4-2: Plastic Moment Capacity Calculation ............................................................. 52

Table 4-3: Design Loading and Moments (see Appendix B-2 for details)............................... 54

Table 4-4: Calculated Stress Ranges - STRENGTH I ...................................................... 56

Table 4-5: Calculated Stress Ranges - SERVICE I ....................................................... 56

Table 4-6: Calculated Stress Ranges - FATIGUE ......................................................... 56

Table 4-7: Ratios of Post-Retrofit Stresses to Pre-Retrofit Stresses ........................................ 59

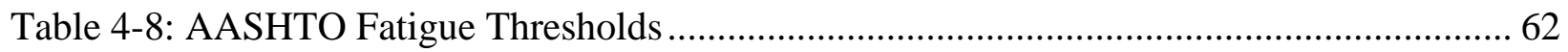




\section{LIST OF FIGURES}

Figure 1-1: Schematic of DuraSpan Deck Panel (MMC) ........................................................ 5

Figure 1-2: Cross-Section of GFRP Composite Section.................................................... 13

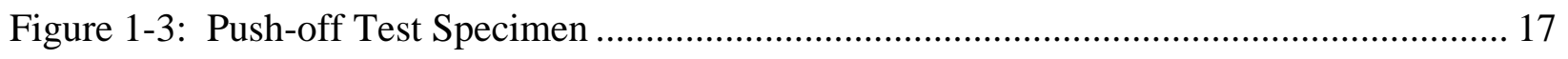

Figure 1-4: Push-off Test Specimen in Load Frame (Yulismana 2005).................................. 17

Figure 2-1: Transverse Section GFRP Deck Geometry and Dimensions................................ 25

Figure 2-2: Installation of GFRP deck panels (Boyer Bridge) …......................................... 28

Figure 2-3: Fairground Road Bridge........................................................................... 30

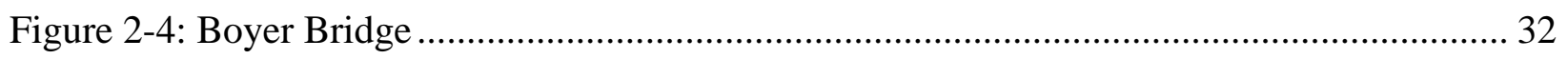

Figure 2-5: South Carolina SC655 Bridge...................................................................... 34

Figure 4-1: Cross-section of Composite Beam (Case 1) ................................................... 48

Figure 4-2: Cross-section of Composite Beam (Case 3) .................................................. 48

Figure 4-3: Loading Condition of Top Face Plate .............................................................. 50

Figure 4-4: Determination of Plastic Section................................................................ 51 


\section{ACKNOWLEDGEMENTS}

I would like to thank Dr. Earls for believing in me and giving me the opportunity to do the research and the subsequent thesis. I would like to thank Dr. Harries for the many hours of review, comments, and guidance provided me throughout and for giving me the necessary push to see this thesis to conclusion. I would also like to thank Dr. Koubaa for being on my committee and assisting me with the process. Finally, I would like to thank Joe Yulismana for teaching me everything I know about composites and testing in the lab. 


\subsection{INTODUCTION AND LITERATURE REVIEW}

The deteriorating state of the Nation's bridge infrastructure is well documented. Fewer resources are available to maintain and repair a growing list of deteriorated structures. Deterioration of bridge structures may result from age, exposure to adverse environments (particularly the use of de-icing salts), increasing traffic volumes and loading, or specific extreme events such as truck impacts. To address the issue of deteriorating structures, new cost effective technology which can extend the service life of such structures is necessary. In recent years, high-performance fiber reinforced polymer (FRP) composite materials have been identified as excellent candidates for rehabilitating aging bridge structures.

According to data from the National Bridge Inventory (NBI 2003), of the nation's approximately 615,000 bridges, over $26 \%$ were either not structurally sufficient or functionally

obsolete. These numbers were significantly worse for Pennsylvania, with an estimated $42 \%$ of the state's approximately 22,000 bridges being deemed either not structurally sufficient or functionally obsolete. A major cause of the structural deficiency of existing bridges is excessive deterioration of conventional concrete decks. Deterioration is often worse in northern states where large amounts of de-icing salt are applied to the deck surfaces of bridges during the winter months. It has been estimated (FHWA 2004) that more than 88,000,000 $\mathrm{m}^{2}$ (approximately 1 billion square feet) of bridge deck is currently in need of replacement at an estimated cost of over $\$ 30$ billion. Additionally, 19\% of the nation’s bridges are either posted for load or in need of posting (NBI 2003). 
There are a variety of different deck types to choose from at present. Traditionally, reinforced concrete decks are used in most bridge structures. Another type of deck that has been in use for more than 60 years is the concrete filled steel grid deck. More recent innovations aimed at reducing deck weight include orthotropic steel deck systems and GFRP bridge deck panels, which are both becoming more commonly used for bridge deck replacement.

The use of GFRP bridge deck elements has been introduced and demonstrated as a viable means of both deck replacement and new deck construction. Since 1998, 83 bridges in the United States have been constructed or had their existing decks replaced with GFRP decks (Hooks and O’Connor 2004). GFRP decks are attractive because of their minimal installation time, high strength-to-weight ratios, and excellent tolerance to frost and de-icing salts. Their light weight, and thus reduced dead load, is particularly attractive for rehabilitating posted structures since the replacement of heavy conventional concrete decking with lighter weight GFRP decking may translate to additional live load carrying capacity for the bridge system.

Curiously, despite this latter advantage, most of the bridges currently employing GFRP decks in their designs are new construction as opposed to rehabilitation applications. Using GFRP deck panels in a new design may not be as practical as using them for rehabilitation projects. The deck panels themselves are initially more expensive than their equivalent concrete slab counterparts and there is not likely to be a great savings to be had from the reduced dead load. The installation time, however, can be as little as one working day for a relatively short span bridge. This is a significant time savings over placing a concrete deck and may warrant the selection of a GFRP deck for new construction in some circumstances.

For rehabilitation, however, the reduced dead load of a GFRP deck may represent a significant advantage possibly allowing load posting to be removed or an increase in the bridge 
rating to be made. For example, the deck system reported in this work weighs approximately one fifth of what a comparable concrete deck would weigh. Similarly, for historic bridge structures, the reduced deck load may permit increased load rating without altering the original state of the bridge. The rapid installation of a GFRP deck also reduces bridge closure time for a rehabilitation project.

\subsection{REINFORCED CONCRETE BRIDGE DECKS}

Conventional concrete bridge deck design is largely prescriptive; guided by general proportions as promulgated by the AASHTO (1996 and 2004) specifications. Deck thickness and reinforcing details are selected based on longitudinal girder spacing. Strength and serviceability of bridge systems having concrete decks have been established by heuristic and theoretical means and the adequacy of such approaches have been borne out by engineering experience as well as experimentally. The spatial nature of concrete deck systems allows the deck to transmit loads laterally to the primary longitudinal girders while composite action between the deck and the underlying girders may also be developed to permit the deck to assist in resisting the longitudinal flexure in the span. These characteristics of a bridge deck are quantified in a design context through the definition of the moment distribution factor and the effective width, respectively. These characteristics will be discussed further below in relation to both new construction and rehabilitation.

\subsection{FIBER REINFORCED POLYMER BRIDGE DECKS}

Glass fiber reinforced polymer (GFRP) composite bridge deck systems are beginning to gain acceptance as light weight and durable alternatives to concrete decks (Black 2003). 
Although many existing demonstration projects are based on new bridges, (Hooks and O’Connor 2004), GFRP decks hold their greatest promise as a method of deck replacement for older structures. GFRP bridge decks capable of replacing 200 to $250 \mathrm{~mm}$ (8 to $10 \mathrm{in}$.) thick reinforced concrete decks (weighing 4.8 to $6.0 \mathrm{kPa}$ (100 to $125 \mathrm{psf}$ )) typically weigh about $0.96 \mathrm{kPa}$ (20 psf) without a wearing surface, representing a significant savings in the dead load of the superstructure.

Although there are a variety of proprietary GFRP bridge deck systems that have been proposed and demonstrated, this work focuses on those systems designed to span transversely between longitudinal bridge girders and carry traffic loads in a manner similar to a "one way" concrete deck. Such GFRP deck systems have taken two fundamental forms (Turner 2003):

1. A series of closed-shape pultruded GFRP tubes that are sandwiched between top and bottom face plates. The tubes and face plate components are assembled using a structural adhesive. (examples include Crocker et al. 2002 and Zhou et al. 2002). A variation on this form using an arrangement of perpendicular tubes and no face plates is presented by Chandrashekhara and Nanni (2000).

2. A series of interlocking pultruded shapes which include both face plates and web elements (examples include Motley et al. 2002 and GangaRao et al. 1999). Such systems are generally more versatile and have better final product quality control than adhesively assembled tubes. An example of this type of deck is the Martin Marietta Composites DuraSpan Deck Panel considered in this work (see Figure 1-1). 


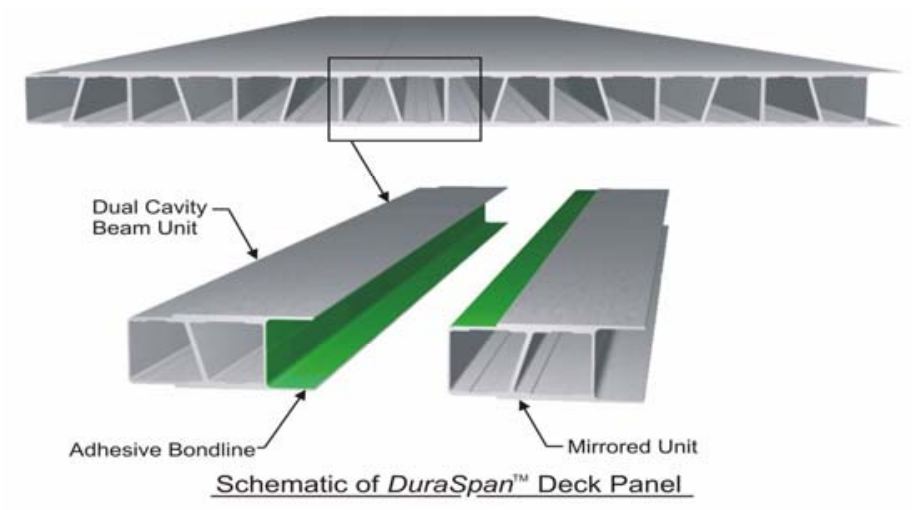

Figure 1-1: Schematic of DuraSpan Deck Panel (MMC)

\subsubsection{Existing GFRP Bridge Decks in Use}

According to the American Composites Manufacturers Association (ACMA), there are currently 83 existing road bridges in the United States having GFRP decks (see Table 1-1). The geometry and loading conditions of these structures vary considerably. The bridges of interest to the current study are slab-on-girder highway bridges carrying at least two lanes of traffic. This corresponds to a roadway width of $5.5 \mathrm{~m}$ (18.0 ft.) or greater, or an overall deck width of approx. $6.5 \mathrm{~m}$ (21.3 ft.) or greater. The greater number accounts for parapets or guide rail attached to the deck. There are 68 bridges that satisfy these criteria. Of these, 38 are GFRP deck-on-steel girder structures. Additionally, there are some GFRP deck-on-prestressed concrete girder structures and three with GFRP box beam superstructures and two with GFRP girder superstructures. In the girder-supported structures, the girder spacing over which the GFRP deck spans ranges from 800 $\mathrm{mm}$ (31.5 in.) to $2840 \mathrm{~mm}$ (112 in.). Initially, there were a number of manufacturers of GFRP bridge deck systems. The two surviving major suppliers in the U.S. are Kansas Structural Composites and Martin Marietta Composites (MMC). Twenty-five of the bridge decks cited were fabricated by MMC, the same manufacturer as the deck system discussed in this study. 
Table 1-1: Existing Bridges with GFRP Decks

\begin{tabular}{|c|c|c|c|c|c|c|c|}
\hline State & Bridge Name & Year & Deck Manufacturer & Length, m & Width, m & Girder Type & $\begin{array}{c}\text { Support } \\
\text { Spacing, m }\end{array}$ \\
\hline CA & UCSD Road Test Panels & 1996 & MMC DuraSpan & 2.44 & 4.57 & & \\
\hline CA & King's Stormwater Channel & 2000 & MMC DuraSpan & 20.1 & 13.4 & $\begin{array}{c}\text { Carbon w/Concrete } \\
\text { Fill } \\
\end{array}$ & 2.3 \\
\hline CA & Schuyler Hein Lift Bridge & 2001 & MMC DuraSpan & 12.8 & 11 & Steel (truss) & 1.2 \\
\hline $\mathrm{DE}$ & Magazine Ditch Bridge & 1997 & Hardcore Composites & 21.3 & 7.6 & $\begin{array}{l}\text { Prestressed } \\
\text { Concrete }\end{array}$ & \\
\hline $\mathrm{DE}$ & Bridge 1-351 & 1998 & Hardcore Composites & 9 & 8 & Self Supporting & \\
\hline $\mathrm{DE}$ & Muddy Run Bridge & 1998 & Hardcore Composites & 9.8 & 7.9 & Self Supporting & \\
\hline $\mathrm{DE}$ & Old Mill Creek Bridge & 1999 & Hardcore Composites & 11.9 & 5.2 & Steel & 0.9 \\
\hline $\mathrm{DE}$ & Greensbranch Trail Bridge & 1999 & Hardcore Composites & 6.4 & 3.7 & Self Supporting & \\
\hline IA & 53rd Ave. Bridge 2 & 2001 & MMC DuraSpan & 14.3 & 29.26 & & \\
\hline IA & Crow Creek Bridge & 2001 & MMC DuraSpan & 14.3 & 29.9 & $\begin{array}{c}\text { Prestressed } \\
\text { Concrete } \\
\end{array}$ & \\
\hline ID & INEEL Bridge & 1997 & MMC DuraSpan & 9.1 & 5.5 & GFRP Box Beams & \\
\hline IL & South Fayette St. Bridge & 2001 & MMC DuraSpan & 19.2 & 11 & Steel & 1.47 \\
\hline KS & No Name Creek Bridge & 1996 & $\begin{array}{l}\text { Kansas Structural } \\
\text { Composites }\end{array}$ & 7.1 & 8.5 & Steel/freespan & 2 \\
\hline KS & Highway 126-B Bridge & 1999 & $\begin{array}{l}\text { Kansas Structural } \\
\text { Composites }\end{array}$ & 13.7 & 9.8 & Steel & \\
\hline KS & Highway 126-A Bridge & 1999 & $\begin{array}{l}\text { Kansas Structural } \\
\text { Composites }\end{array}$ & 13.7 & 9.8 & Steel & \\
\hline KS & Kansas Detour Bridge \#1 & 2003 & $\begin{array}{l}\text { Kansas Structural } \\
\text { Composites }\end{array}$ & 18.3 & 9.14 & Steel & \\
\hline KS & Kansas Detour Bridge \#2 & 2003 & $\begin{array}{l}\text { Kansas Structural } \\
\text { Composites }\end{array}$ & 18.3 & 9.14 & Steel & \\
\hline MD & Washington Schoolhouse Rd. Bridge & 1997 & Hardcore Composites & 5.3 & 7.6 & Self Supporting & \\
\hline
\end{tabular}


Table 1-1 (continued)

\begin{tabular}{|c|c|c|c|c|c|c|c|}
\hline State & Bridge Name & Year & Deck Manufacturer & Length, m & Width, m & Girder Type & $\begin{array}{c}\text { Support } \\
\text { Spacing, m }\end{array}$ \\
\hline MD & Wheatley Rd. Bridge & 2000 & Hardcore Composites & 10.36 & 7.3 & Self Supporting & \\
\hline MD & MD 24 Over Deer Creek Bridge & 2001 & MMC DuraSpan & 39 & 9.8 & Steel & 1.2 \\
\hline MD & Snouffer School Rd. Bridge & 2001 & Hardcore Composites & 8.84 & 10.06 & Self Supporting & \\
\hline $\mathrm{ME}$ & Milbridge Municipal Pier Bridge & 2000 & Univ. of Maine & 53.34 & 4.88 & & \\
\hline $\mathrm{ME}$ & Skidmore Bridge & 2000 & Kenway Corp. & 18.9 & 7.01 & Steel & \\
\hline MI & Bridge St. Over Rouge River & 2001 & Mitsubishi Chemical & 60.35 & 9.14 & & \\
\hline MO & St. John's Street Bridge & 2000 & $\begin{array}{l}\text { Kansas Structural } \\
\text { Composites }\end{array}$ & 8.23 & 7.92 & Steel & \\
\hline MO & St. Francis Street Bridge & 2000 & $\begin{array}{l}\text { Kansas Structural } \\
\text { Composites }\end{array}$ & 7.92 & 8.53 & Freespan & \\
\hline $\mathrm{NC}$ & Service Route 1627 Bridge Over Mill Creek & 2001 & MMC DuraSpan & 12.2 & 7.62 & Steel & 1.19 \\
\hline NY & Route 248 Bridge Over Bennetts Creek & 1998 & Hardcore Composites & 7.62 & 10.1 & Self Supporting & 7.62 \\
\hline NY & Route 367 Bridge Over Bentley Creek & 1999 & Hardcore Composites & 42.7 & 7.6 & Steel Floor Beam & 4.3 \\
\hline NY & Cayuta Creek Bridge & 2000 & Hardcore Composites & 39.3 & 8.8 & Steel & 1.8 \\
\hline NY & South Broad St. Bridge & 2000 & Hardcore Composites & 36.6 & 8.8 & Steel & \\
\hline NY & SR 418 Over Schroon River Bridge & 2000 & MMC DuraSpan & 48.8 & 7.9 & $\begin{array}{l}\text { Steel - Floorbeams } \\
\quad \& \text { Stringers } \\
\end{array}$ & 1.2 \\
\hline NY & $\begin{array}{l}\text { Triphammer Rd. Bridge Over Conesus Lake } \\
\text { Outlet }\end{array}$ & 2001 & Hardcore Composites & 12.2 & 10.1 & GFRP Box Beams & \\
\hline NY & Route 36 Over Tributary to Troups Creek & 2001 & $\begin{array}{l}\text { Kansas Structural } \\
\text { Composites }\end{array}$ & 9.75 & 11.28 & & \\
\hline
\end{tabular}


Table 1-1 (continued)

\begin{tabular}{|c|c|c|c|c|c|c|c|}
\hline State & Bridge Name & Year & Deck Manufacturer & Length, m & Width, m & Girder Type & $\begin{array}{c}\text { Support } \\
\text { Spacing, m }\end{array}$ \\
\hline NY & County Rd. 153 & 2002 & Hardcore Composites & 16.5 & 8.2 & & \\
\hline $\mathrm{OH}$ & Smith Creek Bridge (TECH-21) & 1997 & MMC DuraSpan & 10.1 & 7.3 & GFRP Box Beams & 2.4 \\
\hline $\mathrm{OH}$ & Shawnee Creek Bridge & 1997 & $\begin{array}{l}\text { Creative Pultrusions } \\
\text { Superdeck }\end{array}$ & 7.3 & 3.66 & $\begin{array}{c}\text { Railway Bridge } \\
\text { Beams }\end{array}$ & \\
\hline $\mathrm{OH}$ & Woodington Run Bridge & 1999 & MMC DuraSpan & 15.2 & 14 & Galvanized Steel & 2.5 \\
\hline $\mathrm{OH}$ & Salem Bridge (1) & 1999 & $\begin{array}{l}\text { Creative Pultrusions } \\
\text { Superdeck }\end{array}$ & 51.2 & 15.24 & Steel & 2.7 \\
\hline $\mathrm{OH}$ & Salem Bridge (2) & 1999 & Hardcore Composites & 51.2 & 15.24 & Steel & 2.7 \\
\hline $\mathrm{OH}$ & Salem Bridge (3) & 1999 & $\begin{array}{l}\text { Infrastructure Composites } \\
\text { Int'l }\end{array}$ & 17.68 & 15.24 & Steel & 2.7 \\
\hline $\mathrm{OH}$ & Sintz Rd. Bridge & 2000 & Hardcore Composites & 18.9 & 9.14 & Steel & \\
\hline $\mathrm{OH}$ & Westbrook Road Bridge Over Dry Run Creek & 2000 & Hardcore Composites & 10.36 & 10.1 & Self Supporting & \\
\hline $\mathrm{OH}$ & Highway 14 Over Elliot Run & 2000 & Hardcore Composites & 11.9 & 7.9 & Steel & \\
\hline $\mathrm{OH}$ & Five Mile Road Bridge \#0171 & 2000 & Hardcore Composites & 13.4 & 8.5 & AASHTO Type II & 2.2 \\
\hline $\mathrm{OH}$ & Five Mile Road Bridge \#0087 & 2001 & Hardcore Composites & 14.3 & 9.14 & AASHTO Type II & 2.2 \\
\hline $\mathrm{OH}$ & Five Mile Road Bridge \#0071 & 2001 & Hardcore Composites & 13.1 & 9.14 & AASHTO Type II & 2.2 \\
\hline $\mathrm{OH}$ & Shaffer Road Bridge & 2001 & Hardcore Composites & 53.3 & 5.2 & Steel & \\
\hline $\mathrm{OH}$ & Stelzer Road Bridge & 2001 & $\begin{array}{l}\text { Fiber Reinforced Systems } \\
\text { Inc. }\end{array}$ & 118 & 10.7 & & 2.1 \\
\hline $\mathrm{OH}$ & Tyler Road Bridge Over Bokes Creek & 2001 & $\begin{array}{l}\text { Fiber Reinforced Systems } \\
\text { Inc. }\end{array}$ & 36.6 & 6.1 & Steel & \\
\hline $\mathrm{OH}$ & Fairground Road Bridge & 2002 & MMC DuraSpan & 67.4 & 9.75 & Steel & 2.84 \\
\hline
\end{tabular}


Table 1-1 (continued)

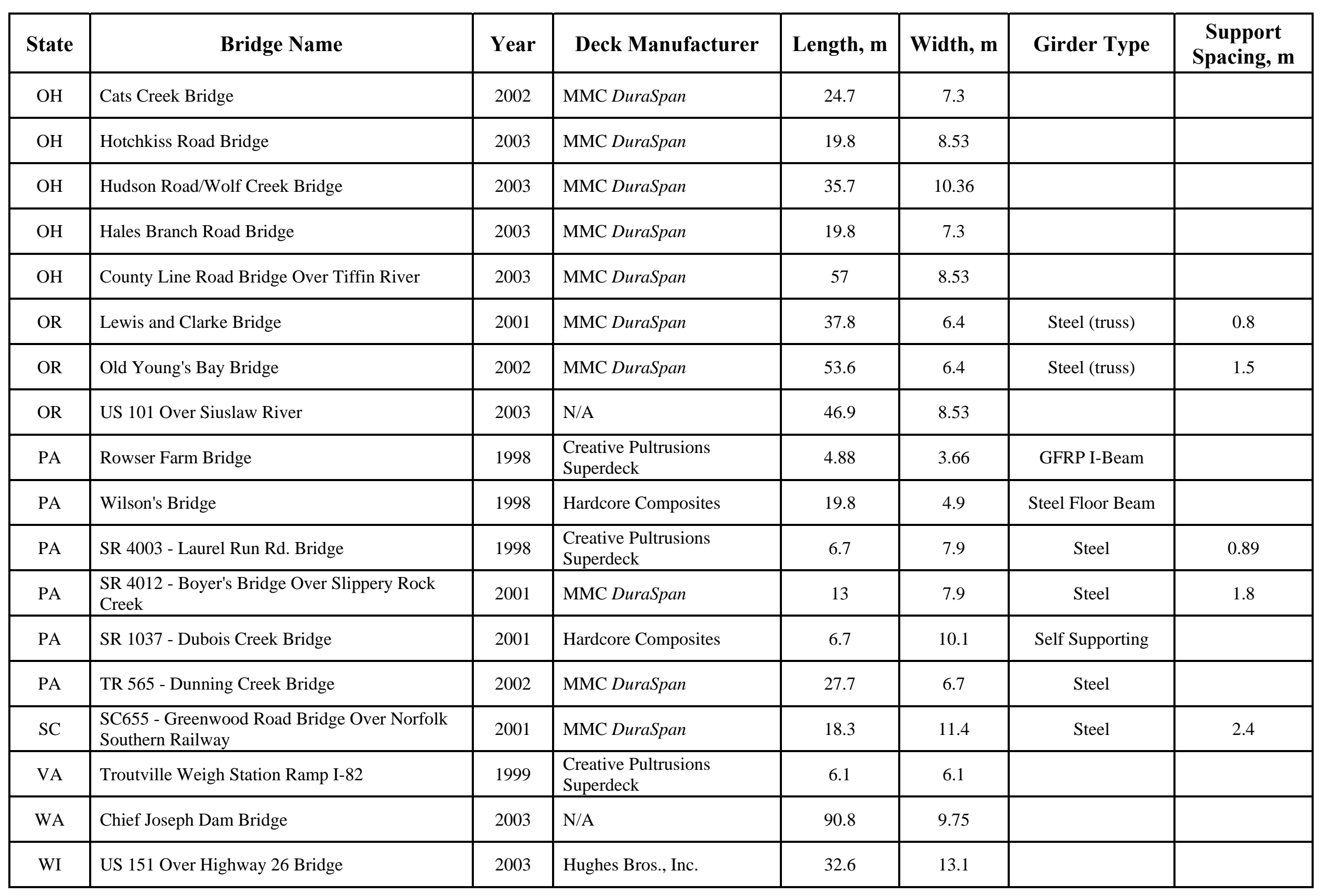


Table 1-1 (continued)

\begin{tabular}{|c|c|c|c|c|c|c|c|}
\hline State & Bridge Name & Year & Deck Manufacturer & Length, $\mathrm{m}$ & Width, m & Girder Type & $\begin{array}{c}\text { Support } \\
\text { Spacing, m }\end{array}$ \\
\hline WI & US 151 Over Highway 26 Bridge & 2003 & Diversified Composites & 65.2 & 11.9 & & \\
\hline WV & Wickwire Run Bridge & 1997 & $\begin{array}{l}\text { Creative Pultrusions } \\
\text { Superdeck }\end{array}$ & 9.1 & 6.7 & Steel & 1.8 \\
\hline WV & Laurel Lick Bridge & 1997 & $\begin{array}{l}\text { Creative Pultrusions } \\
\text { Superdeck }\end{array}$ & 6.1 & 4.88 & GFRP I-Beam & \\
\hline WV & Market Street Bridge & 2000 & $\begin{array}{l}\text { Creative Pultrusions } \\
\text { Superdeck }\end{array}$ & 54.9 & 17.1 & Steel & 2.6 \\
\hline WV & Hanover Bridge & 2001 & $\begin{array}{l}\text { Kansas Structural } \\
\text { Composites }\end{array}$ & 36.6 & 8.5 & Steel & 1.3 \\
\hline WV & Boy Scout Camp Bridge & 2001 & Hardcore Composites & 9.4 & 7.9 & Steel & 1.1 \\
\hline WV & Montrose Bridge & 2001 & Hardcore Composites & 11.9 & 8.5 & Steel & 1.4 \\
\hline WV & West Buckeye Bridge & 2001 & $\begin{array}{l}\text { Kansas Structural } \\
\text { Composites }\end{array}$ & 45.1 & 11 & Steel & \\
\hline WV & Katty Truss Bridge & 2002 & $\begin{array}{l}\text { Creative Pultrusions } \\
\text { Superdeck }\end{array}$ & 27.4 & 4.3 & Steel & 1.8 \\
\hline WV & La Chein Bridge & 2003 & Bedford Reinforced Plastics & 9.75 & 7.3 & Steel & 1.3 \\
\hline WV & Howell's Mill Bridge & 2003 & MMC DuraSpan & 74.7 & 10.1 & Steel & 2.1 \\
\hline \multirow[t]{2}{*}{ WV } & Goat Farm Bridge & 2003 & $\begin{array}{l}\text { Kansas Structural } \\
\text { Composites }\end{array}$ & 12.2 & 4.6 & Steel & 1.2 \\
\hline & \multicolumn{7}{|c|}{$\begin{array}{l}\text { The information contained in this table was collected from a variety of sources. Most data however, may be found in the following } \\
\text { references: http://www.mdacomposites.org/mda/Bridge_Report_VEH.htm, West Virginia University (2001), Martin Marietta } \\
\text { Composites (2001), Hodgson et al. (2002) and FHWA (2002). }\end{array}$} \\
\hline
\end{tabular}




\subsection{DESIGN PARAMETERS FOR GFRP DECKS}

There are several important differences in behavior between conventional reinforced concrete bridge decks and GFRP bridge decks. GFRP bridge decks do not act in a fully composite manner with the underlying girders, as it is assumed concrete decks may. Thus, the effective width is an important parameter to consider in deck replacements with GFRP deck panels. Another important parameter to consider is the moment distribution factor for the bridge. The moment distribution factor (DF) is a measure of the proportion of the live load that each girder must be designed to resist. There is a different distribution factor for interior and exterior girders.

\subsubsection{Effective Width of Deck}

In a composite deck-girder system, the effective width of the deck is the portion of the deck assumed to be contributing to the flexural capacity of the longitudinal girder through the development of a uniform longitudinal stress field. Such an approach is adopted as a simplification allowing for the neglect of the actual "shear lag" in the deck plate during flexure. The deck is engaged by providing interfacial continuity between the deck and girders through the use of shear connectors. The width of deck that may be engaged in flexure must be evaluated in order to optimize the design of the longitudinal girder system. In new construction using GFRP decks, many demonstration projects have not relied on composite action between the deck and girders. Since these are largely demonstration projects, the girders have been designed to permit the eventual replacement of the demonstration GFRP deck with a heavier conventional concrete deck, often assuming that no composite behavior will be available (Turner et al. 2004). Nonetheless, shear connectors have been provided in all existing applications and a measure of composite action under service loads is therefore achieved (Keelor et al. 2004). 
For interior steel girders having a composite concrete deck, the effective concrete flange width contributing to the flexural capacity of the girder is prescribed (AASHTO (2004) Clause 4.6.2.6.1) to be the lesser of:

1. one quarter of the effective span length;

2. 12 times the depth of the concrete deck plus one half the width of the top flange of the girder; or,

3. the average spacing of adjacent beams (denoted S).

Differences between the effective width that may be engaged between concrete and replacement GFRP decks may be a critical consideration in deck replacement. If an existing bridge behaves in a composite manner, the replacement deck must also permit this behavior; otherwise girder stresses due to live loads will increase significantly. While it is true that dead load stresses may be significantly reduced in the case of a GFRP deck, this does not affect the live load induced stress range which may also affect fatigue-sensitive details.

\subsubsection{Calculating Effective Width from In-situ Tests}

The calculations for effective width in this study are based on fundamental mechanics and the assumption that plane sections remain plane. The calculations assumed fully composite action between the steel stringers and the GFRP deck, although it is apparent from the data that the GFRP deck is not acting in a fully composite manner.

The effective width of deck is calculated from a plane sections analysis of the composite girder calculating the location of the neutral axis based on in situ girder strains and applying girder and deck material properties. For a composite section, the neutral axis is located using 
simple mechanics by performing transformed section calculations. In the case presented, the effective width, $b_{\text {eff, }}$ is unknown and the neutral axis location, $y$, is determined from in situ data. Using the composite section properties, the apparent effective width of the section is calculated as shown in Table 1-2 and Figure 1-2.

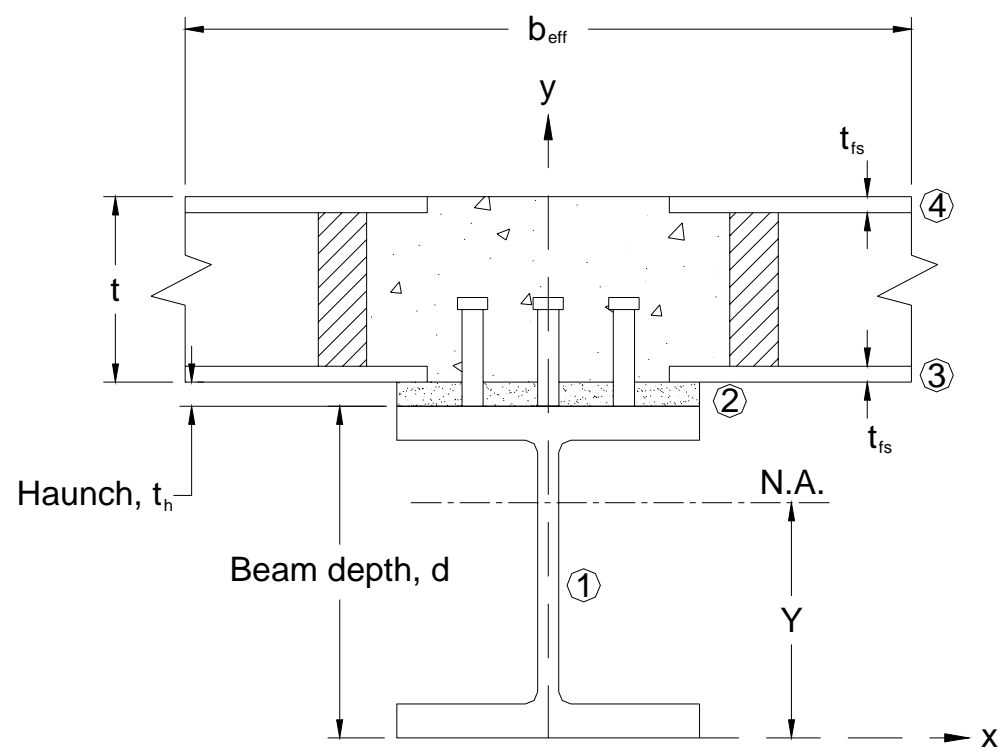

Figure 1-2: Cross-Section of GFRP Composite Section

Table 1-2: Effective Width Calculations

\begin{tabular}{|c|c|c|c|}
\hline Element & $\begin{array}{c}\text { Area, } \mathbf{A}_{\mathbf{n}} \\
\text { (Transformed) }\end{array}$ & $\begin{array}{c}\text { Centroidal axis } \\
\text { location, } \mathbf{y}_{\mathbf{n}}\end{array}$ & $\mathbf{A}_{\mathbf{n}} \mathbf{y}_{\mathbf{n}}$ \\
\hline $\begin{array}{c}1 \\
\text { girder }\end{array}$ & $\mathrm{A}_{1}$ & $\mathrm{y}_{1}=\mathrm{d} / 2$ & $\mathrm{~A}_{1} * \mathrm{y}_{1}$ \\
\hline $\begin{array}{c}2 \\
\text { haunch }\end{array}$ & $\left(\mathrm{E}_{\mathrm{c}} / \mathrm{E}_{\mathrm{s}}\right) \mathrm{A}_{2}$ & $\mathrm{y}_{2}=\mathrm{d}+\mathrm{t}_{\mathrm{h}} / 2$ & $\left(\mathrm{E}_{\mathrm{c}} / \mathrm{E}_{\mathrm{s}}\right) \mathrm{A}_{2}{ }^{*} \mathrm{y}_{2}$ \\
\hline $\begin{array}{c}3 \\
\text { bot. face sheet }\end{array}$ & $\left(\mathrm{E}_{\mathrm{frp}} / \mathrm{E}_{\mathrm{s}}\right) \mathrm{t}_{\mathrm{fs}} * \mathrm{~b}_{\mathrm{eff}}$ & $\mathrm{y}_{3}=\mathrm{d}+\mathrm{t}_{\mathrm{h}}+\mathrm{t}_{\mathrm{fs}} / 2$ & $\mathrm{y}_{3} *\left(\mathrm{E}_{\mathrm{frp}} / \mathrm{E}_{\mathrm{s}}\right) * \mathrm{t}_{\mathrm{fs}} * \mathrm{~b}_{\mathrm{eff}}$ \\
\hline $\begin{array}{c}4 \\
\text { top face sheet }\end{array}$ & $\left(\mathrm{E}_{\mathrm{frp}} / \mathrm{E}_{\mathrm{s}}\right) \mathrm{t}_{\mathrm{fs}} * \mathrm{~b}_{\mathrm{eff}}$ & $\mathrm{y}_{4}=\mathrm{d}+\mathrm{t}_{\mathrm{h}}+\mathrm{t}-\mathrm{t}_{\mathrm{fs}} / 2$ & $\mathrm{y}_{4} *\left(\mathrm{E}_{\mathrm{frp}} / \mathrm{E}_{\mathrm{s}}\right) * \mathrm{t}_{\mathrm{fs}} * \mathrm{~b}_{\mathrm{eff}}$ \\
\hline $\begin{array}{c}\text { Total } \\
\text { Equilibrium } \\
\text { Equation }\end{array}$ & $\sum A_{n}$ & & $\sum\left(A_{n} y_{n}\right)$ \\
\hline
\end{tabular}


For each of the bridges in this study, strain gages were applied to the top and bottom flanges of the girders. Strains were recorded for a number of truck positions for each bridge. Negative, or compressive strains were measured at the top flange, while positive, or tensile strains were measured at the bottom flange. Using a linear relationship between the top and bottom flange strains, the neutral axis of each beam section, $\mathrm{Y}$, was determined to be at the position where the strain was zero. This neutral axis position was calculated for each of the interior beams in the bridge cross section and an average was taken.

Once the average neutral axis value was computed, that value was used in the equilibrium equation, shown in Table 1-2, to find the effective width, $b_{\text {eff. }}$ The obtained value of effective width for each of the bridges in this study is discussed in Chapter 3 along with the AASHTOprescribed values for the effective width of a similar depth concrete deck.

\subsubsection{Engaging Effective Deck Width with Shear Connectors}

The effective width of the deck is engaged through a stress transfer across the girder flange-deck interface affected by shear connectors, most typically shear studs (Figure 1-2). Shear connections for concrete decks are designed to have sufficient strength to develop the lesser of the tensile capacity of the supporting girder flange or the compressive capacity of the concrete deck. The AASHTO (2004) equation for determining the nominal capacity of a single shear stud connector embedded in a concrete slab, $\mathrm{Q}_{\mathrm{n}}$, is:

$$
Q_{n}=0.5 A_{s c} \sqrt{f^{\prime}{ }_{c} E_{c}} \leq A_{s c} F_{u}
$$

Where $\mathrm{A}_{\mathrm{sc}}=$ area of shear connector

$$
\begin{aligned}
& f_{c}{ }^{\prime}=\text { specified compressive strength of concrete } \\
& E_{c}=\text { modulus of elasticity of concrete } \\
& F_{u}=\text { specified minimum tensile strength of stud }
\end{aligned}
$$


The first term in Equation 1.1 represents the strength of the confining concrete while the second represents the ultimate capacity of the shear connector. For GFRP decks, Moon et al. (2002) suggested that due to the occurrence of face plate bearing failure before crushing of the confining grout, a new relationship be used for developing the capacity of a shear stud (Moon et al. 2002):

$$
Q_{n}=t_{f s} d_{s C} F_{f r p} \leq A_{s C} F_{u}
$$

Where $\mathrm{t}_{\mathrm{fs}}=$ thickness of the bottom face sheet

$$
\begin{aligned}
\mathrm{d}_{\mathrm{sc}}= & \text { diameter of shear connector } \\
\mathrm{F}_{\mathrm{frp}}= & \text { longitudinally-directed compressive strength of composite material comprising } \\
& \text { bottom face sheet }
\end{aligned}
$$

The first term of Equation 1.2 limits the capacity of the connection to the edge bearing capacity of the bottom face sheet of the GFRP deck. This is a lower bound value as it is unlikely that the shear connector will come to bear directly against the face sheet and it does not take into account the distribution of load resulting from the larger area of the grout pocket.

\subsubsection{Push-off Tests to Determine Stud Capacity}

For projects involving the replacement of a bridge deck, the ability of the new deck to develop composite action is especially important in cases where the existing bridge deck was designed for composite action between the deck and the underlying girders. It is clear that in this case the replacement bridge deck may be required to exhibit composite behavior in order to achieve a similar girder capacity and stiffness. From a load carrying standpoint it may be possible that the reduced dead load due to the replacement of a conventional concrete bridge deck with an GFRP bridge deck may reduce the need to develop composite action, it is doubtful that the stiffness criteria of the bridge will be satisfied without preserving some degree of 
composite action. It is for these reasons that importance is placed on the capacity of the shear connections between the GFRP deck and steel girders. As a way to quantify the interfacial capacity and response of such connections, a conventional concrete-to-steel test, commonly referred to as a "push-off" test, is adapted for the testing of GFRP-to-steel girder connections. For the most part, the push-off test is performed to determine the ultimate capacity and shear-slip behavior of the shear stud used in the connection between the deck and the steel girders.

For the push-off test, a typical specimen is comprised of a few main components. There is a steel beam with shear studs welded to each flange, typically in pairs of 2 or 3 . The GFRP panels in the tests reported in this work came from Martin Marietta with holes already cut for the insertion of the shear studs; this would be the case in the field as well. Formwork supports are used in the attachment of the GFRP panels to the steel girder to support the deck and to provide a grouted haunch. The tubular voids in which the shear studs are located are filled with grout within the limits of foam dams and the entire bottom void is filled with concrete (See Fig. 1-3). The final specimen is then placed in a testing frame and load is applied via a hydraulic actuator (See Fig. 1-4). The results of various push-off tests reported in the literature are tabulated in Table 1-3. 


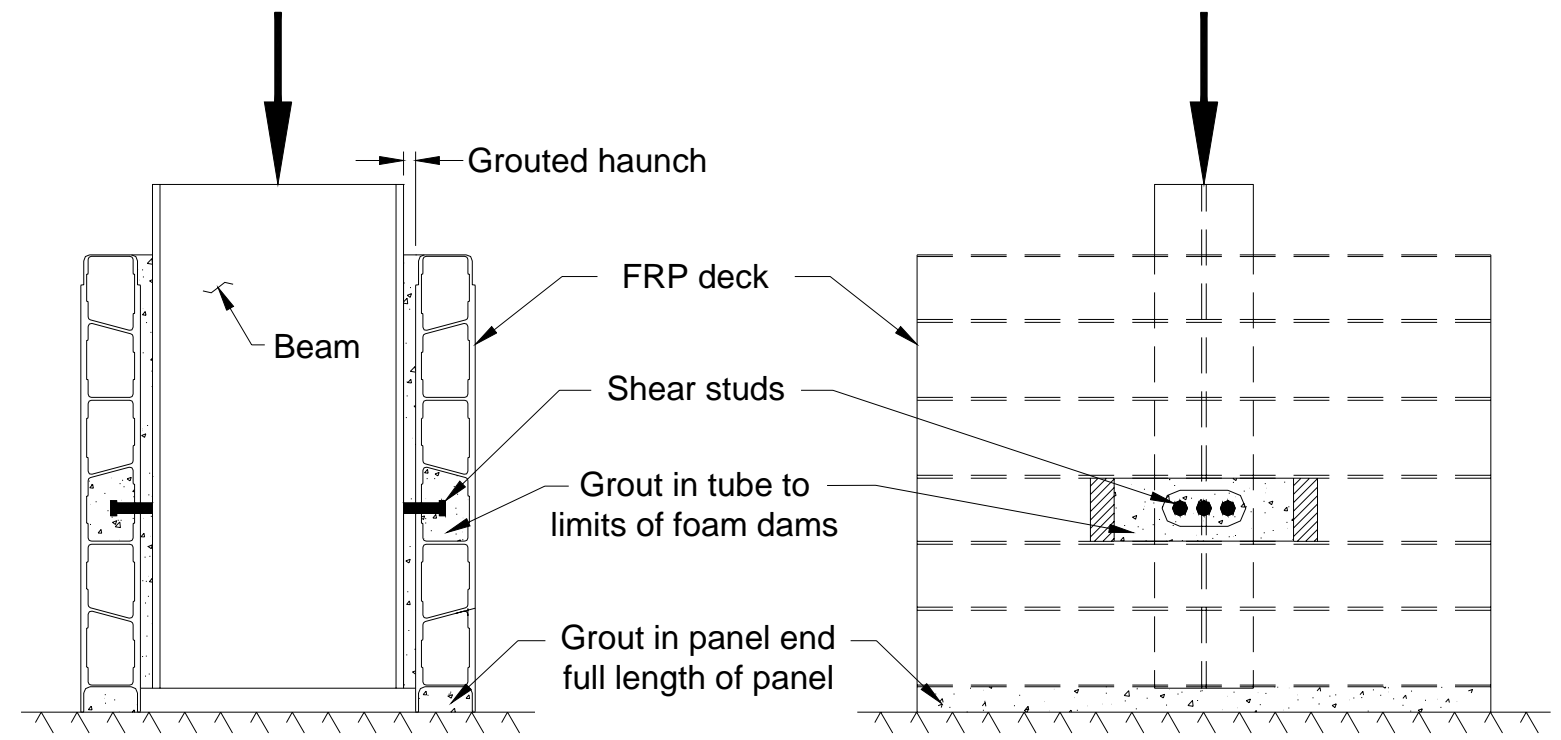

Figure 1-3: Push-off Test Specimen

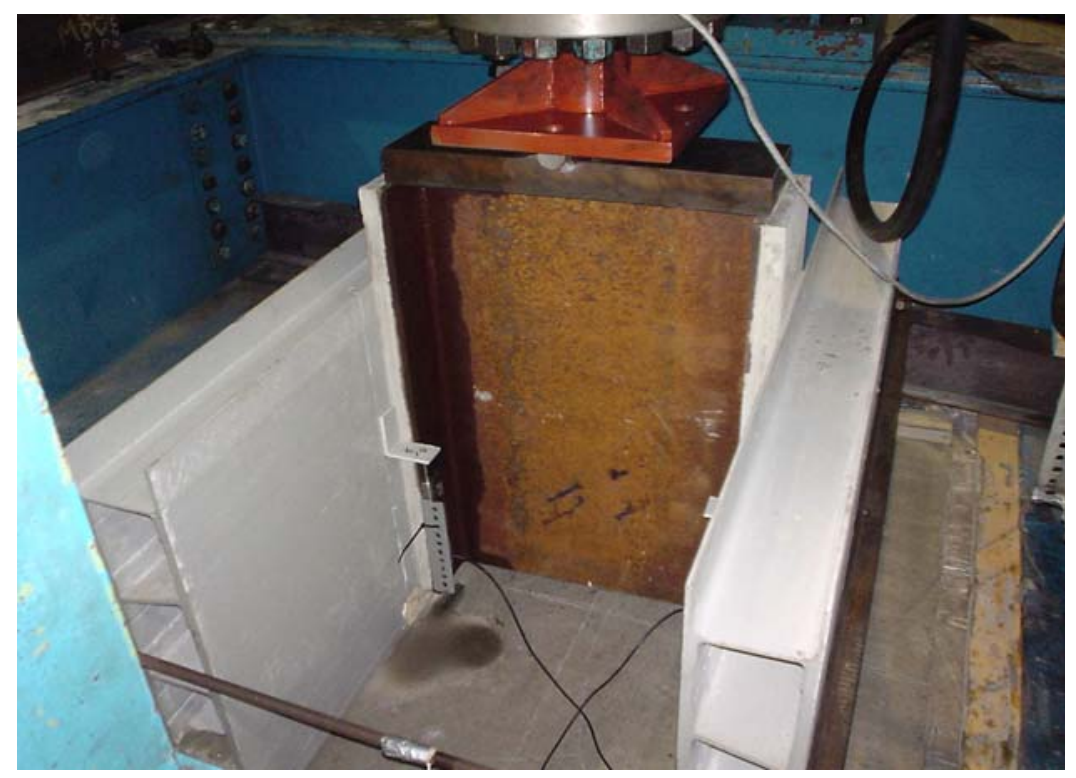

Figure 1-4: Push-off Test Specimen in Load Frame (Yulismana 2005) 
Table 1-3: Shear Stud Capacities for Various Tests

\begin{tabular}{|c|c|c|c|c|c|c|c|c|c|}
\hline Researcher & Sample & Deck Type & $\begin{array}{l}\text { Studs/ } \\
\text { Panel }\end{array}$ & $\begin{array}{c}\text { Stud } \\
\text { Diameter } \\
\text { mm (in) }\end{array}$ & $\begin{array}{c}\text { Observed } \\
\text { Strength/Stud } \\
\text { kN (kips) }\end{array}$ & $\begin{array}{c}\text { Nominal Stud } \\
\text { Capacity from } \\
\text { AASHTO } \\
\text { kN (kips) } \\
\text { (Eq. 1.1) }\end{array}$ & $\begin{array}{c}\text { Nominal Stud } \\
\text { Capacity from } \\
\text { Moon } \\
\text { kN (kips) } \\
\text { (Eq. 1.2) }\end{array}$ & $\begin{array}{c}\text { \% of } \\
\text { AASHTO } \\
\text { Capacity } \\
\text { (Eq. 1.1) }\end{array}$ & $\begin{array}{c}\% \text { of } \\
\text { Moon } \\
\text { Capacity } \\
\text { (Eq. 1.2) }\end{array}$ \\
\hline \multirow{4}{*}{$\begin{array}{l}\text { Yulismana } \\
\text { (2005) }\end{array}$} & 1 & & 2 & $(7 / 8)$ & $\begin{array}{ll}88.7 & (20.0)\end{array}$ & $160 \quad(36)$ & $124 \quad(28)$ & $56 \%$ & $71 \%$ \\
\hline & 2 & 5" MMC & 2 & $(7 / 8)$ & (19.5) & (36) & (28) & $54 \%$ & $70 \%$ \\
\hline & 3 & Duraspan & 2 & $(7 / 8)$ & (21.0) & (36) & (28) & $58 \%$ & $75 \%$ \\
\hline & 4 & & 2 & $(7 / 8)$ & $(18.6)$ & (36) & (28) & $52 \%$ & $66 \%$ \\
\hline \multirow{2}{*}{$\begin{array}{l}\text { Turner et } \\
\text { al. (2003) }\end{array}$} & 1 & 7.66" MMC & 3 & $(7 / 8)$ & $(25.0)$ & (36) & $152 \quad(34)$ & $69 \%$ & $74 \%$ \\
\hline & 2 & Duraspan & 3 & $(7 / 8)$ & (32.7) & (36) & $152 \quad(34)$ & $91 \%$ & $96 \%$ \\
\hline \multirow{3}{*}{$\begin{array}{l}\text { Moon et al. } \\
\text { (2002) }\end{array}$} & 1 & $\begin{array}{c}7.66 " \text { MMC } \\
\text { (Gen 3) }\end{array}$ & 3 & $(7 / 8)$ & $126.1 \quad(28.4)$ & (36) & $75 \quad(17)$ & $79 \%$ & $167 \%$ \\
\hline & 2 & 7.66" MMC & 3 & $(7 / 8)$ & $104.0 \quad(23.4)$ & (36) & $(12)$ & $65 \%$ & $195 \%$ \\
\hline & 3 & (Gen 4) & 3 & $(7 / 8)$ & $116.0 \quad(26.1)$ & (36) & $55 \quad(12)$ & $73 \%$ & $218 \%$ \\
\hline $\begin{array}{c}\text { Drexler } \\
\text { (2005) }\end{array}$ & 1 & $\begin{array}{l}\text { 5" MMC } \\
\text { Duraspan }\end{array}$ & 4 & $(7 / 8)$ & $161.3 \quad$ (36.3) & (36) & $124 \quad(28)$ & $101 \%$ & $130 \%$ \\
\hline
\end{tabular}

Both Moon et al. (2002) and Turner et al. (2003) report the average capacity of shear studs embedded in a GFRP deck grout pocket to be approximately $70-80 \%$ of the capacity of a comparable shear connection in a continuous concrete deck. Similar tests conducted by Yulismana (2005) showed that the shear studs were only able to achieve 52-58 \% of their nominal capacity and only 67-75\% of the capacity suggested by Moon et al. (Equation 1.2). Only the tests conducted by Drexler (2005) report the studs actually reaching the nominal stud capacity given by AASHTO.

However, the test conducted by Drexler utilized two sets of shear stud connections on each side of the test specimen. It is believed that this non-traditional test arrangement can result in greater observed capacities. It is further noted that although the decks have the same geometry, the tests reported by Yulismana and Drexler were conducted on $127 \mathrm{~mm}$ (5”) decks while those of Turner et al. and Moon et al. used the $195 \mathrm{~mm}$ (7.66”) deck considered in the present work. 
The observed decreased capacity was due to failure modes associated with delamination of the GFRP decks. In a GFRP deck, two- or three-stud groups are spaced $610 \mathrm{~mm}$ (24 in.) along the beam and each grouted pocket is only $170 \mathrm{~mm}$ (6.7 in.) long (see Figure 2.1) and may extend $450 \mathrm{~mm}$ (18 in.) perpendicular to the longitudinal girder flange. As a result of these more

discrete connections (as compared to a concrete deck), there is considerable transverse shear lag in a GFRP-to-steel flange connection. Additionally, the in-plane shear stiffness of the deck provided by the webs and grout pockets is inadequate to fully develop the top GFRP face-plate, resulting in a vertical shear lag effect in addition to that in the transverse direction as discussed in the following section. Thus, full composite action, comparable to that obtained in concrete decks cannot likely be achieved at the ultimate load state. Nonetheless, at service load levels considerable composite action can be achieved (Keelor et al. 2004).

\subsubsection{Engaging Effective Deck Width with Adhesively Bonded Deck Systems}

As discussed, some of the difference between the behavior of GFRP and concrete decks may stem from the discrete nature of the shear stud connections provided. A recent study by Keller et al. (2004) investigated the possibility of improving the shear transfer between GFRP deck and steel girder by adhesively bonding the deck to the girder, thus providing a continuous shear transfer between steel girder and GFRP deck. In this study, composite behavior is reported at service and ultimate load levels. The degree of composite behavior achieved was affected by the in-plane longitudinal shear stiffness of the GFRP deck. While there was no strain discontinuity reported at the girder-GFRP deck interface, there was significant shear lag between the top and bottom face plates of the GFRP deck resulting in top plate strains of only approximately $55 \%$ of those observed in the bottom face plate (for the same deck type reported 
in the present work). Since the deck was adhesively connected to the girders, no grout pockets were provided, likely reducing the efficiency of the through-deck shear transfer to some degree.

Although preliminary, the results of this study clearly indicate the importance of the inplane shear behavior in determining the expected degree of composite action. Keller et al. (2004) report results using two different GFRP deck systems designed to carry comparable loading. Nonetheless, the deck cell geometry differed such that the in-plane shear stiffness of the decks differed by a factor of eight. The deck having lower in-plane shear stiffness (the same deck type discussed in the present work) exhibited a composite stiffness at service load level of only $74 \%$ of that of the stiffer deck. Additionally, the ultimate failure mode of the two deck types differed: the deck having lower in-plane shear stiffness failed in the bottom face plate while the stiffer deck exhibited a failure that engaged the entire deck depth.

\subsubsection{Moment Distribution Factors}

Moment distribution factors (DF) are design tools used to determine the maximum expected moment each supporting girder must be able to resist given the strength contributions of adjacent superstructure elements. Alternatively, they may be seen as factors describing the manner in which the design live loads will be distributed to the supporting girders making up the superstructure. These factors are given as a fraction of the design live load. Dead loads are assumed to be distributed to superstructure elements in a uniform manner (AASHTO 2004).

An accurate assessment of moment distribution factors is critical for new bridge design. The use of GFRP decks requires an evaluation of distribution factors for these decks so that girder design forces are appropriately evaluated. For bridge deck replacement applications, the behavior of the replacement deck should approximate that of the original deck with regard to distribution. If, for instance, the distribution is more critical (less transverse distribution of wheel 
loads) for the replacement GFRP deck, girders adjacent to wheel loads will see proportionately greater stress due to a given live load. It is important to note that the reduced dead load of the GFRP deck may have the effect of reducing overall girder stresses, but does not affect the live load-induced stress range, which may be critical for fatigue considerations. Thus, distribution factors for GFRP replacement decks that differ significantly from those of the original concrete decks may aggravate fatigue-sensitive details. This is discussed further by way of an example presented in Chapter 4.

There are a number of acceptable methods to calculate the moment distribution factor. This study reports the distribution factors found from the field data and compares these to the distribution factors arrived at by using these various AASHTO-prescribed methods. As a basis for comparison, the distribution factor for interior girders, assuming a concrete deck on steel girders, for two design lanes loaded, is calculated as (AASHTO (2004) Clause 4.6.2.2.2):

$$
D F=0.075+\left(\frac{S}{2900}\right)^{0.6} \times\left(\frac{S}{L}\right)^{0.2} \times\left(\frac{K_{g}}{L \cdot t_{S}^{3}}\right)^{0.1}
$$

Where $\mathrm{S}$ = the center to center spacing of the longitudinal girders, mm;

$\mathrm{L}=$ the total span length of girder, $\mathrm{mm}$;

$\mathrm{K}_{\mathrm{g}}=$ longitudinal stiffness parameter (AASHTO (2004) Eq 4.6.2.2.1-1); and

$t_{\mathrm{s}}=$ depth of slab (substituted with depth of GFRP deck), mm.

Since the AASHTO Standard Specifications (AASHTO 1996) are still commonplace in design practice, the AASHTO 1996 distribution factors are also considered. For interior girders, the distribution factor, assuming a concrete deck on steel girders, for two design lanes loaded, is calculated as (AASHTO (1996) Clause 3.23.2):

$$
D F=0.5\left(\frac{S}{1700}\right)
$$


Where $\mathrm{S}=$ the center to center spacing of the longitudinal stringers, $\mathrm{mm}$.

The 0.5 factor in Equation 1.4 accounts for normalization of the AASHTO 1996 wheelpath load (both front and rear) to that of LRFD full truck load used for design.

Finally, the "lever rule" (AASHTO 2004) - a simple static distribution of forces transversely across the bridge assuming the deck is hinged at each girder - yields an alternate conservative approach to estimating the distribution factor. In the case of the lever rule, wheel loads are only carried by the two girders immediately adjacent the wheel location.

\subsubsection{Calculating Moment Distribution Factors from In-situ Tests}

Actual moment distributions observed during load tests may be calculated from consistently-located observed girder strains at a particular section of the bridge:

$$
D F_{\text {girder }_{j}}=\frac{\operatorname{strain}_{j}}{\sum_{\text {all_girders }} \text { strain }}
$$

As described in Chapter 3, moment distribution factors were derived from girder strain data and calculated using Equation 1.5. Distribution factors calculated from test results are affected by the geometry of the load vehicle and load path used. In certain cases where there are discrepancies from AASHTO-prescribed geometry, it is believed that the calculated values of moment distribution factors are affected. If the gage distance, or axle width, of the test vehicle is a value other than the $1830 \mathrm{~mm}$ (72 in.) prescribed by AASHTO, the observed distribution factors would have some degree of inaccuracy. Zokaie et al. (1992) report that experimentally observed distribution factors will be lower when the test vehicle gage distance is larger than that used to calibrate the AASHTO guidelines. Similarly, small gage distances may result in higher distribution factors. 
The distribution factor calculation is also affected by the passing distance between the trucks. The passing distance is the distance between the wheel paths of multiple trucks. The AASHTO prescribed passing distance is $1220 \mathrm{~mm}$ (4 ft.). An increase in passing distance will result in lower calculated distribution factors. The concept of the governing load case in calculating distribution factors, that is, two or more design lanes, is to have as many truck wheel paths as close to a single girder as possible within the guidelines of AASHTO.

\subsection{SCOPE OF THESIS}

The objective of this work is to evaluate effective width and distribution factors for the most commonly used GFRP deck system, the $195 \mathrm{~mm}$ (7.66”) Martin Marietta Composites (MMC) DuraSpan product. The parameters are established using data from multiple load tests on three existing steel multi-girder bridges described in Chapter 2. In Chapter 3, the resulting experimentally determined effective widths and distribution factors are compared to comparable values used for the design of concrete decks. Finally, an example, based on one of the described bridges, assessing girder stresses both before and after concrete deck replacement is presented in Chapter 4. 


\subsection{DESCRIPTIONS OF BRIDGES REPORTED IN THIS STUDY}

The commercially available (MMC 2001) 195 mm (7.66 in.) deep GFRP bridge deck panels considered in this study are formed by assembling $305 \mathrm{~mm}$ (12 in.) long interlocking pultruded elements. (For consistency throughout this thesis, directions are given in terms of the bridge orientation; thus "longitudinal" refers to the direction of traffic flow and the GFRP deck system primary (one-way) flexural behavior is in the "transverse" direction.) The trapezoidal tube deck design was designed to optimize stiffness of the system as well as to reduce material usage (Motley et al. 2002). Fibers are placed so as to create a well balanced composite system designed to behave in an isotropic manner (once assembled) at the plate component level, thus providing strength and stiffness in all directions. The interlocking elements may be joined together to form any length of deck necessary. Figure 2-1 shows a $610 \mathrm{~mm}$ (24 in.) long section of this deck system made up of two interlocking elements. Full bridge-width preassembled panels (typically $3.05 \mathrm{~m}$ (10 ft) in length) are delivered to the bridge site. Final placement, interlocking, and bonding of the panels occurs on site. The GFRP panels are expected to act compositely with the supporting steel girders. To develop composite action, two or three $22 \mathrm{~mm}$ (7/8 in.) diameter, $150 \mathrm{~mm}$ (6 in.) tall shear studs are located in grouted pockets spaced at 610

$\mathrm{mm}(2 \mathrm{ft})$ along the entire length of each girder. Descriptions of each of the bridges considered in this study are provided in the following sections. 


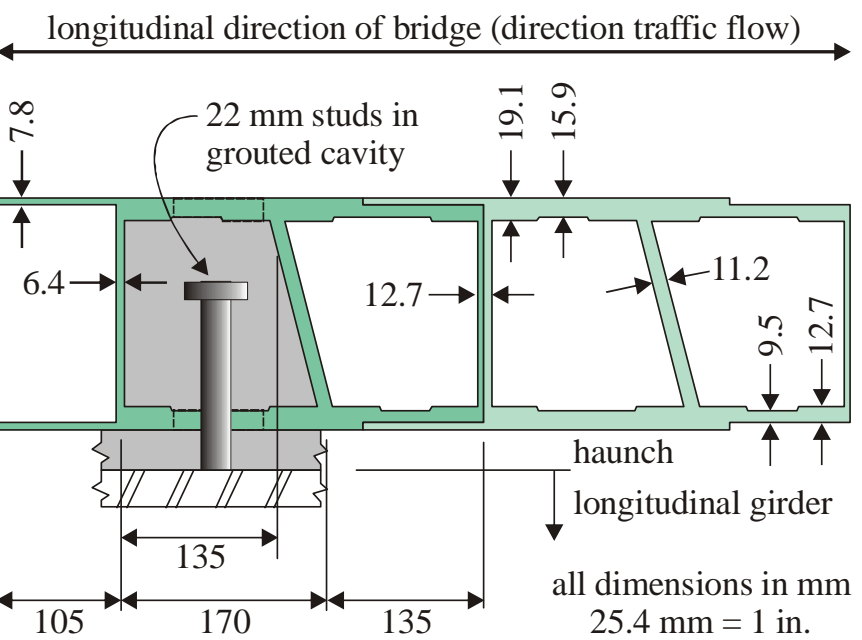

Figure 2-1: Transverse Section GFRP Deck Geometry and Dimensions. The GFRP deck depth is 195 mm (Turner 2003).

Many of the demonstration bridges reported in the literature have been subject to limited proof load testing of some kind. A number of the existing GFRP bridges have been instrumented to varying degrees and subject to in situ load testing and long term health monitoring programs. The objective of the present study is to evaluate distribution factor and deck effective width recommendations as they apply to GFRP decks at service load conditions. To this end, a limited scope of bridge parameters was considered. Three bridges were selected as described below. Each has a straight alignment and has the same GFRP deck type (MMC 2001) on steel girders. Each bridge was sufficiently instrumented and subject to loading such that response parameters of interest may be calculated. A summary of the bridge characteristics and load test configurations is provided in Table 2-1. 
Table 2-1: Summary of Bridge Details

\begin{tabular}{|c|c|c|c|c|}
\hline Bridge & $\begin{array}{c}\text { Instrumented } \\
\text { span length } \\
\end{array}$ & $\begin{array}{c}\text { Girders }^{1} \text { and } \\
\text { spacing }\end{array}$ & Test load $^{2}$ & Time of $\operatorname{test}(s)^{3}$ \\
\hline $\begin{array}{l}\text { Fairground Road Bridge } \\
\text { (BDI 2003) }\end{array}$ & $20.7 \mathrm{~m}(68 \mathrm{ft})$ & $\begin{array}{c}4-\text { W36x260@ } \\
2847 \text { mm (9.33 ft) }\end{array}$ & $\begin{array}{l}\text { test } 1: \text { H34.5 } \\
\text { test } 2: \text { H29.5 }\end{array}$ & $\begin{array}{l}\text { test 1: } 180 \text { days } \\
\text { test 2: } 925 \text { days }\end{array}$ \\
\hline $\begin{array}{l}\text { Boyer Bridge } \\
\text { (Luo 2003) }\end{array}$ & $\begin{array}{l}12.7 \mathrm{~m} \\
(41.5 \mathrm{ft})\end{array}$ & $\begin{array}{l}\text { 5-W24x104@ } \\
1754 \text { mm (5.75 ft) }\end{array}$ & $\begin{array}{l}\text { test } 1: \text { H28.2 } \\
\text { test } 2: \text { H32.6 } \\
\text { test } 3: \text { H26.6 } \\
\text { test } 4: \text { H22.8 }\end{array}$ & $\begin{array}{l}\text { test } 1: 31 \text { days } \\
\text { test } 2: 125 \text { days } \\
\text { test } 3: 159 \text { days } \\
\text { test } 4: 950 \text { days }\end{array}$ \\
\hline $\begin{array}{c}\text { SC S655 } \\
\text { (Turner et al. 2004) }\end{array}$ & $\begin{array}{c}17.5 \mathrm{~m} \\
(57.5 \mathrm{ft})\end{array}$ & $\begin{array}{l}\text { 5-W36x150@ } \\
2440 \text { mm (8.00ft) }\end{array}$ & $\begin{array}{l}\text { test } 1: 2-\mathrm{H} 23.7 \\
\text { test } 2: 2-\mathrm{H} 24.3 \\
\text { test } 3: 2-\mathrm{H} 23.7\end{array}$ & $\begin{array}{l}\text { test } 1: 228 \text { days } \\
\text { test } 2: 445 \text { days } \\
\text { test } 3: 614 \text { days }\end{array}$ \\
\hline
\end{tabular}

${ }^{1}$ girders given in U.S. designation (inches $\mathrm{x}$ pounds/foot)

2 AAHSTO 2004 designation

${ }^{3}$ approximate age of bridge measured from time of bridge opening to traffic.

\subsection{TYPICAL GFRP DECK PANEL INSTALLATION}

Figure 2-2 shows a few key steps in the installation of a typical GFRP deck panel (the Boyer Bridge deck installation is shown). Full bridge-width preassembled panels are delivered to the site (Fig. 2-2a). The panels are then placed by a crane onto the superstructure (Fig. 2-2b). The panel is jacked into place using a mechanical jack and adhesive is placed on the interlocking surface of the panel (Fig. 2-2c). Once the panels are in place, they are attached to the girders by the use of shear studs embedded in a grout pocket that fills a portion of one of the tubular voids of the GFRP deck (See Figure 2-1).

Shear studs are attached to the beam in groups of 2 or 3 in the grout pockets of the deck located longitudinally along the bridge. The shear studs are attached to the girder after deck panel placement using a stud gun (Fig. 2-2d). The pocket in which the studs are located is filled with grout once all the studs are placed. Figure 2-2e shows all the deck panels in place and all of the stud pockets filled with grout. In many cases, such as the installation of the Boyer Bridge (the example shown in Figure 2-2), the deck placement can be completed in one working day. Once 
the deck is placed, an asphalt or epoxy-modified concrete wearing surface is applied to the deck (Fig. 2-2f). The speed with which a GFRP deck can be placed is one of the benefits to using a GFRP deck system. The three GFRP bridge deck structures considered in this work are presented in the following sections. 


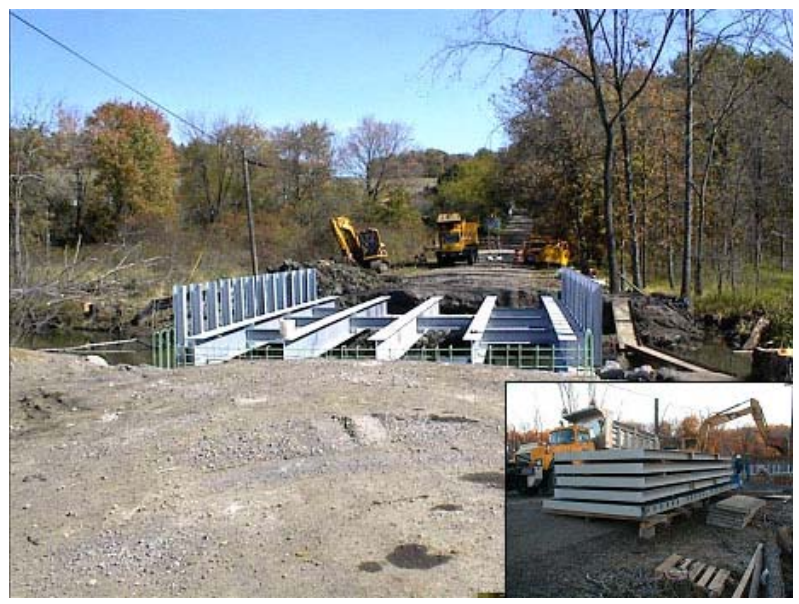

(a)

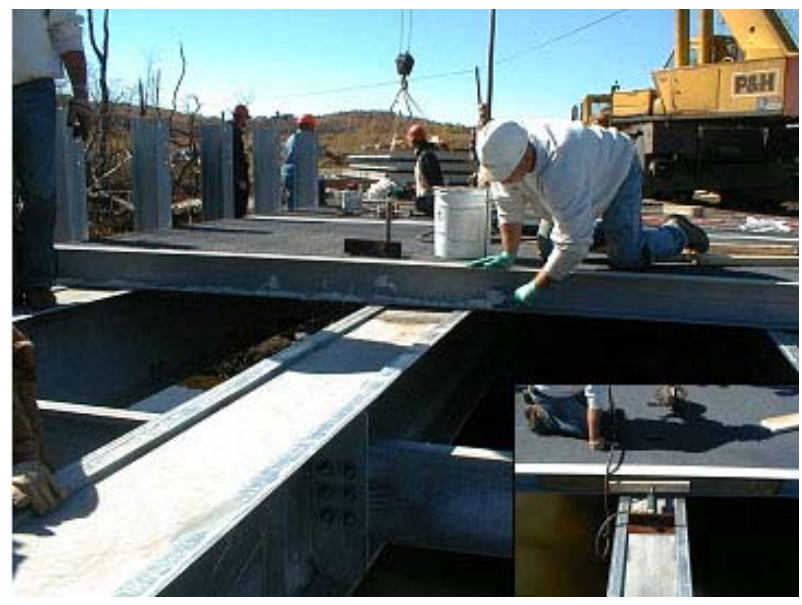

(c)

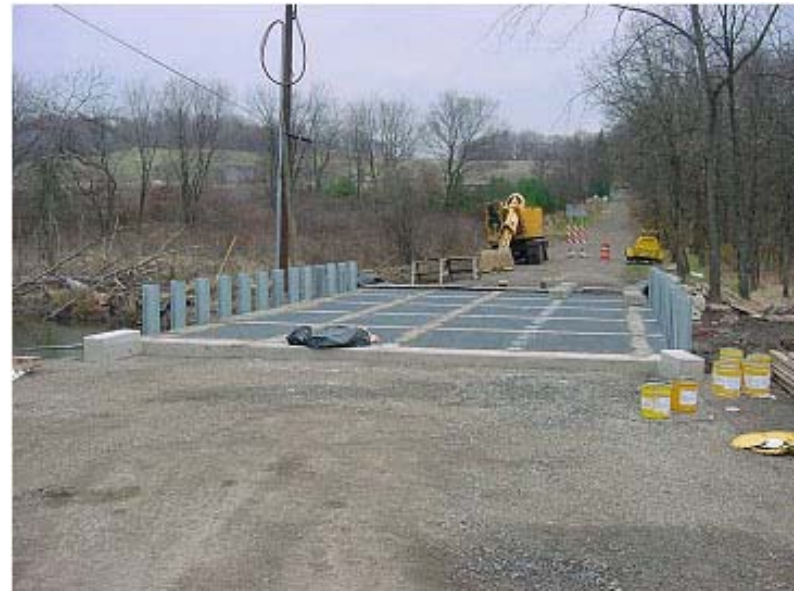

(e)

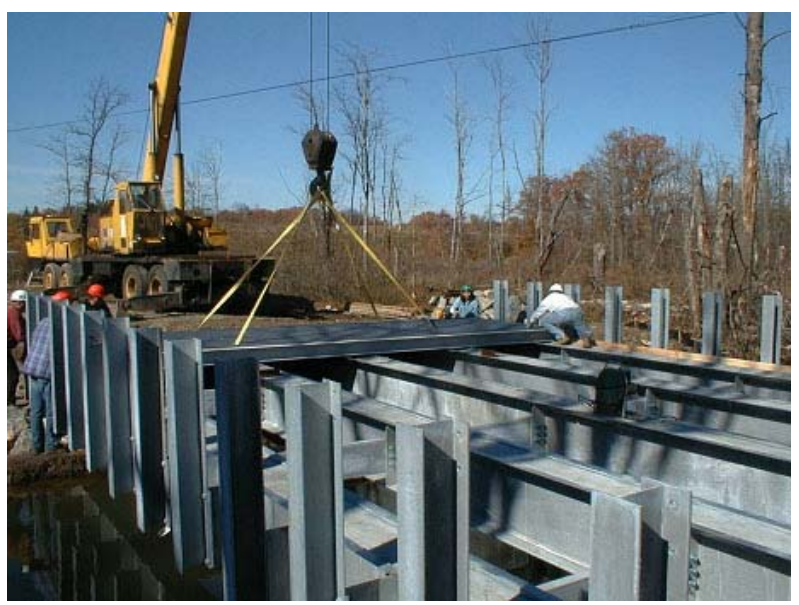

(b)

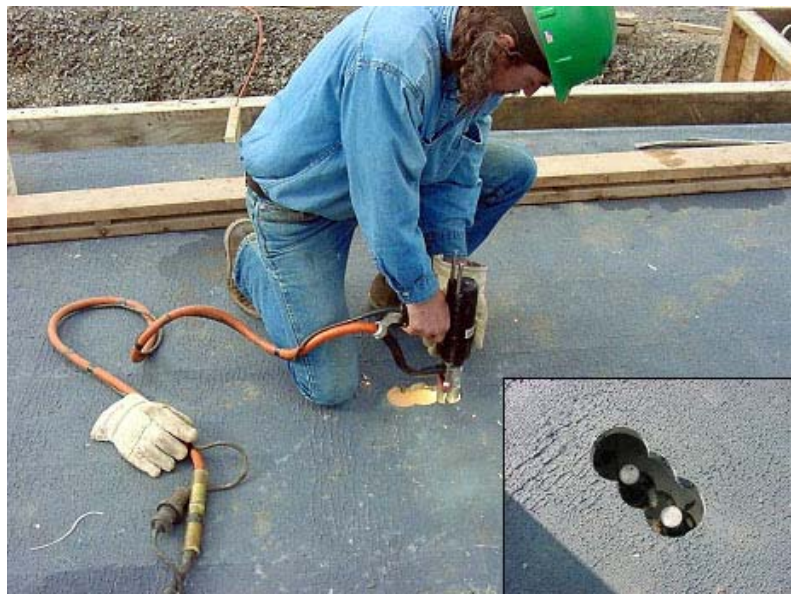

(d)

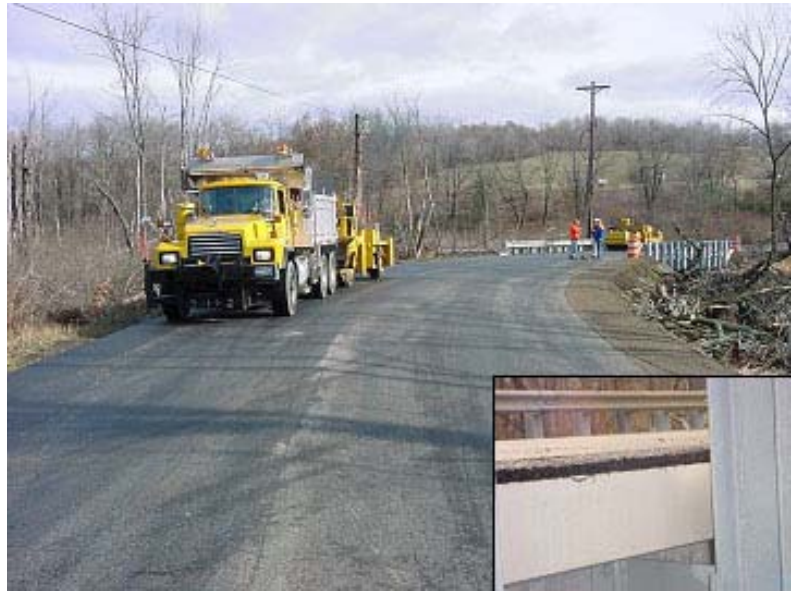

(f)

Figure 2-2: Installation of GFRP deck panels (Boyer Bridge) 


\subsection{FAIRGROUND ROAD BRIDGE}

The Fairground Road Bridge in Greene County Ohio (BDI 2003) is a 3-span continuous steel bridge. It has span lengths of 20.7, 25.9 and $20.7 \mathrm{~m}$ (68, 85 and $68 \mathrm{ft}$ ) each consisting of four W36x260 (U.S. designation) beams having a transverse spacing of $2847 \mathrm{~mm}$ (9.33 ft) (see Figure 2-3). The $195 \mathrm{~mm}$ (7.66 in.) deep GFRP deck (MMC 2001) is attached to the girders with three $22 \mathrm{~mm}$ (7/8 in.) diameter, $150 \mathrm{~mm}$ (6 in.) long shear studs located in grouted pockets spaced at $610 \mathrm{~mm}$ (24 in.) along the girders. This connection is intended to allow the deck to act compositely with the girders. All four beams of the first $20.7 \mathrm{~m}$ span were instrumented with electrical resistance strain gages as shown in Figure 2-3(b). The gages were located near midspan, 10,023 mm (32.9 ft) from the centerline of the abutment (although additional instrumentation was provided, only that discussed in this thesis is presented here). Load tests were conducted in October 2002 and 2004 using single dump trucks weighing 307 kN (69 kip) and $262 \mathrm{kN}$ (59 kip), respectively. These loading vehicles are approximately equivalent to AASHTO (2004) H34.5 and H29.5 vehicles, respectively. For each test, the truck was driven across the bridge at a "crawling speed" along multiple load paths. Strain data was recorded at $1525 \mathrm{~mm}$ (5 ft) intervals of the truck location. Only the load paths discussed in this work are shown in Figure 2-3 (BDI 2003). These differed somewhat from test 1 to test 2 as indicated in Figure 2-3. Data from the single truck traverses along each load path are superimposed to obtain the data reported for the two-truck load case shown in Figure 2-3 and reported in Chapter 3. 


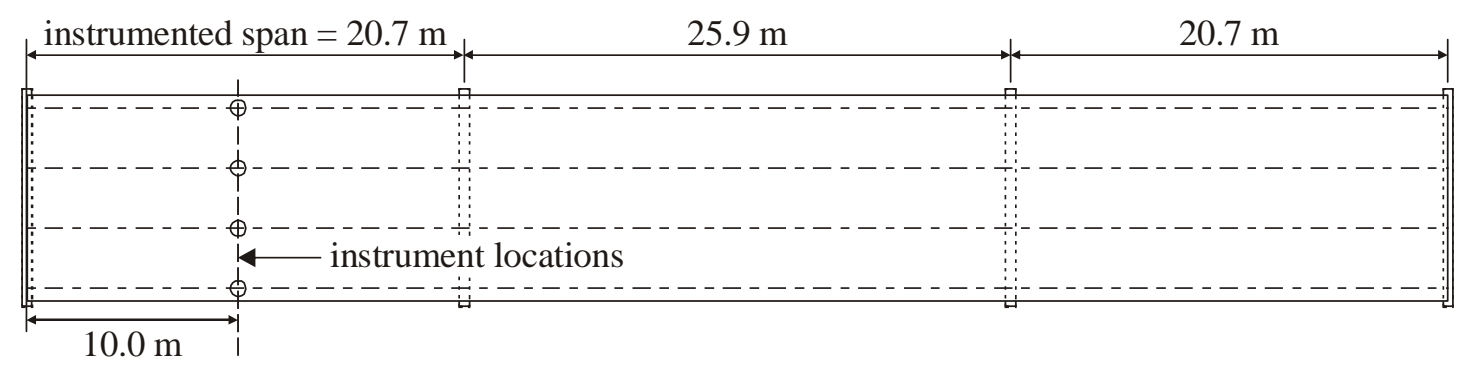

(a) plan view

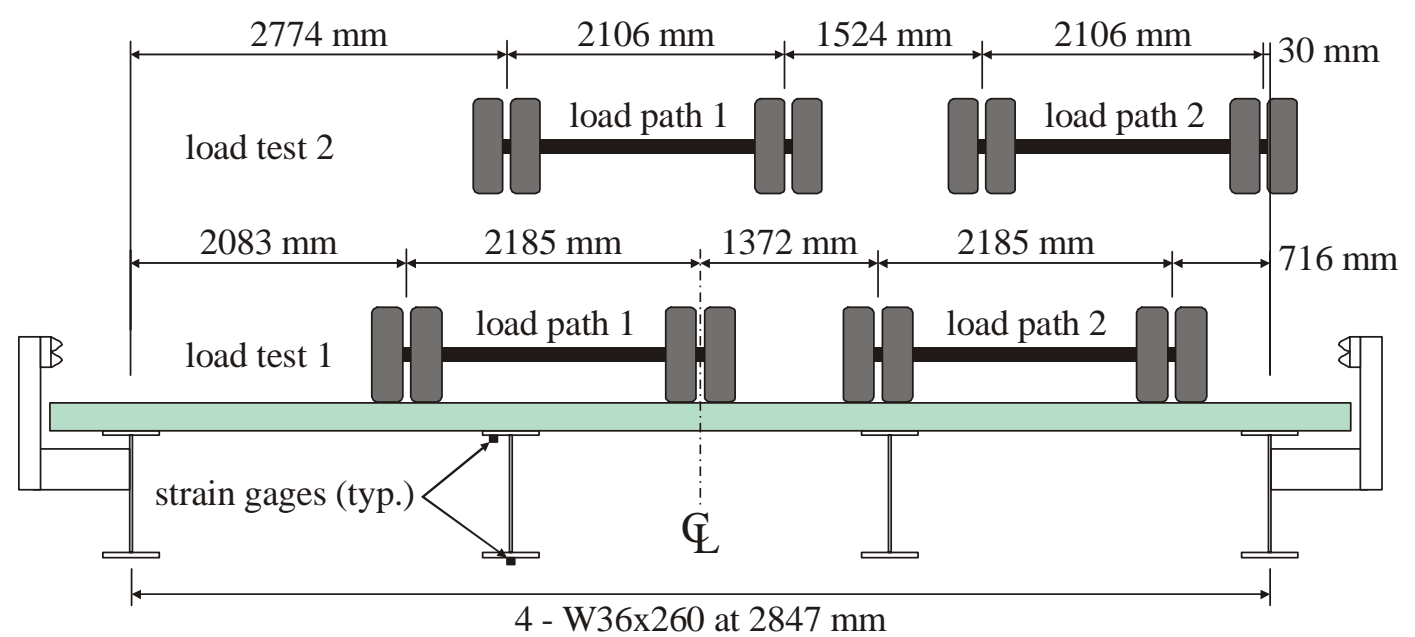

(b) section at instrumentation

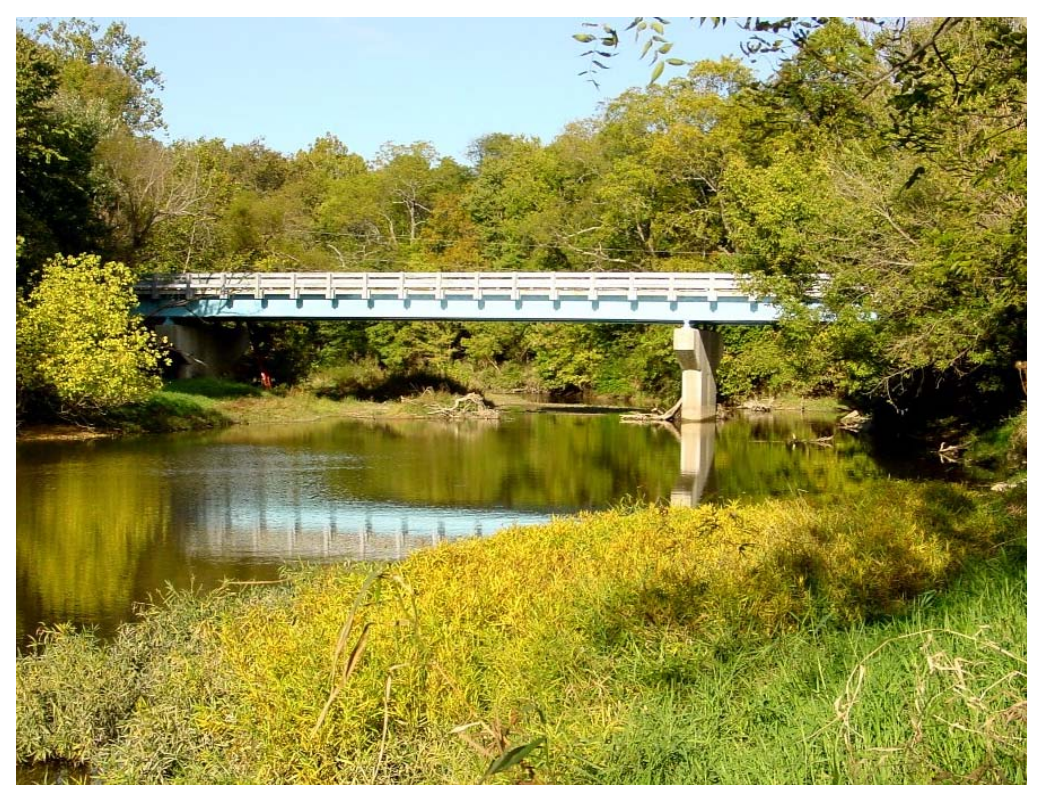

(c) photograph of Fairground Road Bridge

Figure 2-3: Fairground Road Bridge 


\subsection{BOYER BRIDGE}

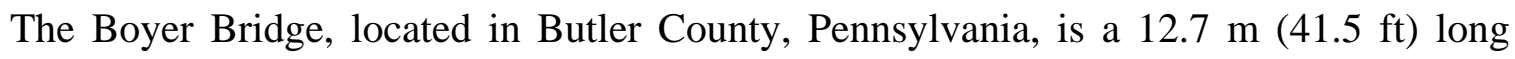
simple span steel multi-girder bridge (Luo 2003). The span consists of five galvanized W24x104 (U.S. designation) girders having a transverse spacing of $1754 \mathrm{~mm}(5.75 \mathrm{ft})$ as shown in Figure

2-4. The $195 \mathrm{~mm}$ (7.66 in.) deep GFRP deck (MMC 2001) is attached to the girders with two 22 mm (0.75 in.) diameter, $150 \mathrm{~mm}$ (6 in.) long shear studs located in grouted pockets spaced at 610 mm (24 in.) along the girders. Electrical resistance strain gages were located on all beams at the bridge midspan as indicated in Figure 2-4(b). Four load tests were conducted using single vehicles having weights indicated in Table 2-1. The load case reported here represents a subset of all load paths tested (Luo 2003); in this case, data for the vehicle traversing two load paths, straddling the second and fourth interior girders, respectively (see Figure 2-4) was superimposed. The vehicles were stopped at three longitudinal locations along the bridge and instrument data was collected. Load tests were conducted three times between November 2001 and March 2002. A fourth test was conducted in May 2004. Only data from exterior girders is available for this last test. 


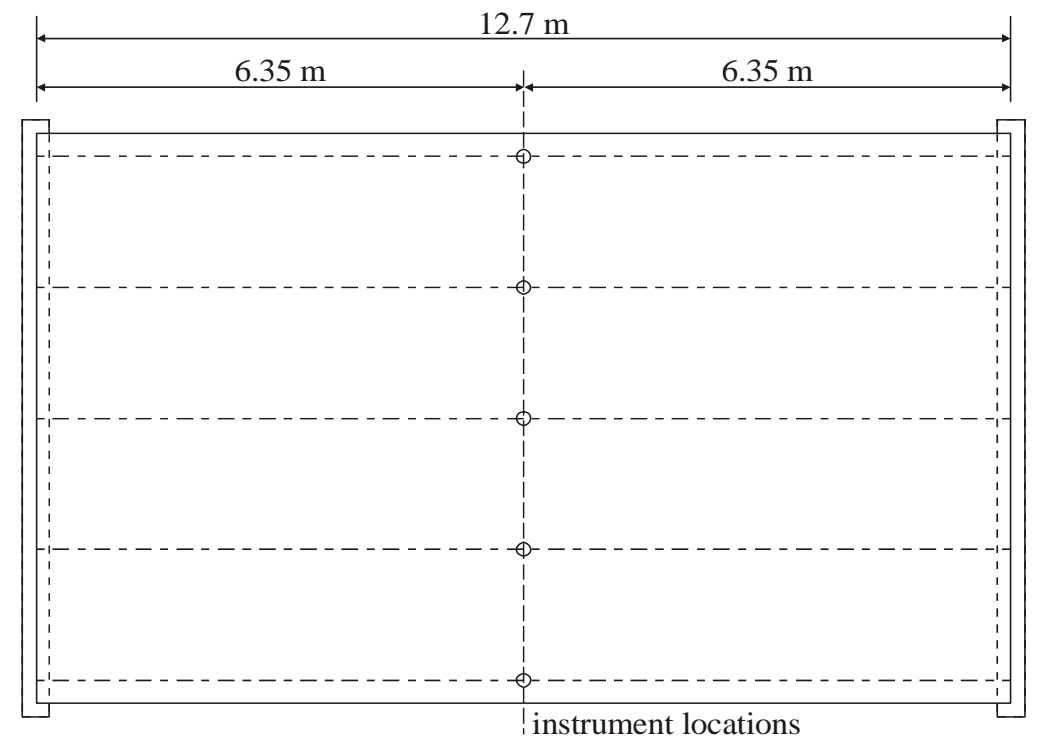

(a) plan view

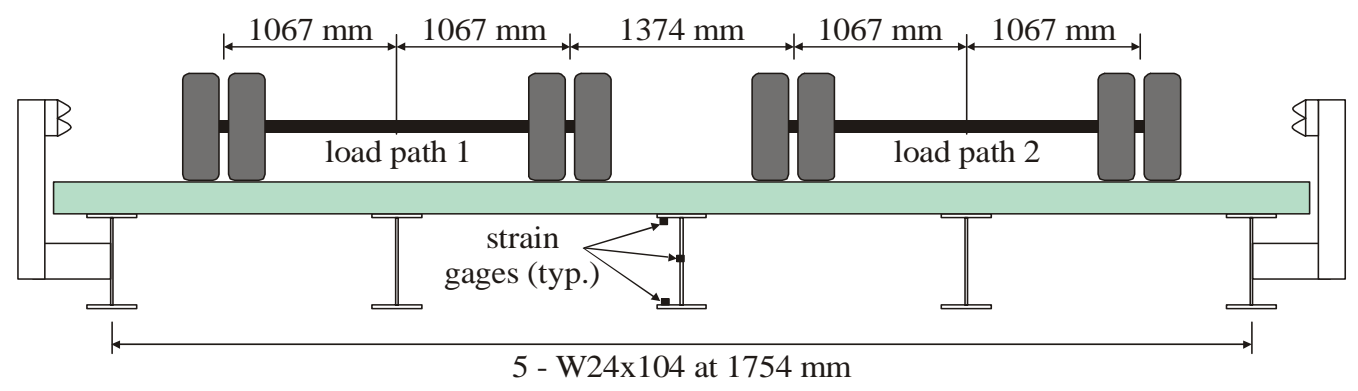

(b) section at instrumentation

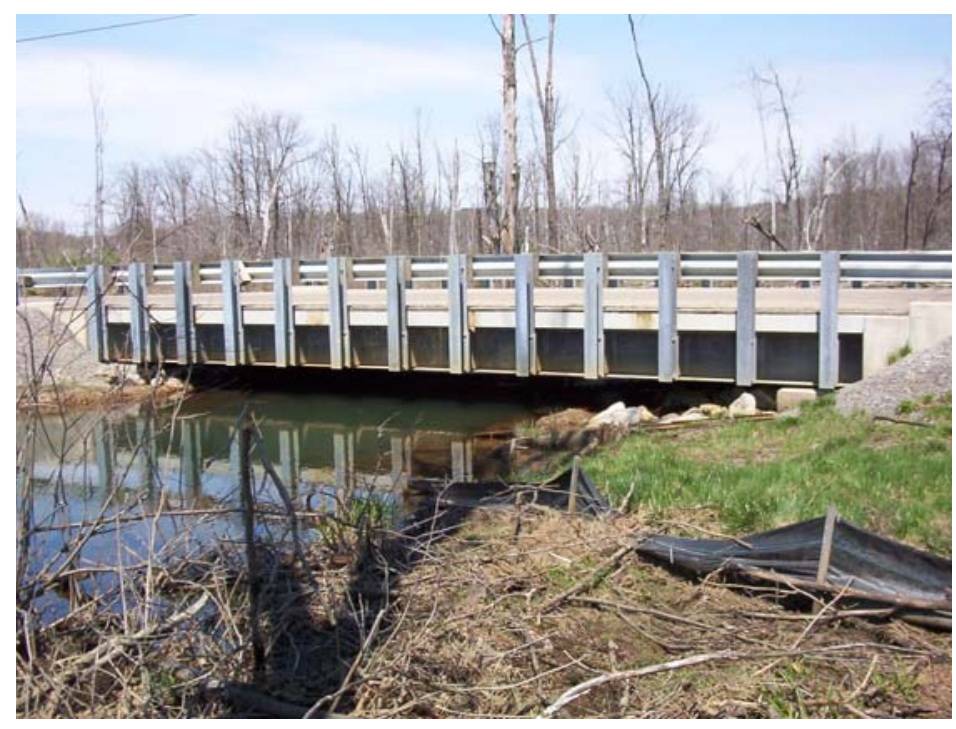

(c) photograph of Boyer Bridge

Figure 2-4: Boyer Bridge 


\subsection{SOUTH CAROLINA S655 BRIDGE}

The bridge located on South Carolina State Road S655 carries S655 over a Norfolk/Southern rail line near Landrum, SC, in Spartanburg County (Turner 2003; Turner et al. 2004). This bridge is a $17.5 \mathrm{~m}(57.5 \mathrm{ft})$ long, single span consisting of five W36x150 (U.S. designation) girders having a transverse spacing of $2440 \mathrm{~mm}(8 \mathrm{ft})$ as shown in Figure 2-5. The $195 \mathrm{~mm}$ (7.66 in.) deep GFRP deck (MMC 2001) is attached to the girders with three $22 \mathrm{~mm}$ (7/8 in.) diameter, $150 \mathrm{~mm}$ (6 in.) long shear studs located in grouted pockets spaced at $610 \mathrm{~mm}$ (24 in.) along the girders. Despite the shear studs, the girders were designed to carry an AASHTO H25 vehicle (AASHTO 2004) on a non-composite concrete deck; thus the girders are significantly over designed for the in situ conditions.

One quarter of the S655 structure was heavily instrumented with electrical resistance strain gages and displacement transducers on both the steel girders and GFRP deck. Instruments were placed at eighth points along the span to midspan (see Figure 2-5). Additionally, global bridge displacements were determined using high-precision surveying techniques (Turner et al. 2004). Multiple symmetric and anti-symmetric load paths were used to extrapolate the complete response of the symmetric structure based on the instrumented quarter structure. The critical load condition (discussed in this study) consisted of two vehicles (equivalent AASHTO loading is given in Table 2-1 for each test) traveling side by side at a wheel path spacing of $1220 \mathrm{~mm}(4 \mathrm{ft})$ as shown in Figure 2-5(b). This load geometry is equivalent to the two-lane design geometry prescribed by AASHTO (2004). The vehicles were stopped at eighth points along the span and data was recorded. Load tests were conducted in July 2002, February 2003, and July 2003. Data from these three bridges and nine load tests are presented in the following chapter. 


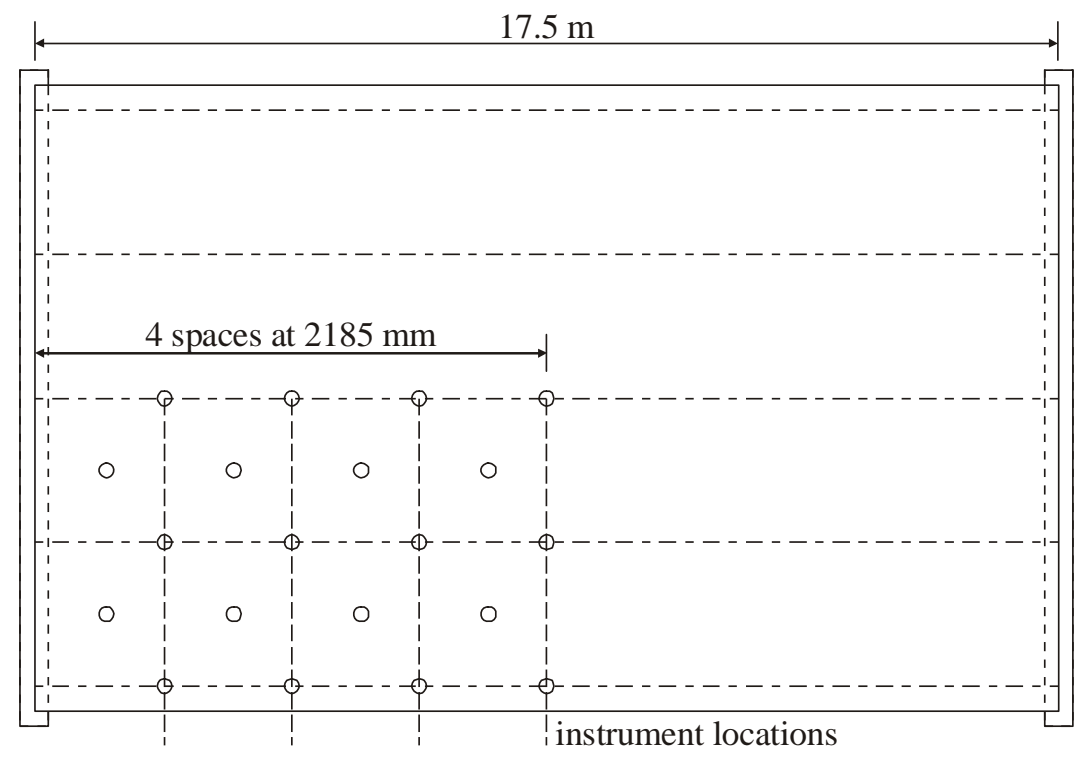

(a) plan view

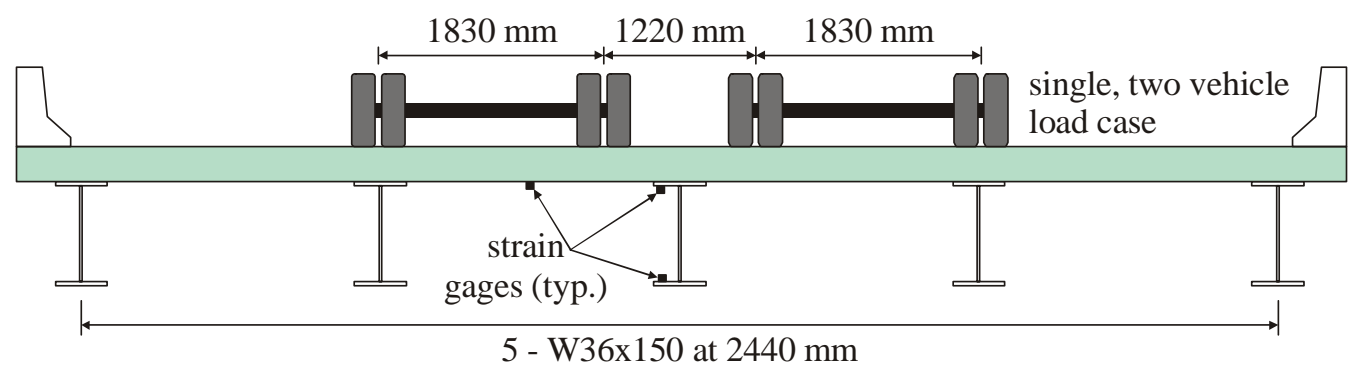

(b) section at instrumentation

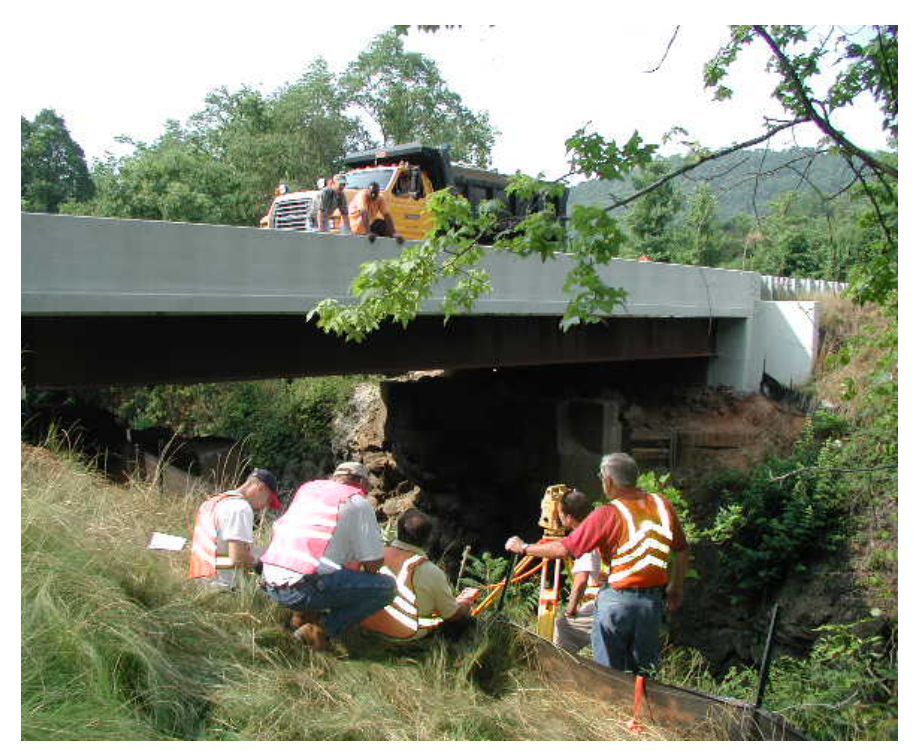

(c) photograph of South Carolina SC655 Bridge

Figure 2-5: South Carolina SC655 Bridge 


\subsection{OBSERVED RESULTS OF LOAD TESTS}

Complete results from all load tests are reported in their respective source references (BDI 2003; Luo 2003; Turner 2003). The present study reports derived behavior parameters for only the critical elements and critical load tests (see Chapter 2) conducted on each structure. It is the objective of the following sections to place these parameters - the apparent effective width of the GFRP deck and the apparent moment distribution factors - in the context of current AASHTO requirements for steel girder bridges having reinforced concrete decks.

\subsection{APPARENT EFFECTIVE WIDTH}

The apparent effective width of GFRP deck participating in resisting longitudinal flexure in a composite manner with the steel girders is calculated for each bridge in the same manner. The vertical location of the neutral axis of the steel girder resisting the applied vehicle load is determined from at least two strain measurements taken over the depth of the girder. In all cases, the neutral axis was found to be located higher in the section than the mid-depth of the steel beam (which would be the location of the neutral axis if no composite action was present). Knowing the material properties and geometry of the GFRP deck and steel beam, the effective width contributing to the flexural resistance (and thus resulting in the change in neutral axis location) can be calculated for the composite section (see Chapter 1.3.1.1). In this calculation, the effective width is calculated assuming both top and bottom GFRP face plates contribute equally. A sample apparent effective width calculation for the interior girder of the Boyer Bridge

(test 1) is given in Appendix A. The inherent assumptions of this procedure are that all strains are 
in the elastic range and that there is no strain discontinuity at the steel flange-to-GFRP deck interface. The former assumption is certainly valid for the service load levels used; the latter assumption will be discussed further below. Table 3-1 gives a summary of observed apparent effective GFRP deck widths calculated as indicated above and the AASHTO-prescribed (2004) effective width (see Chapter 1.3.1) for a concrete deck having the same depth (195 mm).

Table 3-1: Comparison of AASHTO and Observed Effective Width Values

\begin{tabular}{|c|c|c|c|c|c|}
\hline Bridge & Girder & $\begin{array}{c}\text { Girder } \\
\text { spacing, } S\end{array}$ & $\begin{array}{l}\text { Observed } \\
\text { effective } \\
\text { width }\end{array}$ & $\frac{\text { Observed }}{\text { AASHTO }}$ & $\frac{\text { Observed }}{\text { test } 1}$ \\
\hline \multirow[t]{2}{*}{ Fairground test 1} & Interior & $\begin{array}{l}2847 \mathrm{~mm}^{1} \\
2671 \mathrm{~mm}^{1}\end{array}$ & $2492 \mathrm{~mm}$ & $\begin{array}{l}0.88 \\
0.93\end{array}$ & - \\
\hline & Exterior & $2034 \mathrm{~mm}$ & $1775 \mathrm{~mm}$ & 0.87 & - \\
\hline \multirow[t]{2}{*}{ Fairground test 2} & Interior & $\begin{array}{l}2847 \mathrm{~mm}^{1} \\
2671 \mathrm{~mm}^{1}\end{array}$ & $2975 \mathrm{~mm}$ & $\begin{array}{l}1.04 \\
1.11\end{array}$ & 1.19 \\
\hline & Exterior & $2034 \mathrm{~mm}$ & $1445 \mathrm{~mm}$ & 0.71 & 0.81 \\
\hline \multirow{2}{*}{ Boyer test 1} & Interior & $1754 \mathrm{~mm}$ & $1252 \mathrm{~mm}$ & 0.71 & - \\
\hline & Exterior & $1260 \mathrm{~mm}$ & $1375 \mathrm{~mm}$ & 1.09 & - \\
\hline \multirow{2}{*}{ Boyer test 2} & Interior & $1754 \mathrm{~mm}$ & $1356 \mathrm{~mm}$ & 0.77 & 1.08 \\
\hline & Exterior & $1260 \mathrm{~mm}$ & $1186 \mathrm{~mm}$ & 0.94 & 0.86 \\
\hline \multirow{2}{*}{ Boyer test 3} & Interior & $1754 \mathrm{~mm}$ & $1406 \mathrm{~mm}$ & 0.80 & 1.12 \\
\hline & Exterior & $1260 \mathrm{~mm}$ & $943 \mathrm{~mm}$ & 0.75 & 0.69 \\
\hline \multirow{2}{*}{ Boyer test 4} & Interior & $1754 \mathrm{~mm}$ & n.a. & n.a. & - \\
\hline & Exterior & $1260 \mathrm{~mm}$ & $327 \mathrm{~mm}$ & 0.26 & 0.24 \\
\hline SC S655 test 1 & Interior & $2440 \mathrm{~mm}$ & $1744 \mathrm{~mm}$ & 0.71 & - \\
\hline SC S655 test 2 & Interior & $2440 \mathrm{~mm}$ & $2097 \mathrm{~mm}$ & 0.86 & 1.20 \\
\hline SC S655 test 3 & Interior & $2440 \mathrm{~mm}$ & $1156 \mathrm{~mm}$ & 0.47 & 0.66 \\
\hline
\end{tabular}

${ }^{1} 12$ times the depth of the flange plus one half the width of the top flange of the girder $=2671 \mathrm{~mm}$ per AASHTO (2004) controls effective width in this case. $25.4 \mathrm{~mm}=1$ in.

n.a. $=$ data not available

Generally, the observed effective width is less than that given by AASHTO for a similar concrete deck. The exceptions (Fairground Road Bridge, interior girder, test 2; and Boyer 
Bridge, interior girder, test 1) likely reflect errors in the recorded data since the calculated effective width is greater than the girder spacing.

The discrete, rather than continuous nature of the shear connection for a GFRP deck, appears to contribute to the reduced efficiency of the deck. The Boyer Bridge, which had fewer shear studs at each connection (two, rather than three) and a smaller girder spacing has an apparent effective width of about $1300 \mathrm{~mm}$ ( $75 \%$ of that of an equivalent concrete deck). For the Fairground and SC S655 bridges, both having three studs per connection, the apparent effective widths were on the order of $2500 \mathrm{~mm}$ and $1665 \mathrm{~mm}$, respectively - approximately $80 \%$ of that of an equivalent concrete deck. These results are consistent with the reduced shear connection capacities reported previously for similar three-stud connections (Moon et al. 2002; Turner et al. 2003). Similarly the reduction apparent in the Boyer Bridge is consistent with shear connection capacities reported for similar two-stud connections (Yulismana 2005). Shear lag resulting from the relatively small grouted pocket (as compared to the larger deck panel) will also affect this behavior and result in a smaller effective width. Finally, as demonstrated by Keller et al. (2004), the GFRP deck type used in this study has relatively low in-plane shear stiffness, affecting the ability to fully engage the top face plate as described in Chapter 1.3.2.2.

The impact of the reduced effective width is to increase the stress level carried by the steel girder. Compounding this effect is the fact that the GFRP deck is not as axially stiff as a concrete deck in the first place and will therefore contribute less to composite action in any event.

Also evident in the final column of Table 3-1 is an apparent degradation in available composite action, particularly for exterior girders, as measured by a decrease in apparent effective width over time. In this regard, a thorough inspection of the flange-haunch-deck 
interface of the SC S655 Bridge did not reveal any obvious degradation or interface cracks although all strain and deflection data collected revealed the same significant degradation indicated in Table 3-1 (Turner 2003).

\subsection{MOMENT DISTRIBUTION FACTORS FROM IN-SITU TESTS}

Moment distribution factors were derived from girder strain data and calculated using Equation 1.5. For the SC S655 Bridge, symmetry was assumed in order to obtain strains from the uninstrumented girders (Turner 2003). Confidence in this assumption was developed in two ways. First, similar calculations were made by superimposing symmetric and anti-symmetric load cases (Turner 2003) resulting in similar results for a less critical load case. Secondly, moment distribution calculations based on girder strains and girder deflections yielded uniform results (Turner 2003).

Table 3-2 reports observed moment distribution factors as well as those calculated using standard AASHTO practices. The first column of the table gives the bridge and test number. The second and third columns show the distribution factors calculated according to AASHTO LRFD (2004) and AASHTO Load Factor Design (1996) given in Eq. 1.3 and Eq. 1.4, respectively. The fourth and fifth columns show the distribution factors calculated using the lever rule using both AASHTO-prescribed (2004) load placement (to cause the greatest girder reactions) and the actual load placement from each test (See Figures 2-3 through 2-5). The sixth column of the table shows the value of the moment distribution factor observed from in-situ field tests calculated based on Equation 1.5. The final four columns of the table show the ratio of the observed value to each of the theoretical values. 
Table 3-2: Comparison of AASHTO and Observed Moment Distribution Factor Values

\begin{tabular}{|c|c|c|c|c|c|c|c|c|c|}
\hline \multirow[b]{3}{*}{ Bridge } & \multicolumn{5}{|c|}{ Moment Distribution Factor } & \multicolumn{4}{|c|}{ Ratio of observed value to... } \\
\hline & \multicolumn{2}{|c|}{ AASHTO } & \multicolumn{2}{|c|}{ Lever Rule } & \multirow[b]{2}{*}{ Observed } & \multirow[b]{2}{*}{$\begin{array}{l}\text { (2004) } \\
\text { EQ } 1.3\end{array}$} & \multirow[b]{2}{*}{$\begin{array}{l}\text { (1996) } \\
\text { EQ 1.4 }\end{array}$} & \multirow[b]{2}{*}{$\begin{array}{l}\text { AASHTO } \\
\text { prescribed } \\
\text { geometry }\end{array}$} & \multirow[b]{2}{*}{$\begin{array}{c}\text { based on } \\
\text { geometry } \\
\text { shown in } \\
\text { Figs } 2.3-2.5\end{array}$} \\
\hline & $\begin{array}{l}\text { (2004) } \\
\text { EQ 1.3 }\end{array}$ & $\begin{array}{l}\text { (1996) } \\
\text { EQ 1.4 }\end{array}$ & $\begin{array}{l}\text { AASHTO } \\
\text { prescribed } \\
\text { geometry }\end{array}$ & $\begin{array}{c}\text { based on } \\
\text { geometry } \\
\text { shown in } \\
\text { Figs } 2.3-2.5 \\
\end{array}$ & & & & & \\
\hline Fairground 1 & \multirow{2}{*}{0.756} & \multirow{2}{*}{0.848} & \multirow{2}{*}{0.964} & 0.864 & 0.651 & 0.86 & 0.77 & 0.68 & 0.75 \\
\hline Fairground 2 & & & & 0.738 & 0.676 & 0.89 & 0.80 & 0.70 & 0.78 \\
\hline Boyer 1 & \multirow{3}{*}{0.532} & \multirow{3}{*}{0.523} & \multirow{3}{*}{0.653} & \multirow{3}{*}{0.609} & 0.536 & 1.01 & 1.02 & 0.82 & 0.88 \\
\hline Boyer 2 & & & & & 0.501 & 0.94 & 0.96 & 0.77 & 0.82 \\
\hline Boyer 3 & & & & & 0.523 & 0.98 & 1.00 & 0.80 & 0.86 \\
\hline SC S655 1 & \multirow{3}{*}{0.688} & \multirow{3}{*}{0.727} & \multirow{3}{*}{0.875} & \multirow{3}{*}{0.750} & 0.876 & 1.27 & 1.20 & 1.00 & 1.17 \\
\hline SC S655 2 & & & & & 0.811 & 1.18 & 1.12 & 0.93 & 1.08 \\
\hline SC S655 3 & & & & & 0.777 & 1.13 & 1.07 & 0.89 & 1.04 \\
\hline
\end{tabular}

Moment distribution factors are calculated from test results and are affected by the geometry of the load vehicle and load path used. In the cases of the Fairground and Boyer bridges the following discrepancies from AASHTO-prescribed geometry were present and are believe to affect the calculated values of distribution factor to some extent:

1. The gages (axle width) of the test vehicles (see Figures 2-3 and 2-4) were larger than the $1830 \mathrm{~mm}$ (72 in.) prescribed by AASHTO. Zokaie et al. (1992) report that experimentally observed distribution factors will be lower when the test vehicle gage is larger than that used to calibrate the AASHTO guidelines. This effect may be evident in the Fairground Road Bridge data where the truck gage in test 2, although still larger than $1830 \mathrm{~mm}$, was smaller than that used in test 1 .

2. In both the Fairground and Boyer bridges, the two-truck load case was determined by superimposing adjacent load cases each using a single vehicle. Significantly, the resulting "passing distance” between the trucks was larger, $1372 \mathrm{~mm}$ (54 in.), than the AASHTO 
prescribed, $1220 \mathrm{~mm}$ (48 in.). This increased truck spacing will also result in lower calculated distribution factors (Zokaie et al. 1992).

Therefore, if two vehicles having the correct gage and passing distance were used for the Fairground and Boyer Bridge load tests, larger observed moment distribution factors than those reported in Table 3-2 may be expected. The two-truck load case having a $1220 \mathrm{~mm}$ (4 ft.) passing distance used for the SC S655 Bridge (see Figure 2-5) is consistent with the AASHTO prescribed load case from which moment distribution factors should be calculated.

Considering the forgoing discussion, the observed moment distribution factors for both the Boyer and SC S655 bridges given in Table 3-2 are greater than the AASHTO-prescribed values for comparable depth concrete decks. Thus, using the AASHTO values for concrete decks is unconservative when GFRP decks are used. In both of these cases, the lever rule appears to give a reasonable and appropriately conservative estimate. The observed values for the Fairground Bridge appear to be conservative although this result must be understood in the context of using a loading vehicle having a larger gage and greater passing distance. These effects are compounded again by the larger girder spacing resulting in relatively conservative experimental results. Furthermore, it is also acknowledged that AASHTO distribution factors become more conservative as the girder spacing, S, increases (Eom and Nowak 2001).

The moment distribution factors reported in Table 3-2 appear to reflect the lower transverse flexural stiffness of a GFRP deck as compared to a concrete deck. The lower stiffness in the transverse deck direction should result in less redistribution of force beyond adjacent girders. There is no significant change in the observed distribution factor with the age of the bridge at testing. 


\subsection{IMPLICATIONS FOR NEW CONSTRUCTION USING GFRP DECKS}

The eventual use of GFRP decks for new bridge construction is unclear. Light-weight GFRP decks are attractive for certain applications such as moving spans (bascules, etc.) and bridges located in remote areas where placing a concrete deck may become impractical (Moses

et al. 2005). Currently, there are no AASHTO guidelines for the application of GFRP decks and designers appear to treat these decks as "equivalent to concrete". Based on the observations reported in this study, two recommendations for new construction using GFRP decks can be made:

\subsubsection{Composite Behavior}

Although a degree of composite behavior is evident at service load levels as described in Chapter 3.1, the degree of composite action is less than that attainable with an equivalent concrete deck. Additionally, as discussed in Chapter 1.3.2.1, shear connections between the GFRP deck and steel girder appear to have limit states associated with failure of the deck and the full shear capacity may generally not be attained. Therefore, it is proposed that for the purposes of STRENGTH (AASHTO 2004; see also Chapter 4) design, GFRP decks should not be assumed to act in a composite manner with steel girders.

For SERVICE (AASHTO 2004; see also Chapter 4) level checks, some composite action may be present. Based on the results presented, the degree of composite behavior appears to be less than that attainable by comparable concrete decks and the behavior appears to degrade with time. Therefore, conservatively, composite action may be neglected. For predictive purposes for the MMC GFRP deck, an effective width equal to $75 \%$ of that calculated for a concrete deck having the same depth as the GFRP deck (beff, see Chapter 1.3.1) is appropriate for determining behavior shortly after construction. This value should be reduced to $50 \%$ for long-term behavior. 
The foregoing values are based on the MMC deck tested having two or three studs per connection located at $610 \mathrm{~mm}$ on center.

\subsubsection{Moment Distribution Factors}

GFRP decks are both longitudinally and transversely more flexible than comparable concrete decks. There is insufficient data to accurately determine a relationship for the distribution factors in a form similar to other AASHTO equations. For this reason it is proposed that moment distribution factors may be best estimated using the lever rule. This formulation is appropriately conservative as indicated in Chapter 3.2.

\subsection{IMPLICATIONS FOR REPLACING CONCRETE DECKS WITH GFRP DECKS}

Because of their significantly reduced weight and enhanced durability characteristics, GFRP decks offer a very attractive alternative for bridge deck replacement, particularly in cases where the existing bridge superstructure or substructure is structurally deficient. The reduced dead load of the deck may permit removing posting or increasing the rating of a bridge. Additionally, GFRP decks may allow similar enhancements for historic bridges without requiring additional structural retrofit, which may affect the historic fabric of the bridge. Nonetheless, there are implications of the reduced apparent effective width and increased distribution factors discussed in the previous sections.

The primary consideration when replacing composite concrete bridge decks using GFRP decks is that the supporting girders will be required to support increased live load stresses. This increase results both from the decreased composite action and increased distribution factors (resulting in decreased transverse distribution of forces). Although the dead load stress will likely be reduced, the live load stress is transient and thus represents the stress range considered for 
fatigue sensitive details. This increased stress range must be considered if fatigue-prone details are present.

The decreased composite action available when a GFRP deck is installed also has the effect of increasing compressive stresses in the steel girder since the neutral axis is effectively lower. As such, compression flange and web region stress conditions change and slenderness and stability effects must be considered.

Current practice is generally to assume that no composite action between a GFRP deck and steel girder is available and that the girders must resist flexural loads in a non-composite manner. The results of the present study support this practice. Particularly the apparent degradation in composite action (as measured by effective deck width given in Table 3-1) over the course of only a few years in the Boyer and SC S655 bridges indicates that composite action should not be considered for the STRENGTH (AASHTO 2004) load cases when GFRP decks are used to replace concrete decks, regardless of the original structural condition. Similar to the discussion in Chapter 3.3.1, composite action may be considered for SERVICE (AASHTO 2004) load checks, although the composite action will be significantly reduced from that of a comparable concrete deck and may be conservatively neglected altogether.

Distribution factors may also increase when a GFRP deck is used in place of a concrete deck. This increase results in girders adjacent the wheel paths carrying proportionally greater loads than would be the case were a concrete deck used. The implication of this in existing structures is that, once again, stress levels in the girders will increase. Bridge geometry (girder spacing and location of girders relative to travel lanes) will have a significant influence on this effect. Similar to new construction, use of the lever rule to determine distribution factors is appropriately conservative for GFRP decks. 


\subsection{ILLUSTRATIVE EXAMPLE - SUPERSTRUCTURE STRESSES}

In a bridge deck replacement scenario, a concrete deck may be replaced with a GFRP deck. The original concrete deck may be composite with the underlying steel girders or noncomposite. Similarly, the GFRP deck may be composite or non-composite. Certainly by replacing a concrete deck with a GFRP deck, the structural weight (dead load) is reduced. Nonetheless, as a result of the observed decreased composite action and the increased

distribution factors discussed in Chapter 3, the resulting stresses in the supporting girders may increase. As will be shown in the following sections, this is particularly the case for the compression flange of the supporting girder. The magnitude of live loads are unaffected by the deck replacement. Again, however, resulting live load transient stresses in the supporting girders are increased due to the reduced composite action and the increased distribution factors. This increased stress range must be considered if fatigue-prone details are present. The following sections present an illustrative example, based on the geometry of the South Carolina SC655 Bridge, which assesses girder stresses prior to and after the replacement of an existing concrete deck.

\subsection{PROTOTYPE BRIDGE SECTIONAL PROPERTIES}

Table 4-1 lists material properties and resulting member properties for a single interior girder for the example bridge. The example is based on the SC655 Bridge (Turner et al. 2004) reported in Section 2.4. Four cases were considered in evaluating the stress range and live load 
capacity of the example bridge. The first case represents a $216 \mathrm{~mm}$ (8.5 in.) thick concrete deck acting compositely with the underlying W36x150 steel girders. Case 2 represents the same 216 mm (8.5 in.) concrete deck acting in a non-composite manner. The third case represents a 195 mm (7.66 in.) thick MMC GFRP deck acting compositely with the underlying girders. The fourth case represents the same $195 \mathrm{~mm}$ (7.66 in.) thick GFRP deck acting non-compositely with the underlying girders. All cases had a 25 mm (1 in.) thick grout haunch between the deck soffit and girder.

As a point of clarification, the S655 Bridge was not a deck replacement. The designers of the S655 Bridge assumed the behavior to be represented by Case 3: the GFRP deck acting compositely with the girders. Nonetheless, the girders are detailed to satisfy the requirements of Case 2 in the event that the GFRP deck needed to be replaced. In South Carolina, such a rapid deck replacement would be carried out using a precast concrete deck and no composite action would be provided for. 
Table 4-1: Material and Member Properties

\begin{tabular}{|c|c|c|c|c|}
\hline Material Properties & $\begin{array}{l}\text { Case } 1 \text { - Concrete } \\
\text { Composite }\end{array}$ & $\begin{array}{l}\text { Case } 2 \text { - Concrete } \\
\text { Non-composite }\end{array}$ & $\begin{array}{l}\text { Case } 3 \text { - GFRP } \\
\text { Composite }\end{array}$ & $\begin{array}{l}\text { Case } 4 \text { - GFRP } \\
\text { Non-Composite }\end{array}$ \\
\hline Deck wt., kPa (psf) & $5.08^{1}(106)$ & $5.08^{1}(106)$ & $0.96^{2}(20)$ & $0.96^{2}(20)$ \\
\hline $\mathrm{E}_{\text {steel, }}, \mathrm{GPa}(\mathrm{ksi})$ & $200(29,000)$ & $200(29,000)$ & $200(29,000)$ & $200(29,000)$ \\
\hline $\mathrm{E}_{\text {grout }}, \mathrm{GPa}(\mathrm{ksi})^{3}$ & $24.9(3,605)$ & $24.9(3,605)$ & $24.9(3,605)$ & $24.9(3,605)$ \\
\hline $\mathrm{E}_{\text {concrete }}, \mathrm{GPa}(\mathrm{ksi})^{3}$ & $24.9(3,605)$ & $24.9(3,605)$ & N/A & $\mathrm{N} / \mathrm{A}$ \\
\hline $\mathrm{E}_{\mathrm{FRP}}, \mathrm{GPa}(\mathrm{ksi})^{2}$ & $\mathrm{~N} / \mathrm{A}$ & $\mathrm{N} / \mathrm{A}$ & $13.3(1,923)$ & $13.3(1,923)$ \\
\hline $\mathrm{n}_{1}=\mathrm{E}_{\text {steel }} / \mathrm{E}_{\mathrm{FRP}}$ & N/A & N/A & 15.1 & 15.1 \\
\hline $\mathrm{n}_{2}=\mathrm{E}_{\text {steel }} / \mathrm{E}_{\text {grout }}=\mathrm{E}_{\text {steel }} / \mathrm{E}_{\text {concrete }}$ & 8.0 & 8.0 & 8.0 & 8.0 \\
\hline $\mathrm{b}_{\mathrm{eff}}, \mathrm{mm}(\mathrm{in})$ & $2,438(96)$ & $2,438(96)$ & $0.75 \times 2438=1,829(72)$ & $0.75 \times 2438=1,829(72)$ \\
\hline $\mathrm{DF}$ & $\begin{array}{c}0.688 \\
\text { (Eq. 1.3) }\end{array}$ & $\begin{array}{c}0.688 \\
\text { (Eq. 1.3) }\end{array}$ & $\begin{array}{c}0.875 \\
\text { (lever rule) }\end{array}$ & $\begin{array}{c}0.875 \\
\text { (lever rule) }\end{array}$ \\
\hline \multicolumn{5}{|l|}{ Member Properties } \\
\hline $\mathrm{I}_{\mathrm{x}}\left(\mathrm{I}_{\mathrm{tr}}\right.$ for composite $), \mathrm{mm}^{4}\left(\mathrm{in}^{4}\right)$ & $1.09 \times 10^{10} \quad(26,260)$ & $3.76 \times 10^{10}(9,040)$ & $5.13 \times 10^{10} \quad(12,332)$ & $3.76 \times 10^{10}(9,040)$ \\
\hline $\mathrm{M}_{\mathrm{p}}, \mathrm{kN} \cdot \mathrm{m}(\mathrm{kip} \cdot \mathrm{ft})$ & $6,018(4,438)$ & $3,283(2,421)$ & $\begin{array}{c}5,028(3,690) \\
\text { see Section 4.1.1 }\end{array}$ & $3,283(2,421)$ \\
\hline $\mathrm{y}_{\mathrm{top}}, \mathrm{mm}$ (in) & $44(1.74)$ & 456 (17.95) & 372 (14.66) & 456 (17.95) \\
\hline $\mathrm{y}_{\text {bot }}, \mathrm{mm}$ (in) & $868(34.16)$ & 456 (17.95) & $540(21.24)$ & 456 (17.95) \\
\hline
\end{tabular}

${ }^{1}$ density of concrete assumed to be $2400 \mathrm{~kg} / \mathrm{m}^{3}$ (150 pcf)

2 Turner et al. (2004)

${ }^{3}$ calculated per ACI (2005) based on $\mathrm{f}_{\mathrm{c}}{ }^{\prime}=27.6 \mathrm{MPa}(4,000 \mathrm{psi})$; grout and concrete assumed to be the same material

For the composite cases, Case 1 and Case 3, composite section properties were derived using simple mechanics (See Figs. 4.1-2). For Case 1, the neutral axis of the composite section was calculated using an effective width for the concrete slab of 2,438 mm (96 in.), equal to the girder spacing. For Case 3, as recommended in Section 3.4, an effective width of $75 \%$ of the Case 1 value, or $1829 \mathrm{~mm}$ (72 in.) was used. The distribution factor (Table 4-1) used for subsequent load calculations was determined from Eq. 1.3 for the concrete decks (Cases 1 and 2) and using the lever rule, as recommended in Section 3.4, for the GFRP decks (Cases 3 and 4). Both the grout haunch and concrete deck were assumed to have a compressive strength, $\mathrm{f}_{\mathrm{c}}$, of 27.6 MPa (4,000 psi). The reported compressive strength of the GFRP deck was 172.4 MPa (25 ksi) and the compressive failure strain was 0.013 (Turner et al. 2004), resulting in a compressive 
modulus, $\mathrm{E}_{\mathrm{FRP}}$ equal to $13.3 \mathrm{GPa}(1,923 \mathrm{ksi})$ (Table 4-1). Once the neutral axis was located, the transformed moment of inertia for the composite section was calculated. This process is tabulated in Appendix B-1 Tables B-1 \& B-2. 


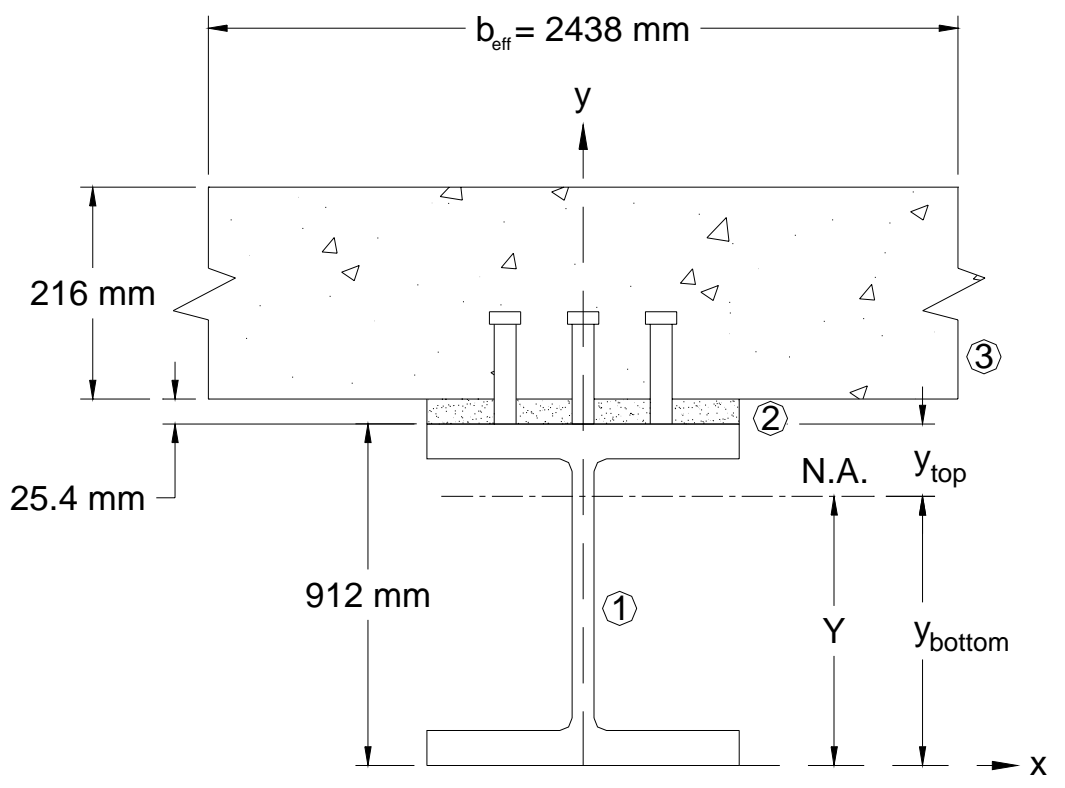

Figure 4-1: Cross-section of Composite Beam (Case 1)

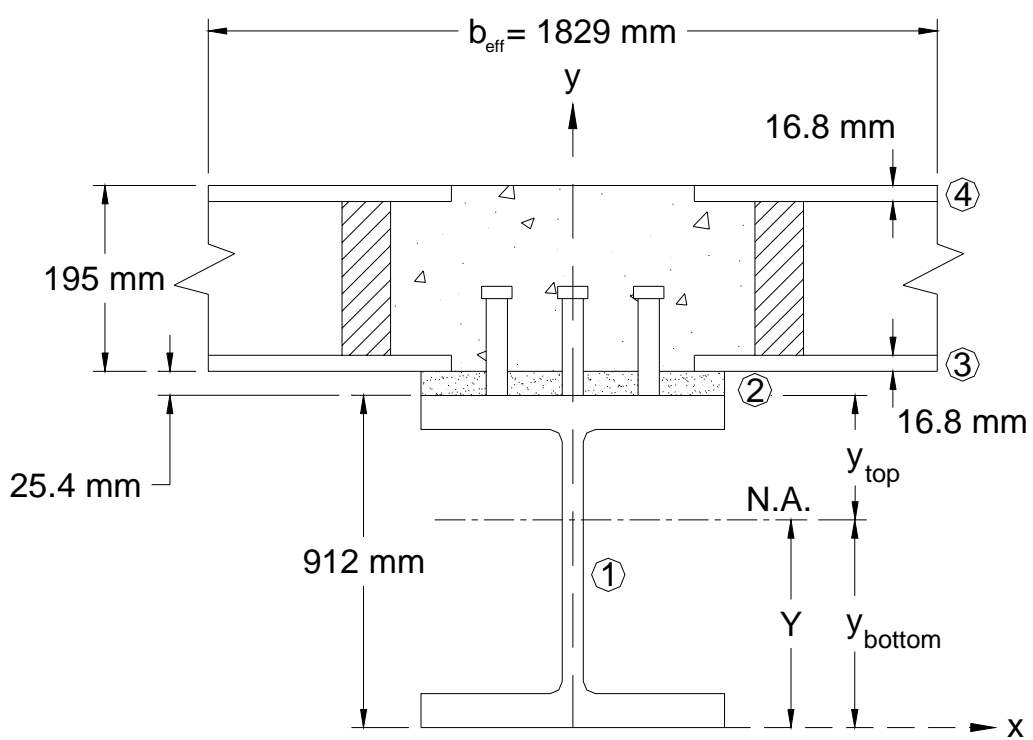

Figure 4-2: Cross-section of Composite Beam (Case 3) 
The plastic moment capacity, $\mathrm{M}_{\mathrm{p}}$, for the non-composite cases, Cases $2 \& 4$, was simply calculated by multiplying the plastic section modulus of the W36 beam, $Z_{x}$, by the yield stress of the beam, $\mathrm{F}_{\mathrm{y}}$. This yielded a value for plastic moment capacity of 3,283 $\mathrm{kN} \cdot \mathrm{m}(2,421 \mathrm{kip} \cdot \mathrm{ft})$ for Cases $2 \& 4$ (See Table 4-1). The calculation of plastic moment capacity for the composite cases was a little more involved. For Case 1, the location of the plastic neutral axis (PNA) was determined in the traditional manner for steel-concrete composite sections, assuming the Whitney rectangular stress distribution applied to the slab cross section and a critical concrete strain of 0.003 . For Case 1 , the value of the plastic moment capacity was determined to be 6,018 $\mathrm{kN} \cdot \mathrm{m}(4,438 \mathrm{kip} \cdot \mathrm{ft})$ (See Table 4-1). The aforementioned calculations are shown in App. B-1.

\subsubsection{Plastic Moment Calculation for Composite GFRP Case}

The calculation of plastic moment capacity is further complicated for Case 3. Because GFRP behaves in a linear elastic manner to failure, the compressive stress in the bottom face sheet of the GFRP deck does not equal the compressive stress in the top face sheet. Rather the stress distribution through the deck reflects the assumed linear strain distribution. In order to determine the section capacity, the strain in the top face sheet is assumed to be at its ultimate value (see calculations below). The PNA is then selected and the stresses through the section are calculated and the net axial force on the section is determined. The location of the neutral axis is iterated upon until the net axial force equals zero. And thus the PNA, corresponding to the peak GFRP strain, is determined and the corresponding plastic moment capacity may be calculated.

The GFRP face sheets are relatively thin and the top face sheet is only supported at discrete lines (the webs) perpendicular to the applied compressive stress field. Therefore, buckling of the top face plate is possible. Thus, before continuing the calculation of the plastic moment capacity, the ultimate compressive stress of the top face sheet (and thus, the 
corresponding strain) must be determined accounting for the effective length between web supports. The top face sheet is supported by the deck webs at alternating spacings of 170 (5.7 in.) and $135 \mathrm{~mm}$ (5.3 in.) (see Figure 2-1). For the purposes of this calculation, the longer effective length is used.

The loading geometry of the top face sheet is shown in Figure 4-3. The choice of the width of the section, $\mathrm{b}$, is not relevant since, in the calculation of $r=\sqrt{I / A}$, the $\mathrm{b}$ terms cancel. The critical buckling stress is calculated as:

$$
\sigma_{c r}=\frac{\pi^{2} E}{(k L / r)^{2}}
$$

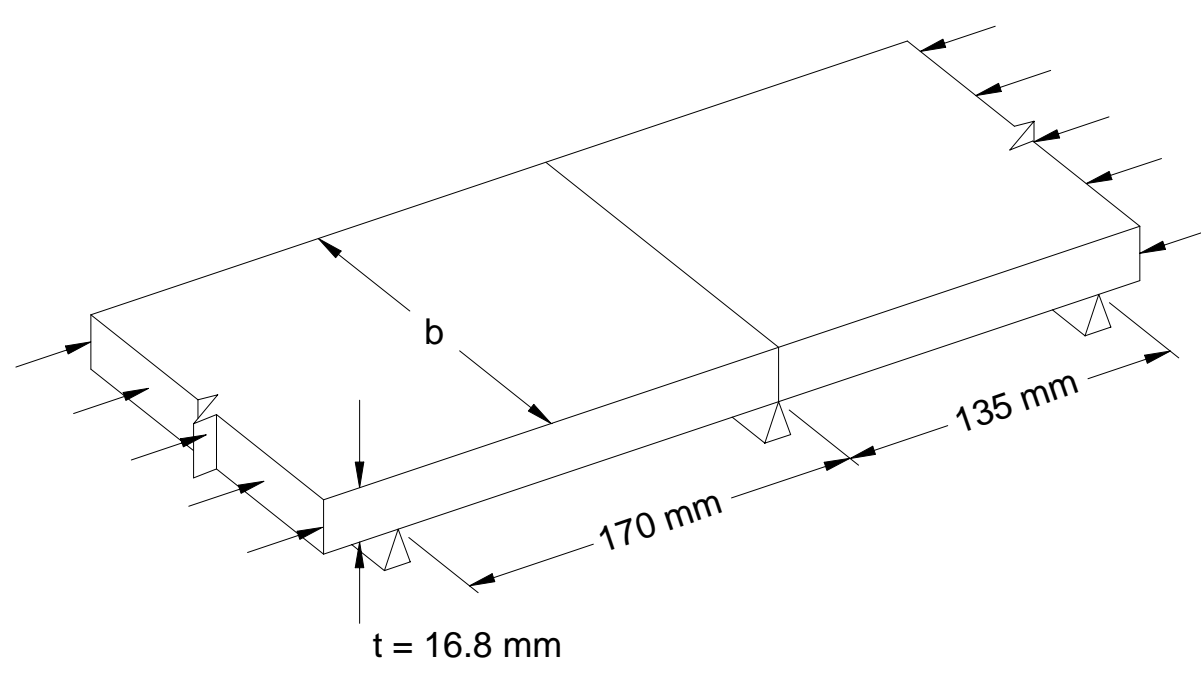

Figure 4-3: Loading Condition of Top Face Plate

Although it is slightly conservative, the webs are assumed to only provide a "simple" support; therefore, the value of $\mathrm{k}=1$ is selected. Solving Equation 4.1, the critical stress for the top plate may be found to $105.5 \mathrm{MPa}(15.3 \mathrm{ksi})$. The corresponding ultimate strain is 0.008 . This latter value is used as the top face sheet strain in the determination of the plastic capacity of the composite GFRP deck section (Case 3). 
The strain at the bottom face sheet is denoted by $\varepsilon_{\mathrm{b}}$ and the plastic neutral axis is denoted as $y$ in Fig. 4-4. The stresses for each section were arrived at by utilizing Hooke's Law, $\sigma=E \cdot \varepsilon$. The forces at each section were then found by multiplying the stress by the cross sectional area. All forces above the PNA are compressive forces, and all forces below the PNA are tensile forces.

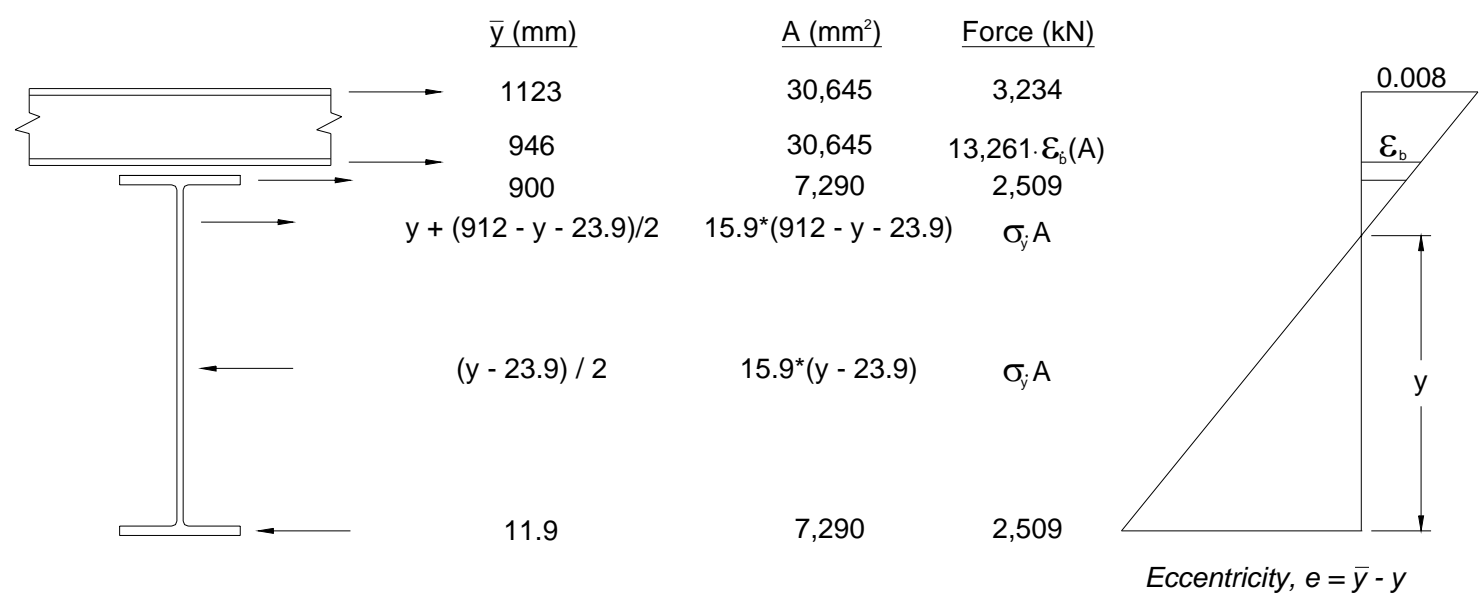

Figure 4-4: Determination of Plastic Section

As a sample calculation, illustrated in Figure 4-4, assume that the plastic neutral axis is $762 \mathrm{~mm}$ (30 in.) above the base of the steel beam, i.e. $\mathrm{y}=762 \mathrm{~mm}$. The top face sheet strain is set at 0.008 which corresponds to a value of $\varepsilon_{\mathrm{b}}=0.004$. The compressive force in the top face sheet is then:

$$
A \cdot \sigma=(1829 \mathrm{~mm}) \cdot(16.76 \mathrm{~mm}) \cdot(105.5 \mathrm{MPa})=3234 \mathrm{kN}
$$

The compressive force in the bottom face sheet is:

$$
A \cdot E \cdot \varepsilon_{b}=(1829 \mathrm{~mm}) \cdot(16.76 \mathrm{~mm}) \cdot(13.26 \mathrm{GPa}) \cdot 0.004=1,628 \mathrm{kN}
$$


The compressive force in the top flange of the steel member (whose strain is 0.003) is:

$A \cdot \sigma=(305 \mathrm{~mm}) \cdot(24 \mathrm{~mm}) \cdot(344.7 \mathrm{MPa})=2509 \mathrm{kips}$

Similarly, the tensile force at the bottom flange of the steel member is:

$A \cdot \sigma=(305 \mathrm{~mm}) \cdot(24 \mathrm{~mm}) \cdot(344.7 \mathrm{MPa})=2509 \mathrm{kN}$

At this point in the calculation, it can be seen that the net axial force on the section will be compressive since the web is only able to provide $4,804 \mathrm{kN}$ (1,080 kips) if it is acting entirely in tension (which it is not in this sample calculation). Thus the selection of the PNA, $y=762 \mathrm{~mm}$ (30 in.) is too low. A new value for the PNA is selected and the calculations repeated until the net axial force on the section is equal to zero.

Through trial and error, the location of the PNA is found to be $y=856 \mathrm{~mm}$ (33.7 in.). The plastic moment capacity for the section can then be calculated by taking a summation of the force components multiplied by their distance to the PNA (See Table 4-2). This results in a plastic moment capacity of 5,030 $\mathrm{kN} \cdot \mathrm{m}(3,690 \mathrm{kip} \cdot \mathrm{ft})$. As expected, this value lies between the non-composite capacity of the W36x150 alone (Cases 2 and 4) and the composite capacity calculated assuming a stiffer concrete deck (Case 1).

Table 4-2: Plastic Moment Capacity Calculation

\begin{tabular}{|c|cc|cc|cc|}
\hline & \multicolumn{2}{|c|}{$\begin{array}{c}\text { Force, F } \\
\text { kN }\end{array}$} & \multicolumn{2}{c|}{$\begin{array}{c}\text { Eccentricity, e } \\
\text { mm (kips) }\end{array}$} & \multicolumn{2}{c|}{ F*e - kN·m (kip·ft) } \\
\hline Top face sheet & 3,234 & $(727)$ & 267.5 & $(10.53)$ & 864.9 & $(637.9)$ \\
Bottom face sheet & 1,112 & $(250)$ & 89.7 & $(3.53)$ & 99.7 & $(73.5)$ \\
Top flange steel & 2,509 & $(564)$ & 43.9 & $(1.73)$ & 110.2 & $(81.3)$ \\
Web (Comp.) & 191 & $(43)$ & 17.3 & $(0.68)$ & 3.3 & $(2.4)$ \\
Steel Web (Tens.) & $-4,541$ & $(-1,021)$ & -414.8 & $(-16.33)$ & $1,883.7$ & $(1,389.4)$ \\
Bottom flange steel & $-2,509$ & $(-564)$ & -823.7 & $(-32.43)$ & $2,066.4$ & $(1,524.2)$ \\
\hline
\end{tabular}




\subsection{APPLIED LOADING AND LOAD CASES}

Complete load calculations are presented in Appendix B-2. The loads applied to the structure were determined based on the 2004 AASHTO LRFD Specification. The prescribed dead loads: DC, the load due to bridge components and DW, the load due to the wearing surface (assumed to be $38 \mathrm{~mm}$ (1.5 in.) of asphalt overlay), were calculated and distributed evenly to each of the five supporting girders. From these uniformly distributed loads, the maximum dead load moments were calculated. The live load (LL) was based on AASHTO H25 design loading. The load was placed longitudinally on the span to yield the maximum live load moment (see Appendix B-2). The distribution factors (DF) given in Table 4-1 are applied to all live load cases. Three AASHTO load cases are considered: STRENGTH I, SERVICE I and FATIGUE (AASHTO 2004 - Table 3.4.1-1). The load combinations and resulting design moments for an interior girder are presented in Table 4-3. As an illustrative example, only the interior girders are considered in this discussion. 
Table 4-3: Design Loading and Moments (see Appendix B-2 for details)

\begin{tabular}{|c|c|c|c|c|c|c|}
\hline & \multicolumn{2}{|l|}{ Loading } & \multicolumn{2}{|c|}{$\begin{array}{l}\text { Cases } 1 \text { \& } 2 \text { - } \\
\text { Concrete Deck }\end{array}$} & \multicolumn{2}{|c|}{$\begin{array}{l}\text { Cases } 3 \& 4 \text { - } \\
\text { GFRP Deck }\end{array}$} \\
\hline & \multirow{4}{*}{$\begin{array}{l}\text { Dead Load of Components } \\
\text { DC - kN/m (kips/ft) }\end{array}$} & Deck & 12.40 & $(0.850)$ & 2.34 & $(0.160)$ \\
\hline & & Girder & 2.19 & $(0.150)$ & 2.19 & $(0.150)$ \\
\hline & & Parapet & 2.38 & $(0.163)$ & 2.38 & $(0.163)$ \\
\hline & & Diaphragms & 0.18 & $(0.012)$ & 0.18 & $(0.012)$ \\
\hline & $\begin{array}{l}\text { Dead Load of Wearing Surface } \\
\text { DW - kN/m (kips/ft) }\end{array}$ & $\begin{array}{l}\text { 38mm (1.5") } \\
\text { Asphalt } \\
\text { Wearing } \\
\text { Surface } \\
\end{array}$ & 2.19 & $(0.150)$ & 2.19 & $(0.150)$ \\
\hline & Live Load & & \multicolumn{2}{|c|}{ H25 } & \multicolumn{2}{|c|}{ H25 } \\
\hline & \multicolumn{6}{|l|}{ Moments } \\
\hline & \multicolumn{2}{|l|}{$\begin{array}{l}\mathrm{M}_{\mathrm{DC}}-\mathrm{kN} \cdot \mathrm{m} \quad(\mathrm{kip}-\mathrm{ft}) \\
\mathrm{M}_{\mathrm{DW}}-\mathrm{kN} \cdot \mathrm{m} \quad(\mathrm{kip}-\mathrm{ft}) \\
\mathrm{M}_{\mathrm{LL}}-\mathrm{kN} \cdot \mathrm{m} \quad(\mathrm{kip}-\mathrm{ft})\end{array}$} & $\begin{array}{c}658.5 \\
84.1 \\
606.9 \\
\end{array}$ & $\begin{array}{l}(485.6) \\
(62.0) \\
(447.6) \\
\end{array}$ & $\begin{array}{c}271.8 \\
84.1 \\
772.0 \\
\end{array}$ & $\begin{array}{c}(200.4) \\
(62.0) \\
(569.3) \\
\end{array}$ \\
\hline STRENGTH I & \multicolumn{2}{|c|}{$\begin{array}{c}\mathrm{M}_{\mathrm{u}}=1.75\left(1.33 * \mathrm{M}_{\mathrm{LL}}\right)+1.25 \mathrm{M}_{\mathrm{DC}}+1.5 \mathrm{M}_{\mathrm{DW}} \\
\mathrm{kN} \cdot \mathrm{m} \text { (kip-ft) }\end{array}$} & $2,361.9$ & $(1,741.8)$ & $2,262.6$ & $(1,668.6)$ \\
\hline SERVICE 1 & \multicolumn{2}{|c|}{$\begin{array}{c}\mathrm{M}_{\mathrm{u}}=1.00\left(1.33 * \mathrm{M}_{\mathrm{LL}}\right)+1.00 \mathrm{M}_{\mathrm{DC}}+1.00 \mathrm{M}_{\mathrm{DW}} \\
\mathrm{kN} \cdot \mathrm{m} \text { (kip-ft) }\end{array}$} & $1,549.8$ & $(1,142.9)$ & $1,382.6$ & $(1,019.6)$ \\
\hline FATIGUE & \multicolumn{2}{|c|}{$\mathrm{kN} \cdot \mathrm{m} \quad(\mathrm{kip}-\mathrm{ft})$} & 523.5 & (386.1) & 665.8 & (491.0) \\
\hline
\end{tabular}




\subsection{STRESSES IN STEEL GIRDERS}

Once the dead and live load moments were calculated for each case, they were used to determine the stress in the top and bottom flanges of the W36x150 girders. The stress at the extreme fibers of the girder is arrived at by using the equation:

$$
\sigma=\frac{M y}{I_{x}}
$$

Where, $\sigma=$ stress at location $\mathrm{y}$

$$
\begin{aligned}
& M=\text { applied moment (Table 4-3) } \\
& y=\text { distance from neutral axis to extreme fiber ( } y_{\text {top }} \text { and } y_{\text {bot }} \text { from Table 4-1) } \\
& I=\text { moment of inertia of section (Table 4-1) }
\end{aligned}
$$

Stresses due to dead and live loads, in addition to total stresses were calculated at the extreme tensile and compressive fibers for each of the three load cases considered. The results are tabulated in Tables 4-4 through 4-6. In all cases, moments corresponding to DC loads are applied to the non-composite steel girder section. DW and LL loads are applied to the composite (Cases 1 and 3) or non-composite (Cases 2 and 4) section as appropriate. 
Table 4-4: Calculated Stress Ranges - STRENGTH I

\begin{tabular}{|c|c|cc|cc|cc|cc|}
\hline & & \multicolumn{2}{|c|}{$\begin{array}{c}\text { Case 1 - Concrete } \\
\text { Composite }\end{array}$} & \multicolumn{2}{c|}{$\begin{array}{c}\text { Case 2 - Concrete } \\
\text { Non-composite }\end{array}$} & \multicolumn{2}{c|}{$\begin{array}{c}\text { Case 3 - GFRP } \\
\text { Composite }\end{array}$} & \multicolumn{2}{c|}{$\begin{array}{c}\text { Case 4 - GFRP } \\
\text { Non-Composite }\end{array}$} \\
\hline Extreme Fiber & LL & $\mathbf{- 5 . 7}$ & $\mathbf{( - 0 . 8 3 )}$ & $\mathbf{- 1 7 1 . 2}$ & $\mathbf{( - 2 4 . 8 2 )}$ & $\mathbf{- 1 3 0 . 3}$ & $\mathbf{( - 1 8 . 9 0 )}$ & $\mathbf{- 2 1 7 . 7}$ & $\mathbf{( - 3 1 . 5 7 )}$ \\
Compressive Stress & DC & -99.7 & $\mathbf{( - 1 4 . 4 6 )}$ & -99.7 & $\mathbf{( - 1 4 . 4 6 )}$ & -41.2 & $\mathbf{( - 5 . 9 7 )}$ & -41.2 & $\mathbf{( - 5 . 9 7 )}$ \\
Top Flange & DW & -0.5 & $\mathbf{( - 0 . 0 7 )}$ & -15.3 & $\mathbf{( - 2 . 2 2 )}$ & -9.1 & $\mathbf{( - 1 . 3 3 )}$ & -15.3 & $\mathbf{( - 2 . 2 2 )}$ \\
MPa (ksi) & Total & -105.5 & $\mathbf{( - 1 5 . 2 9 )}$ & -270.9 & $\mathbf{( - 3 9 . 2 9 )}$ & -171.5 & $\mathbf{( - 2 4 . 8 7 )}$ & -258.9 & $\mathbf{( - 3 7 . 5 4 )}$ \\
\hline Extreme Fiber & LL & $\mathbf{1 1 2 . 1}$ & $\mathbf{( 1 6 . 2 6 )}$ & $\mathbf{1 7 1 . 2}$ & $\mathbf{( 2 4 . 8 2 )}$ & $\mathbf{1 8 8 . 9}$ & $\mathbf{( 2 7 . 3 9 )}$ & $\mathbf{2 1 7 . 7}$ & $\mathbf{( 3 1 . 5 7 )}$ \\
Tensile Stress & DC & 99.7 & $\mathbf{( 1 4 . 4 6 )}$ & 99.7 & $\mathbf{( 1 4 . 4 6 )}$ & 41.2 & $\mathbf{( 5 . 9 7 )}$ & 41.2 & $\mathbf{( 5 . 9 7 )}$ \\
Bottom Flange & DW & 10.0 & $\mathbf{( 1 . 4 5 )}$ & 15.3 & $\mathbf{( 2 . 2 2 )}$ & 13.3 & $\mathbf{( 1 . 9 2 )}$ & 15.3 & $\mathbf{( 2 . 2 2 )}$ \\
MPa (ksi) & Total & 211.9 & $\mathbf{( 3 0 . 7 3 )}$ & 270.9 & $\mathbf{( 3 9 . 2 9 )}$ & 230.0 & $\mathbf{( 3 3 . 3 6 )}$ & 258.9 & $\mathbf{( 3 7 . 5 4 )}$ \\
\hline
\end{tabular}

Table 4-5: Calculated Stress Ranges - SERVICE I

\begin{tabular}{|c|c|cc|cc|cc|cc|}
\hline & & \multicolumn{2}{|c|}{$\begin{array}{c}\text { Case 1 - Concrete } \\
\text { Composite }\end{array}$} & \multicolumn{2}{c|}{$\begin{array}{c}\text { Case 2 - Concrete } \\
\text { Non-composite }\end{array}$} & \multicolumn{2}{c|}{$\begin{array}{c}\text { Case 3 - GFRP } \\
\text { Composite }\end{array}$} & \multicolumn{2}{c|}{$\begin{array}{c}\text { Case 4 - GFRP } \\
\text { Non-Composite }\end{array}$} \\
\hline Extreme Fiber & LL & $\mathbf{- 3 . 3}$ & $\mathbf{( - 0 . 4 7 )}$ & $\mathbf{- 9 7 . 8}$ & $\mathbf{( - 1 4 . 1 8 )}$ & $-\mathbf{- 7 4 . 5}$ & $\mathbf{( - 1 0 . 8 0 )}$ & $\mathbf{- 1 2 4 . 4}$ & $\mathbf{( - 1 8 . 0 4 )}$ \\
Compressive Stress & DC & -79.8 & $\mathbf{( - 1 1 . 5 7 )}$ & -79.8 & $\mathbf{( - 1 1 . 5 7 )}$ & -32.9 & $\mathbf{( - 4 . 7 8 )}$ & -32.9 & $\mathbf{( - 4 . 7 8 )}$ \\
Top Flange & DW & -0.3 & $(-0.05)$ & -10.2 & $(-1.48)$ & -6.1 & $(-0.88)$ & -10.2 & $\mathbf{( - 1 . 4 8 )}$ \\
MPa (ksi) & Total & -83.1 & $\mathbf{( - 1 2 . 0 4 )}$ & -177.6 & $\mathbf{( - 2 5 . 7 6 )}$ & -107.4 & $\mathbf{( - 1 5 . 5 8 )}$ & -157.3 & $\mathbf{( - 2 2 . 8 2 )}$ \\
\hline Extreme Fiber & LL & $\mathbf{6 4 . 1}$ & $\mathbf{( 9 . 2 9 )}$ & $\mathbf{9 7 . 8}$ & $\mathbf{( 1 4 . 1 8 )}$ & $\mathbf{1 0 7 . 9}$ & $\mathbf{( 1 5 . 6 5 )}$ & $\mathbf{1 2 4 . 4}$ & $\mathbf{( 1 8 . 0 4 )}$ \\
Tensile Stress & DC & 79.8 & $(11.57)$ & 79.8 & $\mathbf{( 1 1 . 5 7 )}$ & 32.9 & $\mathbf{( 4 . 7 8 )}$ & 32.9 & $\mathbf{( 4 . 7 8 )}$ \\
Bottom Flange & DW & 6.7 & $(0.97)$ & 10.2 & $(1.48)$ & 8.8 & $(1.28)$ & 10.2 & $(1.48)$ \\
MPa (ksi) & Total & 143.9 & $\mathbf{( 2 0 . 8 6 )}$ & 177.6 & $\mathbf{( 2 5 . 7 6 )}$ & 140.8 & $\mathbf{( 2 0 . 4 2 )}$ & 157.3 & $\mathbf{( 2 2 . 8 2 )}$ \\
\hline
\end{tabular}

Table 4-6: Calculated Stress Ranges - FATIGUE

\begin{tabular}{|c|c|c|c|c|c|c|c|c|c|}
\hline & & \multicolumn{2}{|c|}{$\begin{array}{l}\text { Case } 1 \text { - Concrete } \\
\text { Composite }\end{array}$} & \multicolumn{2}{|c|}{$\begin{array}{c}\text { Case } 2 \text { - Concrete } \\
\text { Non-composite }\end{array}$} & \multicolumn{2}{|c|}{$\begin{array}{c}\text { Case } 3 \text { - GFRP } \\
\text { Composite }\end{array}$} & \multicolumn{2}{|c|}{$\begin{array}{c}\text { Case } 4 \text { - GFRP } \\
\text { Non-Composite }\end{array}$} \\
\hline $\begin{array}{c}\text { Extreme Fiber } \\
\text { Compressive Stress } \\
\text { Top Flange } \\
\text { MPa (ksi) }\end{array}$ & $\mathbf{L L}$ & -2.1 & $(-0.31)$ & -63.4 & $(-9.20)$ & -48.3 & $(-7.00)$ & -80.7 & $(-11.70)$ \\
\hline $\begin{array}{c}\text { Extreme Fiber } \\
\text { Tensile Stress } \\
\text { Bottom Flange } \\
\text { MPa (ksi) }\end{array}$ & $\mathbf{L L}$ & 41.6 & $(6.03)$ & 63.4 & (9.20) & 70.0 & (10.15) & 80.7 & (11.70) \\
\hline
\end{tabular}


There are some important aspects to consider when looking at the theoretical stresses. First and foremost, the stresses computed for Case 1 are assuming original conditions. It is unlikely that a perfectly functioning composite concrete deck is going to be replaced. Bridge decks that are in need of replacement are generally in poor condition. There can be a number of issues that cause pre-replacement stresses to vary considerably from the theoretical values. For instance, there can be significant section loss to the steel girders due to deterioration. The deck may be heavily damaged and heavy spalling of the concrete deck can occur, which decreases the deck sectional area and can decrease the degree of composite behavior of the girder-deck system. In an extreme case, a concrete deck designed to act compositely with the underlying stringers may actually exhibit behavior similar to a non-composite situation. 


\subsection{RETROFIT SCENARIOS}

In practice, the following retrofit scenarios are possible:

Scenario A: Composite concrete deck replaced w/ composite GFRP deck - Case 1 to Case 3.

Scenario B: Composite concrete deck replaced w/ non-comp. GFRP deck - Case 1 to Case 4.

Scenario C: Non-comp. concrete deck replaced w/ non-comp. GFRP deck - Case 2 to Case 4.

Scenario D: Non-comp. concrete deck replaced w/ composite GFRP deck - Case 2 to Case 3.

Scenario E: Concrete deck replaced with concrete deck (composite or non-composite).

Scenario E is beyond the scope of the present discussion and will not be considered further. Scenario A is the case typically considered for concrete deck replacement when GFRP decks are to be used. Scenario B, on the other hand, is the scenario recommended in the present work since it is proposed that composite action cannot be fully developed (see Section 3.4). Scenario C may occur in practice when the concrete deck to be replaced is non-composite with its supporting members. This may be the case when replacing a concrete deck supported on floor beams spanning between main girders. Finally, Scenario D is unlikely in practice and will not be considered further in this discussion. Table 4-7 shows the ratios of girder stresses following deck replacement to those prior to deck replacement for Scenarios A, B, and C. 
Table 4-7: Ratios of Post-Retrofit Stresses to Pre-Retrofit Stresses

\begin{tabular}{|c|c|c|c|}
\hline \multirow{3}{*}{$\begin{array}{c}\text { Compressive } \\
\text { Stresses }\end{array}$} & \multicolumn{3}{|c|}{ Retrofit Scenario } \\
\hline & \multirow[t]{2}{*}{$\begin{array}{c}\mathbf{A} \\
\text { (Case 1-3) }\end{array}$} & \multirow[t]{2}{*}{$\begin{array}{c}\text { B } \\
\text { (Case 1-4) } \\
\end{array}$} & \multirow[t]{2}{*}{$\begin{array}{c}\mathbf{C} \\
\text { (Case 2-4) }\end{array}$} \\
\hline & & & \\
\hline STRENGTH I & 1.63 & 2.46 & 0.96 \\
\hline SERVICE 1 & 1.29 & 1.89 & 0.89 \\
\hline FATIGUE & $22.82^{1}$ & $38.11^{1}$ & 1.27 \\
\hline \multicolumn{4}{|l|}{ Tensile Stresses } \\
\hline STRENGTH I & 1.09 & 1.22 & 0.96 \\
\hline SERVICE 1 & 0.98 & 1.09 & 0.89 \\
\hline FATIGUE & 1.68 & 1.94 & 1.27 \\
\hline
\end{tabular}

It is often assumed, incorrectly, that composite concrete bridge decks replaced by GFRP bridge decks remain fully composite (Scenario A). This fully composite behavior may be exhibited for SERVICE I and FATIGUE load cases. Nonetheless, as discussed in Section 3.4, it is unlikely that composite behavior (Case 3) may be achieved for STRENGTH I. Therefore, it is more appropriate and more conservative to assume non-composite behavior (Case 4) and thus retrofit Scenario B. As a result there is an error associated with stresses determined assuming Scenario A when Scenario B is actually appropriate. In this example, compression flange stresses are underestimated by 34\% and tension flange stresses by 11\% under STRENGTH I and 32\% and 10\% under SERVICE I load combinations. FATIGUE stresses are underestimated by $13 \%$.

Due to the significantly reduced dead load of a GFRP deck (DL stresses are reduced by more than half in the example shown), Scenario C, when appropriate, results in reduced stresses on the structure. Although it is noted that Scenario C does have an increased fatigue stress range due to the increased DF used. 


\subsection{AASHTO FATIGUE CRITERIA}

Fatigue loading is a special case and requires particular attention if fatigue-prone details are present. The following discussion addresses the fatigue requirements from AASHTO (2004). Fatigue is defined as a member's tendency to fail at a level of stress below its specified yield stress when subjected to repeated loading. Fatigue cracking generally results from repeated load applications and the resulting cyclic stresses, which result from either a long exposure time or a high frequency of occurrence. Steel cracking and the failures developed as a result of cyclic loading generally show little or no evidence of plastic deformation. Hence, it is often difficult to identify these problems before serious damage or failure occurs in the member (FHWA 2003). Structural details have different levels of resistance to fatigue cracking. Three key factors affecting the fatigue life of a member are:

- Stress Range (S)

- Number of cycles (N)

- Type of Detail

For the example structure, the FATIGUE stress ranges are given in Table 4-6. The number of cycles depends on the roadway carried by the bridge (AASHTO 2004 - Section 6.6.1.2.5). A given detail is defined by assigning it to a category ranging from Category A (best case having little susceptibility to fatigue damage) to Category E' (worst case). These categories are defined in AASHTO (2004) Table 6.6.1.2.5-3. Details sharing the same category usually have comparable fatigue resistance and similar stress concentrations. During the inspection of fracture critical members, the assigned fatigue category can be a reminder of which details are the most critical with respect to fatigue cracking. The categories can also set precedence to which details need to be addressed first. 
AASHTO (2004) defines the nominal fatigue resistance as:

$$
\Delta F=\left(\frac{A}{N}\right)^{1 / 3} \geq \frac{\Delta F_{T H}}{2}
$$

Where $N=(365)(75) n(A D T T)_{S L}$ is the number of truck passages in a 75 year life span;

A = constant based on the fatigue detail considered;

$(\mathrm{ADTT})_{\mathrm{SL}}=$ single lane average daily truck traffic $(\mathrm{ADTT})$;

$\mathrm{n}$ = number of stress range cycles per truck passage ( $\mathrm{n}=1$ for this example); and, $\Delta \mathrm{F}_{\mathrm{TH}}=$ constant amplitude fatigue threshold.

Table 4-8 provides the resulting nominal fatigue resistance for various fatigue categories. In calculating $\Delta \mathrm{F}$, the $\mathrm{ADTT}_{\mathrm{SL}}$ is assumed to be 102 vehicles (ADT $=1700$ with $6 \%$ trucks). Also shown in Table 4-8 are the acceptable details for each of the four cases considered based on the calculated FATIGUE stress range. As can be seen from the table, the original case, Case 1, provides adequate resistance for all but fatigue category E'. When replacing the Case 1 deck with any of the other cases, the stress range increases and the structure is no longer adequate for Category D and Category E fatigue details. Case 4 results in a further increased stress range resulting in all but Categories A, B, and B' being excluded.

An example where a change in fatigue category may be critical is the original SC 655 Bridge itself. The original SC655 Bridge was composed of riveted steel girders. The superstructure of the SC655 Bridge was replaced prior to the installation of the GFRP deck. Had it only been a deck replacement project, increased fatigue stresses may have become a major 
consideration. According to the FHWA, riveted splices are considered a fatigue category D (FHWA 2003). In this hypothetical example, only Case 1, a composite concrete deck, would exhibit the necessary fatigue resistance for H25 live loading.

Table 4-8: AASHTO Fatigue Thresholds

\begin{tabular}{|c|cc|c|c|c|c|}
\hline \multicolumn{2}{|c|}{$\begin{array}{c}\text { AASHTO (2004) Table } \\
\mathbf{6 . 6 . 1 . 2 . 5 - 3}\end{array}$} & $\begin{array}{c}\text { Case 1 - Concrete } \\
\text { Composite }\end{array}$ & $\begin{array}{c}\text { Case 2 - Concrete } \\
\text { Non-composite }\end{array}$ & $\begin{array}{c}\text { Case 3 - GFRP } \\
\text { Composite }\end{array}$ & $\begin{array}{c}\text { Case 4 - GFRP } \\
\text { Non-Composite }\end{array}$ \\
\hline $\begin{array}{c}\text { Detail } \\
\text { Category }\end{array}$ & $\begin{array}{c}\Delta \text { F MPa (ksi) } \\
\text { (Eq. 4.3) }\end{array}$ & $\mathrm{S}=41.6(6.03)$ & $\mathrm{S}=63.4(9.20)$ & $\mathrm{S}=70.0(10.15)$ & $\mathrm{S}=80.7(11.70)$ \\
\hline $\mathrm{A}$ & 143.4 & $(20.8)$ & OK & OK & OK & OK \\
\hline B & 112.4 & $(16.3)$ & OK & OK & OK & OK \\
\hline$B^{\prime}$ & 89.6 & $(13)$ & OK & OK & OK & OK \\
\hline C & 80 & $(11.6)$ & OK & OK & OK & NG \\
\hline$C^{\prime}$ & 80 & $(11.6)$ & OK & OK & OK & NG \\
\hline D & 63.4 & $(9.2)$ & OK & NG & NG & NG \\
\hline E & 50.3 & $(7.3)$ & OK & NG & NG & NG \\
\hline$E^{\prime}$ & 35.9 & $(5.2)$ & NG & NG & NG & NG \\
\hline
\end{tabular}




\subsection{SUMMARY}

As can be seen in this single illustrative example the internal stresses in the bridge superstructure are significantly affected when replacing a concrete deck with a GFRP deck. The more flexible axial behavior of the GFRP deck results in less composite behavior being developed between deck and superstructure; resulting in a correspondingly lower neutral axis location. Similarly, the flexible deck does not permit as much transverse distribution of applied loads resulting in higher loads carried by girders immediate adjacent travel lanes. Finally, particular care must be taken when replacing the deck on a structure that contains fatigue prone details. Even though the dead load is reduced when the retrofit employs a GFRP deck replacing a concrete deck, the live load remains the same. Due to decreased composite action and increased distribution factors, the resulting live load stresses in the supporting girders may increase. Hence, this increased stress range must be considered if fatigue-prone details are present.

When a GFRP deck replaces a concrete deck, it has been shown that superstructure internal stresses may increase; significantly in some cases. Nonetheless, forces on structural elements further along the load path, i.e. bearings, support bents, abutments, columns, and foundations, see a reduction in dead load and are relatively unaffected by the composite behavior of the deck or the distribution factor, which results in a lower stress condition. This may be significant for certain situations, such as an old bridge that is supported on timber piers. 


\subsection{CONCLUSIONS AND RECOMMENDATIONS}

Results from a number of in situ load tests of three steel girder bridges having the same GFRP deck system were used to examine the degree of composite action that may be developed and the transverse distribution of wheel loads that may be assumed for such structures. The following conclusions are made based on the observations of these load tests:

1. In general, the observed effective width is less than that prescribed by AASHTO for a comparable concrete deck.

2. The discrete, rather than continuous nature of the shear connection for a GFRP deck, appears to contribute to the reduced efficiency of the deck.

3. There is an apparent degradation in available composite action, particularly for exterior girders, as measured by a general decrease in apparent effective width over time.

4. The observed moment distribution factors for both the Boyer and SC S655 bridges are greater than the AASHTO-prescribed values for comparable depth concrete decks.

Current design practice treats GFRP deck systems in a manner similar to concrete decks.

The results of this study indicate that this may result in non-conservative design values for the bridge girders. Specifically:

5. The effective width of GFRP deck which may be engaged is lower than that of an equivalent concrete deck. This decrease results from increased horizontal shear lag due to the less stiff axial behavior of the deck (as compared to concrete) and increased vertical shear lag due to the relatively soft in-plane shear stiffness of the GFRP deck. 
6. Increased apparent moment distribution factors, indicating reduced transverse distribution of wheel loads, are observed due to the increased transverse flexibility of the GFRP deck system (as compared to an equivalent concrete deck).

\subsection{RECOMMENDATIONS}

The eventual use of GFRP decks for new bridge construction is unclear. Nonetheless, light-weight GFRP decks are attractive for certain applications such as moving spans (bascules, etc.) and bridges located in remote areas where placing a concrete deck may become impractical. Regardless, the primary application for GFRP decks is thought to be deck replacement. The following recommendations are focused on the use of GFRP decks for deck replacement projects.

Because of their significantly reduced weight and enhanced durability characteristics, GFRP decks offer a very attractive alternative for bridge deck replacement, particularly in cases where the existing bridge superstructure or substructure is structurally deficient. The reduced dead load of the deck may, in some cases, permit removing posting or increasing the rating of a bridge. Additionally, GFRP decks may allow similar enhancements for historic bridges without requiring additional structural retrofit, which may affect the historic fabric of the bridge.

The primary consideration when replacing composite concrete bridge decks using GFRP decks is that the supporting girders will be required to support increased live load stresses. This increase results both from the decreased composite action and increased distribution factors (resulting in decreased transverse distribution of forces). Although the dead load stress will likely be reduced, the live load stress is transient and thus represents the stress range considered for 
fatigue sensitive details. This increased stress range must be considered if fatigue-prone details are present.

The decreased composite action available when a GFRP deck is installed also has the effect of increasing compressive stresses in the steel girder since the neutral axis is effectively lower. As such, compression flange and web region stress conditions change and slenderness and stability effects must be considered. Composite action should not be considered for the STRENGTH (AASHTO 2004) load cases when GFRP decks are used in new construction or to replace concrete decks. Additionally, until significantly more data is made available, the lever rule should be used to determine distribution factors for GFRP decks. These recommendations are felt to be appropriately conservative for GFRP decks. 


\section{APPENDIX A}

\section{SAMPLE CALCULATIONS OF BOYER BRIDGE DISTRIBUTION FACTORS AND EFFECTIVE WIDTH}

The following calculations are presented in support of the discussion and results presented in Chapter 3. The calculations are based on the Boyer Bridge presented in Chapter 2.3. All

calculations are based on data obtained from the field test \#1 (November, 2001). A 1/2” grout haunch was assumed for consistency with Luo (2003).

Properties of the W24x104 girders are given (AISC 2002) as:

$\mathrm{d}=24.1 \mathrm{in}$

$\mathrm{b}=12.8$ in

$\mathrm{t}_{\mathrm{f}}=0.750$ in

$$
\begin{aligned}
& \mathrm{t}_{\mathrm{w}}=0.50 \mathrm{in} \\
& \mathrm{I}_{\mathrm{x}}=3100 \mathrm{in}^{4} \\
& \mathrm{~A}=30.6 \mathrm{in}^{2}
\end{aligned}
$$

$\mathrm{Z}_{\mathrm{X}}=289 \mathrm{in}^{3}$
$\mathrm{~S}_{\mathrm{x}}=258 \mathrm{in}^{3}$
$\mathrm{~F}_{\mathrm{y}}=50 \mathrm{ksi}$ 


\section{Boyer Bridge Effective Width Calculation}

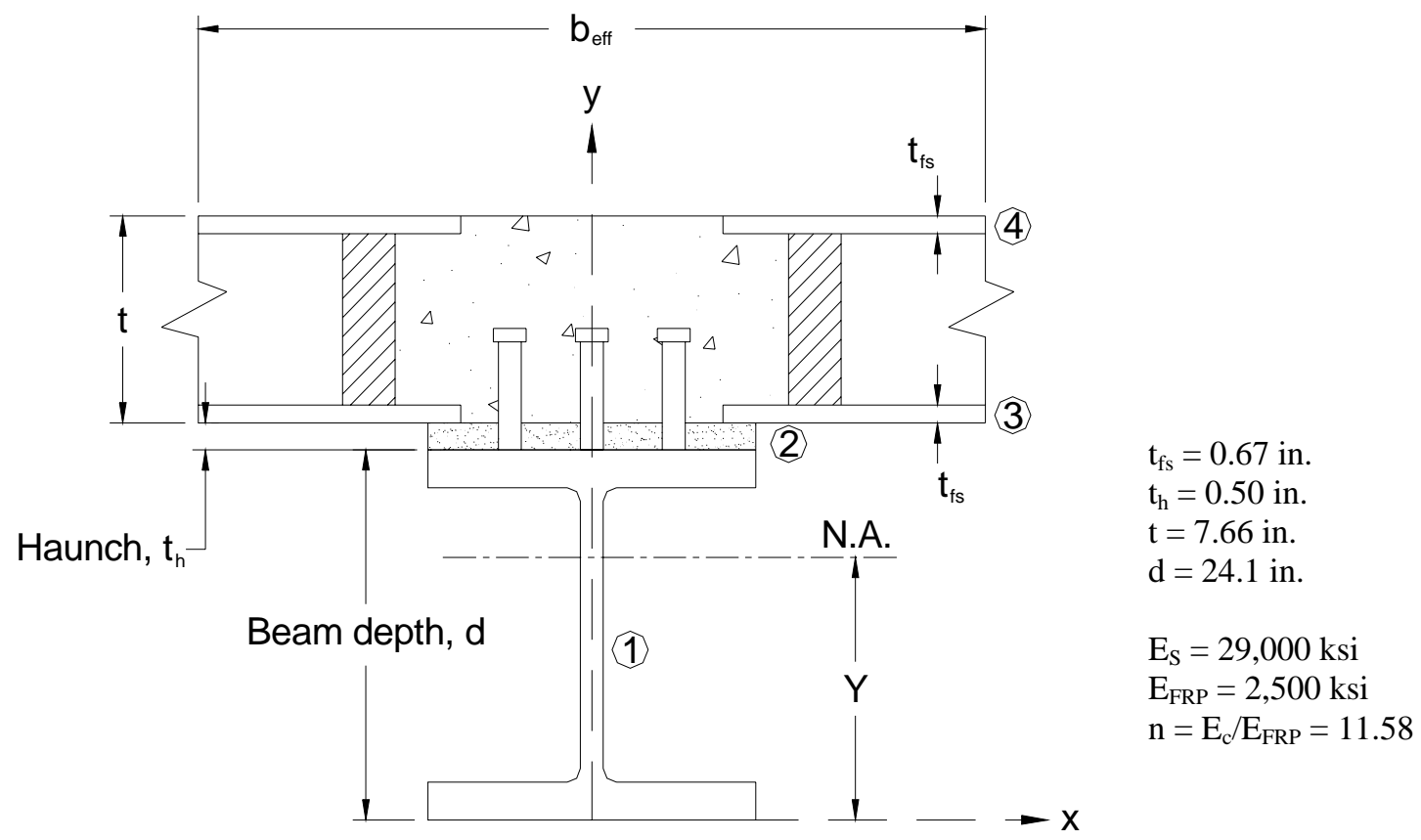

Figure A-1: Cross-section of Composite Beam with GFRP Deck

Table A-1: Effective Width Calculations

\begin{tabular}{|c|c|c|c|}
\hline Element & Area & $\mathbf{y}$ & $\mathbf{y A}$ \\
\hline $\mathbf{1}$ & 30.60 & 12.05 & 368.73 \\
\hline $\mathbf{2}$ & $\frac{12.8 \times 0.5}{8}=0.8$ & 24.35 & 19.48 \\
\hline $\mathbf{3}$ & $\frac{t_{f s} b_{\text {eff }}}{n}=\frac{0.66 b_{\text {eff }}}{11.58}=0.057 \mathrm{~b}_{\text {eff }}$ & 24.93 & $1.42 \mathrm{~b}_{\text {eff }}$ \\
\hline $\mathbf{4}$ & $\frac{t_{f s} b_{\text {eff }}}{n}=\frac{0.66 b_{\text {eff }}}{11.58}=0.057 b_{\text {eff }}$ & 31.93 & $1.82 \mathrm{~b}_{\text {eff }}$ \\
\hline Total & $31.4+0.114 \mathrm{~b}_{\text {eff }}$ & & $388.2+3.24 \mathrm{~b}_{\text {eff }}$ \\
\hline Equilibrium Equation & $\left(31.4+0.114 \mathrm{~b}_{\text {eff }}\right) \bar{y}=388.2+3.24 \mathrm{~b}_{\text {eff }}$ \\
\hline Observed neutral Axis depth, $\bar{y}$ & 14.80 in. \\
\hline Calculated Effective Width, $\mathbf{b}_{\text {eff }}$ & 49.28 in. \\
\hline
\end{tabular}




\section{$\underline{\text { Boyer Bridge Distribution Factor Calculations }}$}

Actual moment distributions observed during load tests may be calculated from consistently-located observed girder strains at a particular section of the bridge:

$$
D F_{\text {girder }_{j}}=\frac{\operatorname{strain}_{j}}{\sum_{\text {all_girders }} \text { strain }}
$$

Table A-2: Measured Bottom Flange Strain Values for Test 1

\begin{tabular}{|c|c|c|c|c|c|}
\hline \multicolumn{7}{|c|}{ Test 1 Position A Bottom Flange } \\
\hline Trial & Beam 1 & Beam 2 & Beam 3 & Beam 4 & Beam 5 \\
\hline A1 & - & - & - & - & - \\
\hline A2 & - & 35.5 & 58.7 & 86.9 & 71.0 \\
\hline A3 & - & 42.1 & 60.3 & 86.9 & 77.1 \\
\hline Avg. & - & $\mathbf{3 8 . 8}$ & $\mathbf{5 9 . 5}$ & $\mathbf{8 6 . 9}$ & $\mathbf{7 4 . 1}$ \\
\hline Dist. Factor & 0 & 0.150 & 0.229 & 0.335 & 0.286 \\
\hline \multicolumn{7}{|c|}{ Test 1 Position B Bottom Flange } \\
\hline Trial & Beam 1 & Beam 2 & Beam 3 & Beam 4 & Beam 5 \\
\hline B1 & 16.8 & 59.8 & 79.4 & 63.6 & 20.6 \\
\hline B2 & 18.7 & 73.8 & 79.9 & 62.2 & 21.5 \\
\hline B3 & - & 79.4 & 80.8 & 64.0 & 24.8 \\
\hline Avg. & $\mathbf{1 7 . 8}$ & $\mathbf{7 1 . 0}$ & $\mathbf{8 0 . 1}$ & $\mathbf{6 3 . 2}$ & $\mathbf{2 2 . 3}$ \\
\hline Dist. Factor & 0.070 & 0.279 & 0.315 & 0.249 & 0.088 \\
\hline \multicolumn{7}{|c|}{ Test 1 Position C Bottom Flange } \\
\hline Trial & Beam 1 & Beam 2 & Beam 3 & Beam 4 & Beam 5 \\
\hline C1 & 74.8 & 89.7 & 51.4 & 23.4 & - \\
\hline C2 & 78.5 & 100.9 & 54.2 & 26.2 & - \\
\hline C3 & 80.4 & 105.6 & 55.1 & 26.2 & - \\
\hline Avg. & $\mathbf{7 7 . 9}$ & $\mathbf{9 8 . 8}$ & $\mathbf{5 3 . 6}$ & $\mathbf{2 5 . 2}$ & - \\
\hline Dist. Factor & 0.305 & 0.387 & 0.210 & 0.099 & 0 \\
\hline \multicolumn{7}{|c|}{ Test 1 Superposition of A\&C Bottom Flange } & \\
\hline Dist. Factor & 0.305 & $\mathbf{0 . 5 3 6}$ & 0.439 & 0.434 & 0.286 \\
\hline
\end{tabular}




\section{APPENDIX B-1}

\section{CALCULATIONS OF BRIDGE SECTIONAL PROPERTIES}

The following calculations are presented in support of the discussion and results presented in

Chapter 4. The prototype structures are based on the South Carolina S655 bridge presented in Chapter 2.4. Four cases were selected to represent the bound of behavior:

Case 1: 8.5 inch thick concrete slab on W36 x 150 girders acting in a fully composite manner

Case 2: 8.5 inch thick concrete slab on W36 x 150 girders having no composite action

Case 3: MMC 7.66 inch GFRP deck on W36 x 150 girders acting in a fully composite manner

Case 4: MMC 7.66 inch GFRP deck on W36 x 150 girders having no composite action

Properties of the W36 x 150 girders are given (AISC 2002) as:

$\mathrm{d}=35.9 \mathrm{in}$

$\mathrm{b}=12.0 \mathrm{in}$

$\mathrm{t}_{\mathrm{f}}=0.940$ in

$$
\begin{aligned}
& \mathrm{t}_{\mathrm{w}}=0.625 \mathrm{in} \\
& \mathrm{I}_{\mathrm{x}}=9040 \mathrm{in}^{4} \\
& \mathrm{~A}=44.2 \mathrm{in}^{2}
\end{aligned}
$$


Case 1: 8.5 inch concrete slab on W36 150 girders acting in a fully composite manner

\section{Composite Section Properties}

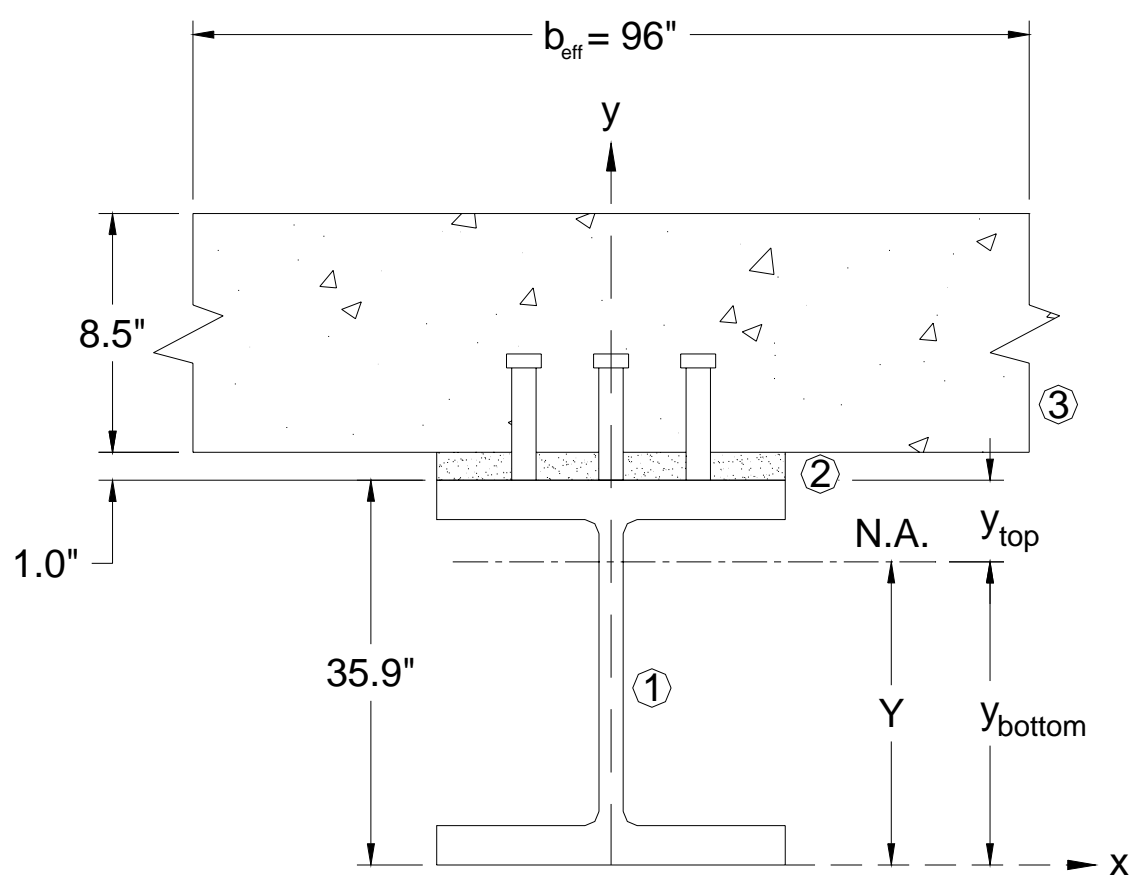

Figure B-1: Cross-section of Composite Beam with Concrete Deck (Case 1)

Table B-1: Composite Section Properties Calculations for Case 1

\begin{tabular}{|c|c|c|c|c|c|c|c|}
\hline Element & $\begin{array}{c}\text { Area } \\
\text { (Transformed) }\end{array}$ & $\mathbf{y}$ & $\mathbf{y A}$ & d & $\mathbf{A d}^{2}$ & $\mathbf{I}_{\mathbf{x}}$ & $\mathbf{I}_{\mathrm{tr}}$ \\
\hline 1 & 44.2 & 17.95 & 793.39 & -16.21 & 11,613 & 9,040 & \\
\hline 2 & 1.5 & 36.40 & 54.60 & 2.24 & 8 & 0 & \\
\hline 3 & 102.0 & 41.15 & 4,197.30 & 6.99 & 4,985 & 614 & \\
\hline \multirow[t]{2}{*}{ Total } & 147.7 & & $5,045.29$ & & 16,605 & 9,654 & 26,260 \\
\hline & $\mathbf{Y}=$ & 34.16 & & & & & \\
\hline
\end{tabular}


Plastic Moment Capacity

Assume plastic neutral axis (PNA) is in slab.

$$
\begin{aligned}
& a=\frac{A_{s} \cdot F_{y}}{0.85 f_{c}^{\prime} \cdot b_{\text {eff }}}=\frac{(44.2)(50)}{0.85(4)(96)}=6.77^{\prime \prime}<t_{s}=8.5^{\prime \prime} \quad \text { PNA in slab...OK } \\
& C=0.85 f_{c}^{\prime} \cdot a \cdot b_{\text {eff }}=0.85(4)(6.77)(96)=2,210 \mathrm{kips} \\
& T=A_{s} \cdot F_{y}=(44.2)(50)=2,210 \mathrm{kips} \\
& e=\frac{d}{2}+t_{\text {grout }}+t_{s}-\frac{a}{2}=\frac{35.9}{2}+1+8.5-\frac{6.77}{2}=24.1 \mathrm{in}
\end{aligned}
$$

\section{Plastic Moment Capacity}

$$
M_{p}=C \cdot e=\frac{(2210)(24.1)}{12}=4,438 \mathrm{kip} \cdot \mathrm{ft}
$$

For W36x150: $\frac{h}{t_{w}}=51.9$

$$
3.76 \sqrt{E / F_{y}}=3.76 \sqrt{29,000 / 50}=90.5 \geq \frac{h}{t_{w}}=51.9
$$

Case 2: 8.5 inch concrete slab on $W 36 \times 150$ girders having no composite action and Case 4: MMC 7.66 inch GFRP deck on W36 x 150 girders having no composite action

$$
\begin{aligned}
& I_{x}=9,040 \mathrm{in}^{4} \quad Z_{x}=581 \mathrm{in}^{3} \\
& M_{p}=Z_{x} F_{y}=2,421 \mathrm{kip} \cdot \mathrm{ft}
\end{aligned}
$$


Case 3: MMC GFRP deck on W36 $x 150$ girders acting in a fully composite manner

\section{Composite Section Properties}

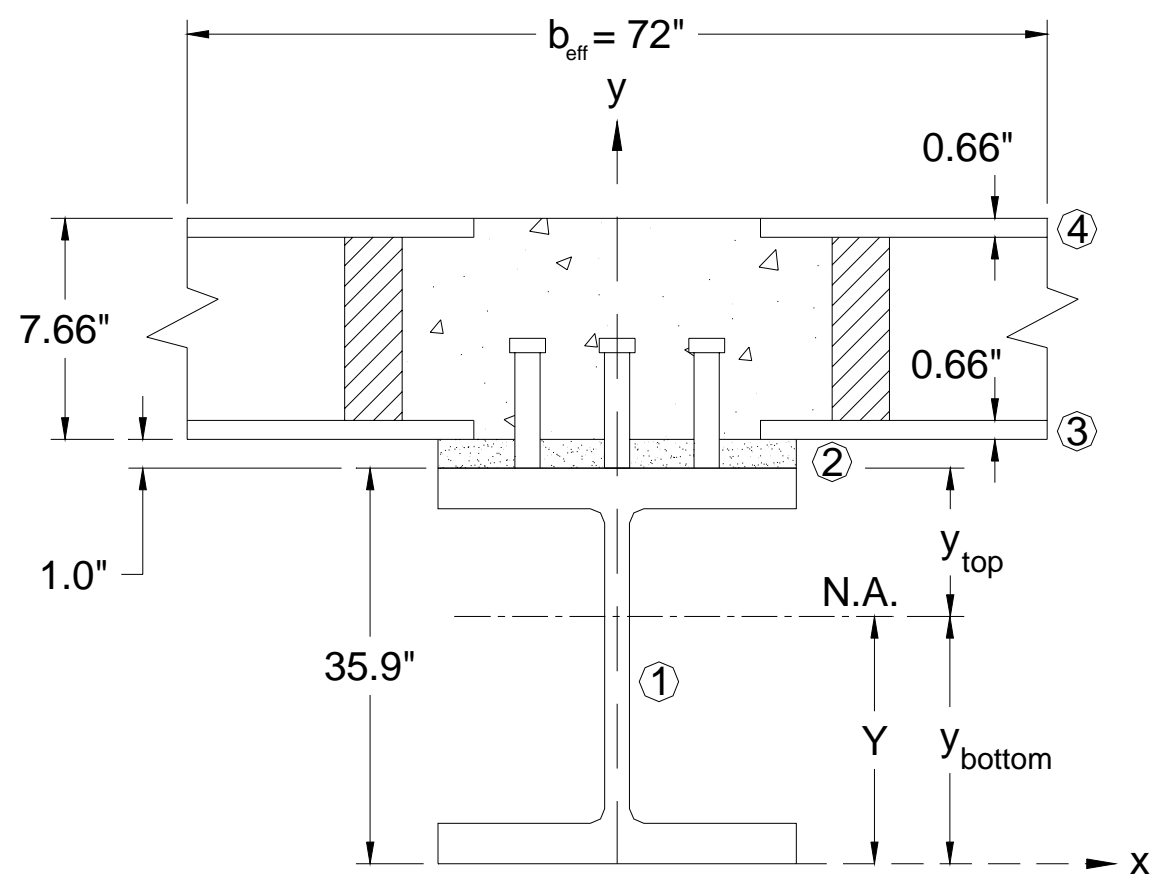

Figure B-2: Cross-section of Composite Beam with GFRP Deck (Case 2)

Table B-2: Composite Section Property Calculations for Case 3

\begin{tabular}{|c|c|c|c|c|c|c|c|}
\hline Element & $\begin{array}{c}\text { Area } \\
\text { (Transformed) }\end{array}$ & $\mathbf{y}$ & $\mathbf{y A}$ & d & $\mathbf{A d}^{2}$ & $\mathbf{I}_{\mathbf{x}}$ & $\mathbf{I}_{\mathbf{x}}$ \\
\hline 1 & 44.2 & 17.95 & 793.39 & -3.29 & 478 & 9,040 & \\
\hline 2 & 1.5 & 36.40 & 54.60 & 15.16 & 345 & 0 & \\
\hline 3 & 3.1 & 37.23 & 117.16 & 15.99 & 805 & 0 & \\
\hline 4 & 3.1 & 44.23 & 139.19 & 22.99 & 1,663 & 0 & \\
\hline \multirow[t]{2}{*}{ Total } & 52.0 & & $1,104.35$ & & 3,291 & 9,040 & 12,332 \\
\hline & $\mathbf{Y}=$ & 21.24 & & & & & \\
\hline
\end{tabular}

Plastic Moment Capacity (see Section 4.1.1) 


\section{APPENDIX B-2}

\section{CALCULATIONS OF APPLIED BRIDGE LOADING}

The following calculations are presented in support of the discussion and results presented in

Chapter 4. The prototype structures are based on the South Carolina S655 bridge presented in Chapter 2.4. Four cases were selected to represent the bound of behavior:

Case 1: 8.5 inch thick concrete slab on W36 x 150 girders acting in a fully composite manner

Case 2: 8.5 inch thick concrete slab on W36 x 150 girders having no composite action

Case 3: MMC 7.66 inch GFRP deck on W36 x 150 girders acting in a fully composite manner

Case 4: MMC 7.66 inch GFRP deck on W36 x 150 girders having no composite action

Properties of the W36 x 150 girders are given (AISC) as:
$\mathrm{d}=35.9$ in
$\mathrm{t}_{\mathrm{w}}=0.625$ in
$\mathrm{I}_{\mathrm{x}}=9040 \mathrm{in}^{4}$
$\mathrm{A}=44.2 \mathrm{in}^{2}$
$\mathrm{Z}_{\mathrm{x}}=581 \mathrm{in}^{3}$
$\mathrm{S}_{\mathrm{x}}=504 \mathrm{in}^{3}$
$\mathrm{F}_{\mathrm{y}}=50 \mathrm{ksi}$
$\mathrm{t}_{\mathrm{f}}=0.940$ in

All loading calculations are consistent with the 2004 AASHTO LRFD Bridge Design Specifications.

\section{Dead Load of Prototype Structures}

Dead Load of Components (DC)

Effective width of slab $=\mathrm{S}=96$ in. $=8 \mathrm{ft}$

8.5 in. concrete slab: $\frac{\left(8^{\prime}\right)\left(8.5^{\prime \prime}\right)\left(0.150 \mathrm{k} / \mathrm{ft}^{3}\right)}{(12 \mathrm{in} / \mathrm{ft})}=0.850 \mathrm{k} / \mathrm{ft}$ see Chapter 1.3.1

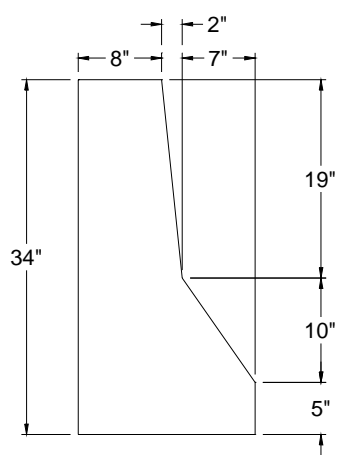


MMC 7.66 in. GFRP panel: $\left(8^{\prime}\right)\left(0.020 \mathrm{k} / \mathrm{ft}^{2}\right)=0.160 \mathrm{k} / \mathrm{ft}$

Concrete parapet (equally distributed to all girders):

$$
\begin{aligned}
& \text { Area }=\left(8^{\prime \prime} \cdot 34 "\right)+\left(.5 \cdot 2^{\prime \prime} \cdot 19^{\prime \prime}\right)+\left(10 " \cdot \frac{2^{\prime \prime}+9 "}{2}\right)+\left(9^{\prime \prime} \cdot 5^{\prime \prime}\right)=391 \mathrm{in}^{2} \\
& w t .=\left(\frac{2 \text { parapets }}{5 \text { girders }}\right)\left(391 \mathrm{in}^{2}\right)\left(\frac{1 \mathrm{ft}}{12 \mathrm{in}}\right)^{2}\left(0.150 \mathrm{k} / \mathrm{ft}^{3}\right)=0.163 \mathrm{k} / \mathrm{ft}
\end{aligned}
$$

Diaphragms (MC18x42.7): $\frac{\left(\frac{2 \text { diaphragms }}{\text { beam }}\right)(0.0427 \mathrm{k} / \mathrm{ft})\left(8^{\prime}\right)}{57.5^{\prime}}=0.012 \mathrm{k} / \mathrm{ft}$

Girder self-weight (W36x150): $=0.150 \mathrm{k} / \mathrm{ft}$

Case 1 and Case 2: $D C=(0.850 k / f t)+(0.163 k / f t)+(0.012 k / f t)+(0.150 k / f t)=1.175 k / f t$

Case 3 and Case 4: $D C=(0.160 \mathrm{k} / \mathrm{ft})+(0.163 \mathrm{k} / \mathrm{ft})+(0.012 \mathrm{k} / \mathrm{ft})+(0.150 \mathrm{k} / \mathrm{ft})=0.485 \mathrm{k} / \mathrm{ft}$

\section{Dead Load of Wearing Surface (DW)}

All cases: $D W=\frac{\left(1.5^{\prime \prime}\right)\left(8^{\prime}\right)\left(0.140 \mathrm{k} / \mathrm{ft}^{3}\right)}{12^{\mathrm{in} / \mathrm{ft}}}=0.150 \mathrm{k} / \mathrm{ft}$ 
$\underline{\text { Live Loads (LL) }}$

\section{H20 Loading:}

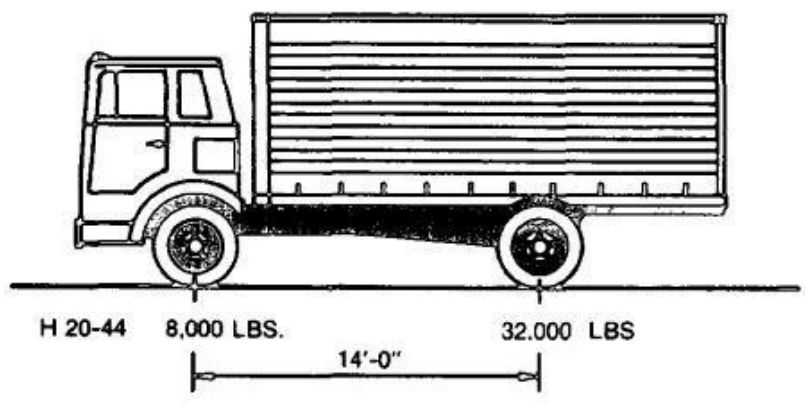

(AASHTO 2004)

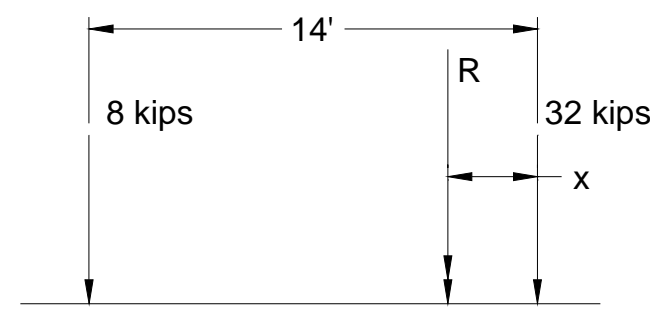

$\Sigma M_{x}=-8 \cdot(14-x)+32 x=0 \rightarrow x=2.8 f t$

therefore, for maximum moment position H20 rear axle@x/2=1.4’ to the right of midspan.
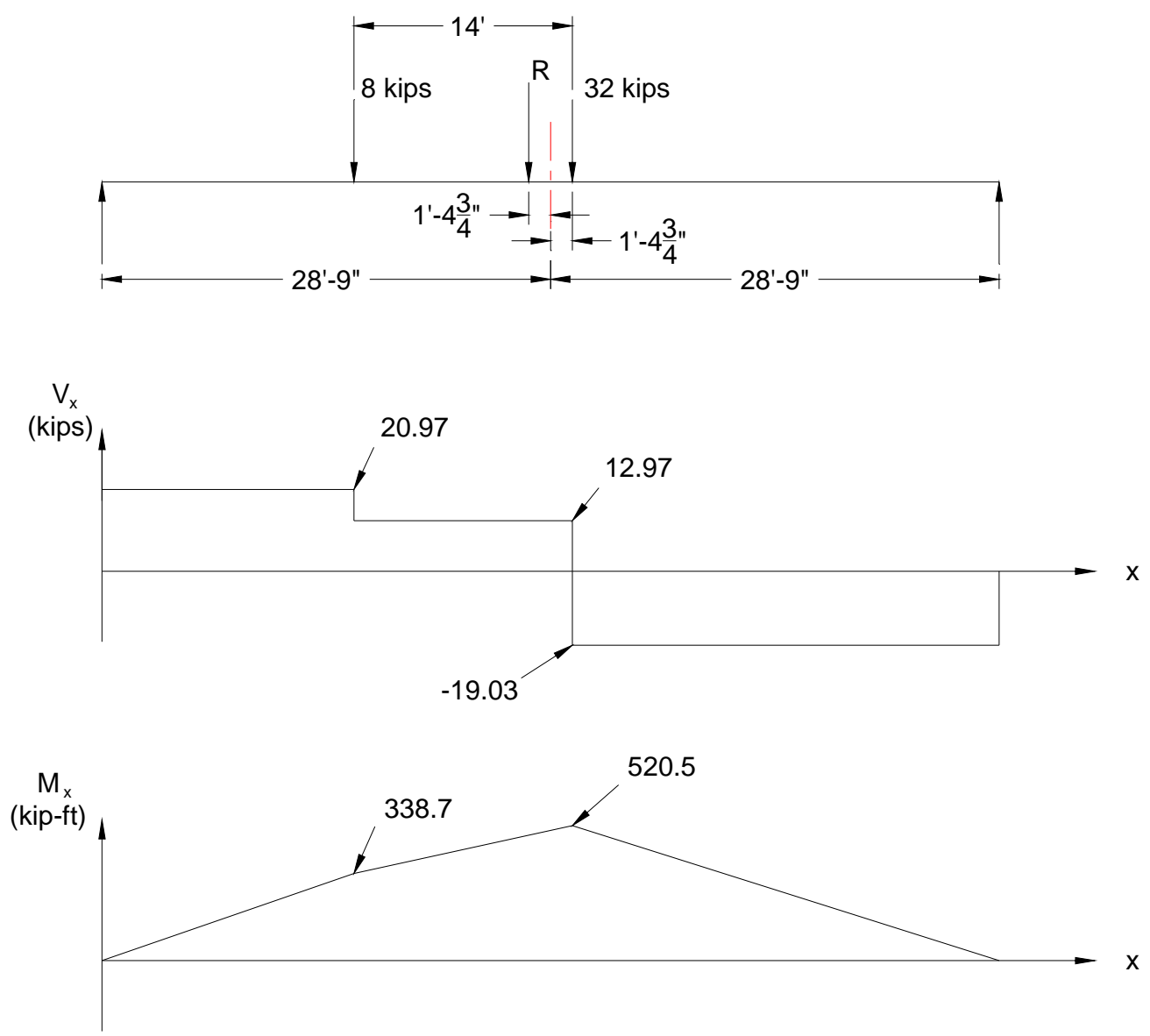

Max H20 LL Moment $=520.5 \mathrm{kip}-\mathrm{ft}$

Max H25 LL Moment = 1.25 x $520.5=650.6$ kip-ft 


\section{Dead Load Moments:}

Cases 1 and 2:

Max DC Moment: $M_{D C}=\frac{w l^{2}}{8}=\frac{(1.175)(57.5)^{2}}{8}=485.6 \mathrm{kip} \cdot \mathrm{ft}$

Max DW Moment: $M_{D W}=\frac{w l^{2}}{8}=\frac{(0.150)(57.5)^{2}}{8}=62.0 \mathrm{kip} \cdot \mathrm{ft}$

Cases 3 and 4:

Max DC Moment: $M_{D C}=\frac{w l^{2}}{8}=\frac{(0.485)(57.5)^{2}}{8}=200.4 \mathrm{kip} \cdot f t$

Max DW Moment: $M_{D W}=\frac{w l^{2}}{8}=\frac{(0.150)(57.5)^{2}}{8}=62.0 \mathrm{kip} \cdot \mathrm{ft}$

As per AASHTO LRFD 2004, the Moment Distribution Factor (DF) for Normal Distribution is:

\section{Cases 1 and 2:}

$D F=0.688$

Therefore the unfactored H25 LL moment for each girder is:

$M_{L L}=0.688 \cdot(650.6 \mathrm{kip} \cdot \mathrm{ft}) \rightarrow M_{L L}=447.6 \mathrm{kip} \cdot \mathrm{ft}$

\section{Cases 3 and 4:}

$D F=0.875$ lever rule

Therefore the unfactored H25 LL moment for each girder is:

$$
M_{L L}=0.875 \cdot(650.6 \mathrm{kip} \cdot \mathrm{ft}) \rightarrow M_{L L}=569.3 \mathrm{kip} \cdot \mathrm{ft}
$$

The STRENGTH I factored moment is:

$M_{U}=1.75 \cdot\left(1.33 \cdot M_{L L}\right)+1.25 \cdot M_{D C}+1.5 \cdot M_{D W}$

\section{Cases 1 and 2:}

$$
\begin{aligned}
& M_{U}=1.75 \cdot(1.33 \cdot 447.6 \mathrm{kip} \cdot \mathrm{ft})+1.25 \cdot(485.6 \mathrm{kip} \cdot \mathrm{ft})+1.5 \cdot(62.0 \mathrm{kip} \cdot \mathrm{ft}) \\
& \rightarrow M_{U}=1741.8 \mathrm{kip} \cdot \mathrm{ft}
\end{aligned}
$$


Case 3 and Case 4:

$$
\begin{aligned}
& M_{U}=1.75 \cdot(1.33 \cdot 569.3 \mathrm{kip} \cdot \mathrm{ft})+1.25 \cdot(200.4 \mathrm{kip} \cdot \mathrm{ft})+1.5 \cdot(62.0 \mathrm{kip} \cdot \mathrm{ft}) \\
& \rightarrow M_{U}=1668.5 \mathrm{kip} \cdot \mathrm{ft}
\end{aligned}
$$

The SERVICE I factored moment is:

$$
M_{U}=1.00 \cdot\left(1.33 \cdot M_{L L}\right)+1.00 \cdot M_{D C}+1.00 \cdot M_{D W}
$$

\section{Cases 1 and 2:}

$$
\begin{aligned}
& M_{U}=1.00 \cdot(1.33 \cdot 447.6 \mathrm{kip} \cdot \mathrm{ft})+1.00 \cdot(485.6 \mathrm{kip} \cdot \mathrm{ft})+1.00 \cdot(62.0 \mathrm{kip} \cdot \mathrm{ft}) \\
& \rightarrow M_{U}=1142.9 \mathrm{kip} \cdot \mathrm{ft}
\end{aligned}
$$

\section{Case 3 and Case 4:}

$$
\begin{aligned}
& M_{U}=1.00 \cdot(1.33 \cdot 569.3 \mathrm{kip} \cdot \mathrm{ft})+1.00 \cdot(200.4 \mathrm{kip} \cdot \mathrm{ft})+1.00 \cdot(62.0 \mathrm{kip} \cdot \mathrm{ft}) \\
& \rightarrow M_{U}=1019.6 \mathrm{kip} \cdot \mathrm{ft}
\end{aligned}
$$

The FATIGUE factored moment range is:

$$
M_{U}=0.75 \cdot\left(1.15 \cdot M_{L L}\right)
$$

\section{Cases 1 and 2:}

$$
\begin{aligned}
& M_{U}=0.75 \cdot(1.15 \cdot 447.6 \mathrm{kip} \cdot \mathrm{ft}) \\
& \rightarrow M_{U}=386.1 \mathrm{kip} \cdot \mathrm{ft}
\end{aligned}
$$

\section{Cases 3 and 4:}

$$
\begin{aligned}
& M_{U}=0.75 \cdot(1.15 \cdot 569.3 \mathrm{kip} \cdot \mathrm{ft}) \\
& \rightarrow M_{U}=491.0 \mathrm{kip} \cdot \mathrm{ft}
\end{aligned}
$$




\section{BIBLIOGRAPHY}

AASHTO, 2004. AASHTO LRFD Bridge Design Specifications, $3^{\text {rd }}$ Edition, American Association of State Highway and Transportation Officials, Washington, D.C.

AASHTO, 1996. Standard Specifications for Highway Bridges $16^{\text {th }}$ edition. American Association of State Highway and Transportation Officials, Washington DC.

American Composites Manufacturers Association (ACMA) 2004. Global FRP Use for Bridge Applications: Vehicular Bridges. http://www.mdacomposites.org/mda/Bridge_Report_VEH.htm

American Institute of Steel Construction (AISC) 2002. Manual of Steel Construction, Load and Resistance Factor Design, $3^{\text {rd }}$ Ed. American Institute of Steel Construction, Chicago.

BDI, 2003. Load Testing and Rating Report Update, Fairground Road Bridge, Greene County., Ohio, Bridge Diagnostics Inc., Boulder, Colorado.

Black, S. 2003. How are Composite Bridges Performing? Composites Technology, December 2003, pp 16-22.

Chandrashekhara, K. and Nanni, A. 2000. Experimental Testing and Modeling of a GFRP Bridge. Report of the Missouri Department of Transportation, Research, Development and Technology Report No. RI 98-032.

Crocker, H., Shehata, E., Haldane-Wilson, R. and Mufti A. 2002. Innovative Fibre Reinforced Bridge Deck Modules. Proceedings of the $3^{\text {rd }}$ International Conference on Composites in Infrastructure, San Francisco, CA. Paper \# 76.

Drexler, A. 2005. Broadway Bridge Deck Panel Testing Report. Portland State University, Portland Oregon.

Eom, J. and Nowak, A. 2001. Live Load Distribution for Steel Girder Bridges. ASCE Journal of Bridge Engineering, Vol. 6, No. 6, pp 489-497.

Federal Highway Administration (FHWA) 2004. Deficient Bridges by State and Highway System, US Department of Transportation.

Federal Highway Administration (FHWA) 2003. Fracture Critical Inspection Techniques for Steel Bridges, US Department of Transportation. 
GangaRao, H., Thippeswamy, H. K., Shekar, V. and Craigo, C. 1999. "Development of Glass Fiber Reinforced Polymer Composite Bridge Deck.” SAMPE Journal, Vol. 35, No. 4, pp. 12-15.

Hooks, J., and O'Connor, J., 2004. A Summary of Six Years Experience Using GFRP Composites for Bridge Decks, Proceedings of the $21^{\text {st }}$ International Bridge Conference, June 1214, 2004, Pittsburgh, PA.

Keelor, D.C., Luo, V., Earls, C.J., and Yulismana, W. 2004. Service Load Effective Compression Flange Width in GFRP Deck Systems Acting Compositely with Steel Stringers, ASCE Journal of Composites for Construction, Vol. 8, No. 4, pp. 289-197.

Keller, T and Gurtler, H. 2005. Composite Action and Adhesive Bond Between Fiber-Reinforced Polymer Bridge Decks and Main Girders, ASCE Journal of Composites for Construction, Vol. 9, No. 4, pp. 360-368.

Keller, T., Gurtler, H. and Zhou, A. 2004. Performance of Adhesively Bonded GFRP Deck and Steel Bridge Girders, Proceedings of the Fourth Conference on Advanced Composite Materials in Bridges and Structures, Calgary, Canada, July 2004. Paper Number 076.

Luo, Y. 2003. The Composite Response Assessment of the Steel Beam-FRP Deck System in the Boyer Bridge, MS Thesis, University of Pittsburgh, Pittsburgh, Pennsylvania.

Martin Marietta Composites (MMC) 2001. Duraspan Fiber-reinforced Polymer (FRP) Bridge Deck Technical Literature.

Moon, F.L., Eckel, D.A. and Gillespie, J.W., 2002. Shear Stud Connection for the Development of Composite Action Between Steel Girders and Fiber-Reinforced Polymer Bridge Decks, ASCE Journal of Structural Engineering, Vol. 128, No. 6, pp 762-770.

Moses, J., Harries, K., Earls, C., and Yulismana, W. 2005. Evaluation of Effective Width and Distribution Factors for GFRP Bridge Decks Supported on Steel Girders, ASCE Journal of Bridge Engineering. (in press).

Motley, D. R., Castanos, S. A., Klang, E. C. and Richards, D. 2002. Effects of Diagonal Webs in GFRP Bridge Decks. Proceedings of the $3^{\text {rd }}$ International Conference on Composites in Infrastructure, San Francisco, CA. Paper \# 34.

National Bridge Inventory (NBI), 2003. http://www.nationalbridgeinventory.com, accessed March 14, 2005.

Turner, K.M., 2003. In situ Evaluation of Demonstration GFRP Bridge Deck System Installed on South Carolina Route S655. M.S. Thesis, Department of Civil and Environmental Engineering, University of South Carolina. August 2003. 202 pp.

Turner, K.M., Harries, K.A. Petrou, M.F. and Rizos, D. 2004. In-situ Structural Evaluation of GFRP Bridge Deck System. Journal of Composite Structures, Vol. 65 No. 2 pp. 157-165. 
Turner, K., Harries, K.A. and Petrou, M.F. 2003. In-situ Structural Evaluation of GFRP Bridge Deck System. Proceedings of the $82^{\text {nd }}$ Annual Meeting of the Transportation Research Board, Washington DC, January 2003.

Yulismana, W., 2005. Experimental Study of the Behavior of Fiber Reinforced Polymer Bridge Deck System, Ph.D. Dissertation, University of Pittsburgh, Pittsburgh, Pennsylvania.

Zhou, A., Lesko, J. J., Coleman, J. T. and Cousins T. E. 2002. Failure Modes and Failure Mechanisms of Fiber Reinforced Polymer Composite Bridge Decks. Proceedings of the $3^{\text {rd }}$ International Conference on Composites in Infrastructure, San Francisco, CA. Paper \# 63.

Zokaie, T., Imbsen, R, Osterkamp, T., and Wong, T. (1992) Distribution of Wheel Loads on Highway Bridges, NCHRP Project 12-26, National Cooperative Highway Research Program, Washington, D.C. 